UNIVERSIDADE DE SÃO PAULO

FACULDADE DE ECONOMIA, ADMINISTRAÇÃO E CONTABILIDADE DEPARTAMENTO DE ADMINISTRAÇÃO

PROGRAMA DE MESTRADO PROFISSIONAL EM

EMPREENDEDORISMO

JULIANA HARUMI FUJISAWA CAMPOS

INOVAÇÃO E MODELO DE NEGÓCIOS COMO FERRAMENTAS COMPETITIVAS EM GRANDES EMPRESAS

São Paulo 
Prof. Dr. Marco Antonio Zago

Reitor da Universidade de São Paulo

Prof. Dr. Adalberto Américo Fischmann

Diretor da Faculdade de Economia, Administração e Contabilidade

Prof. Dr. Roberto Sbragia

Chefe do Departamento de Administração

Prof. Dr. Martinho Isnard Ribeiro de Almeida

Coordenador do Programa de Mestrado Profissional em Empreendedorismo 
JULIANA HARUMI FUJISAWA CAMPOS

\section{INOVAÇÃO E MODELO DE NEGÓCIOS COMO FERRAMENTAS COMPETITIVAS EM GRANDES EMPRESAS}

\section{Versão Corrigida}

Dissertação apresentada ao Programa de Mestrado Profissional em Empreendedorismo, do Departamento de Administração, da Faculdade de Economia, Administração e Contabilidade da Universidade de São Paulo, como requisito parcial para a obtenção do título de Mestre em Ciência.

Orientadora: Profa. Dra. Jane A. Marques

São Paulo 
Autorizo a reprodução e divulgação total ou parcial deste trabalho, por qualquer meio convencional ou eletrônico, para fins de estudo e pesquisa, desde que citada a fonte.

\section{FICHA CATALOGRÁFICA}

Elaborada pela Seção de Processamento Técnico do SBD/FEA/USP

Campos, Juliana Harumi Fujisawa

Inovação e modelo de negócios como ferramentas competitivas em grandes empresas / Juliana Harumi Fujisawa Campos. - São Paulo, 2017.

$93 \mathrm{p}$.

Dissertação (Mestrado) - Universidade de São Paulo, 2017.

Orientador: Jane A. Marques.

1. Inovação 2. Modelo de negócios 3. Gestão da inovação 4. Competitividade I. Universidade de São Paulo. Faculdade de Economia, Administração e Contabilidade. II. Título.

$\mathrm{CDD}-658.4$ 
À minha filha, Cecilia, por trazer mais alegria à minha vida. 



\section{AGRADECIMENTOS}

Aos meus pais por incentivarem os estudos.

À minha família e amigos por acreditarem.

À minha orientadora, Profa. Dra. Jane A. Marques, pela dedicação e orientação.

Aos colegas de mestrado pela troca de experiências e risadas.

Aos membros docentes pelo conhecimento compartilhado.

Aos entrevistados pela disponibilidade em participar da pesquisa.

Aos colegas de trabalho pelo companheirismo.

E, especialmente, ao meu marido Eric e à minha filha Cecilia pelo apoio e compreensão. 

What got you here won't get you there

(O que te trouxe até aqui não é o que vai te levar até lá)

Marshall Goldsmith 2009 



\section{RESUMO}

O propósito desta dissertação é entender como grandes empresas multinacionais desenvolvem modelo de negócios suportados por suas inovações, visando a manter a competitividade e a atender às necessidades de seus consumidores em um mercado cada vez mais dinâmico e exigente. Para tal fim, definiu-se como objetivo principal compreender a maneira como especialistas que trabalham em grandes empresas inovam e desenvolvem modelos de negócios para atender às demandas de mercado, visando à competitividade e à sobrevivência do negócio. A escolha deste tema se justifica pelo fato de que empresas grandes possuem maior dificuldade de inovar, pois continuam a fazer melhor o que as tornaram grande, priorizando a eficiência e execução à inovação. Trata-se de um estudo exploratório de natureza qualitativa, baseado em fontes primárias por meio de entrevistas em profundidade com doze especialistas que atuam com inovação em grandes empresas multinacionais. Para a composição amostral, os especialistas foram buscados em organizações multinacionais com base em três rankings de inovação existentes no país que distinguem as melhores empresas nesse quesito. A análise identificou que há um alinhamento entre teoria e prática no que tange aos conceitos de inovação e a modelo de negócios. Além disso, constatou-se que os especialistas abordam a inovação de forma estratégica e estruturada, desenvolvendo assim diferentes tipos de inovação: tecnológica, incremental, radical e disruptiva. No entanto, apenas as inovações ditas como radicais ou disruptivas criaram modelos de negócios nas empresas dos especialistas entrevistados, por diferentes motivos, a saber: pela característica da indústria; pelo direcional estratégico da organização; ou pelo papel da liderança, sendo este fundamental para fomentar a prática de inovação e eliminar barreiras estruturais ou comportamentais presentes. Desta forma, o estudo exploratório trouxe à luz a importância da inovação em relação à sua prática e à implantação no ambiente de negócios, bem como seu valor para a competitividade empresarial quanto ao desenvolvimento de modelo de negócios.

Palavras-chave: Inovação. Gestão da inovação. Modelo de negócios. Competitividade. 



\begin{abstract}
The purpose of this thesis is to understand how large multinational companies develop a business model supported by their innovations in order to maintain their competitiveness and to meet consumers' needs in an increasingly dynamic and demanding market. Therefore, the main objective was to understand how specialists who work in large companies innovate and develop business models to meet market demands, aiming competitiveness and business survival. The choice of this theme is justified by the fact that large companies have more difficulty to innovate, as they continue to do better what has made them big, by prioritizing efficiency and execution over innovation. It is an exploratory and qualitative study based on primary data sources and in-depth interviews with twelve specialists who work with innovation in large multinational companies. For the sample composition, experts were selected in multinational companies based on three local innovation rankings that distinguishes the best companies in this area. The analysis identified that there is an alignment between theory and practice in terms of innovation concepts and business models. In addition, all the companies surveyed approach innovation in a strategic and structured way, developing different types of innovation - technological, incremental, radical, and disruptive. However, only radical or disruptive innovations have created business models in the surveyed companies, for different reasons: either because of the characteristics of the industry; by the strategic direction of the organization; or by the role of leadership, the latter being fundamental to foster innovation practices and to eliminate structural or behavioral barriers presented. Thus, the exploratory study has brought to light the importance of innovation in relation to its practice and to its implementation in business environment, as well as its value for business competitiveness concerning the development of business models.
\end{abstract}

Keywords: Innovation. Innovation management. Business models. Competitiveness. 



\section{LISTA DE SIGLAS}

BM\&FBOVESPA Bolsa de Mercadorias \& Futuros (BM\&F) e Bolsa de Valores de São Paulo

BNDES Banco Nacional de Desenvolvimento Econômico e Social

B2B Business to Business

B2C Business to Consumer

CEO Chief Executive Officer (Diretor Executivo)

CNI Confederação Nacional da Indústria

FINEP Financiadora de Estudos e Projetos

IEL Instituto Euvaldo Lodi

ISO International Organization for Standardization

(Organização Internacional de Normalização)

MBA Master Business Administration

MBC Movimento Brasil Competitivo

MCTIC Ministério de Ciência, Tecnologia, Inovação e Comunicação

MEI Mobilização Empresarial da Inovação

OCDE Organização para a Cooperação e Desenvolvimento Econômico

P\&D Pesquisa e Desenvolvimento

SEBRAE Serviço Brasileiro de Apoio às Micro e Pequenas Empresas

SENAI Serviço Nacional de Aprendizagem Industrial 



\section{LISTA DE FIGURAS}

Figura 1 - Dinâmica da inovação entre diferentes setores 24

Figura 2 - Estrutura do presente estudo 27

Figura 3 - Estrutura do referencial teórico. 29

Figura 4 - Modelo de programas de inovação fechada ............................................................. 31

Figura 5 - Modelo de programa de inovação aberta ............................................................... 32

Figura 6 - Comparação da segunda geração do processo de Stage-Gates com o que pode parecer o processo de terceira geração .................................................................................. 34

Figura 7 - Modelo Temaguide de Inovação ............................................................................... 35

Figura 8 - Estrutura da gestão do processo de inovação .......................................................... 36

Figura 9 - Representação do processo de inovaçãa simplificado ............................................36

Figura 10 - Processo de inovação de produto descontinuado...................................................37

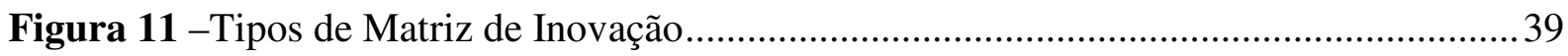

Figura 12 - Impacto da mudança tecnológica de sustentação e de ruptura............................. 40

Figura 13 - Relação entre modelo de negócios e estratégia de uma empresa.........................43

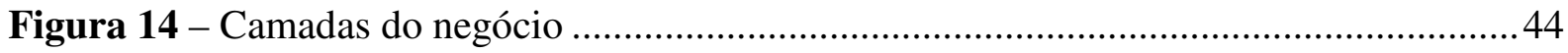

Figura 15 - A estrutura 4I's: Fases do processo de inovação de modelo de negócios e seus

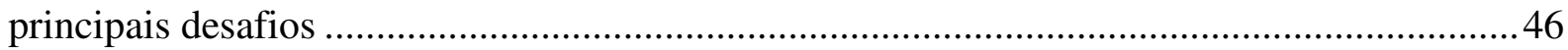

Figura 16 - Elementos de um modelo de negócios bem-sucedido .....................................47

Figura 17 - Características de um modelo de negócios .....................................................48

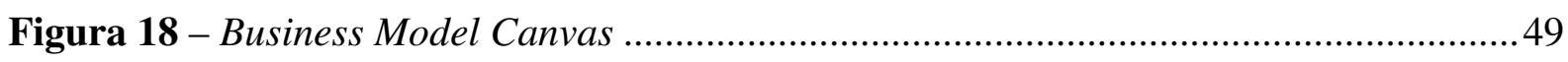

Figura 19 - Procedimentos metodológicos do presente estudo.............................................53

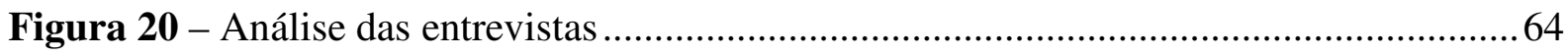

Figura 21 - Fatores de modelo de negócios por meio da inovação........................................84 



\section{LISTA DE QUADROS}

Quadro 1 - Resumo das ideias principais sobre inovação 42

Quadro 2 - Resumo das principais ideias sobre a teoria de modelos de negócios 51

Quadro 3 - Protocolo de Pesquisa 55

Quadro 4 - Matriz de Amarração Metodológica 56

Quadro 5 - Matriz de amarração simplificada. 57

Quadro 6 - Classificação de grande empresa em função da renda operacional bruta anual...58 Quadro 7 - Relação das empresas selecionadas para análise e quantidade de prêmios que cada qual recebeu entre 2011 e 2013 60

Quadro 8-Características dos especialistas entrevistados e das respectivas multinacionais para as quais trabalham 62

Quadro 9 - Prática versus teoria: conceito de inovação. 66

Quadro 10 - Número de especialistas engajados com inovação e com os modelos de negócios, em função do tempo 67

Quadro 11 - Prática versus teoria: conceito de modelos de negócios 69

Quadro 12 - Prática versus teoria: processo de inovação 72 



\section{SUMÁRIO}

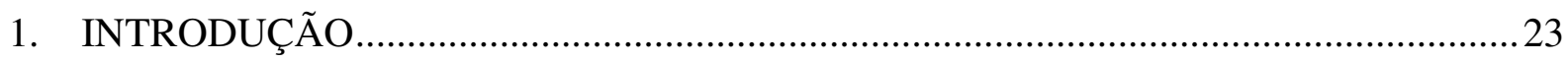

1.1 RELATO: DEFINIÇÃO DA SITUAÇÃO-PROBLEMA .................................................. 24

1.2 PROBLEMA DE PESQUISA, OBJETIVOS E ESTRUTURAÇÃO DO TRABALHO.... 26

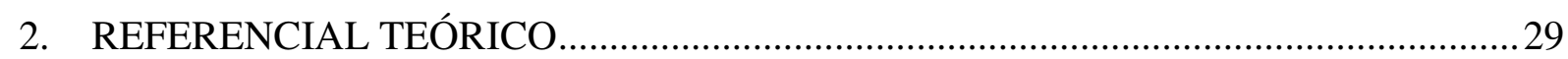

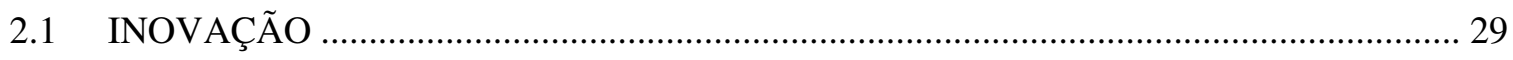

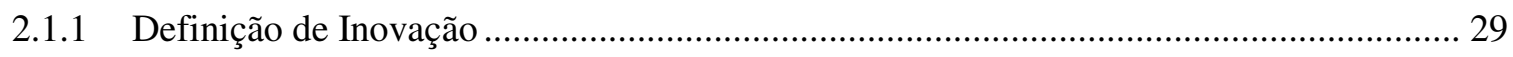

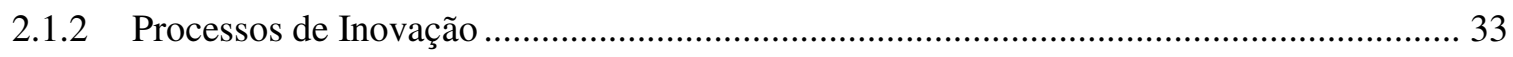

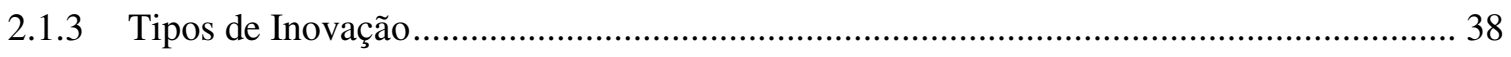

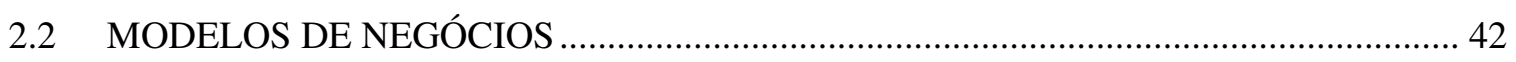

2.2.1 Definição de Modelos de Negócios ..................................................................................... 42

2.2.2 Desenvolvimento de Modelos de Negócios................................................................... 45

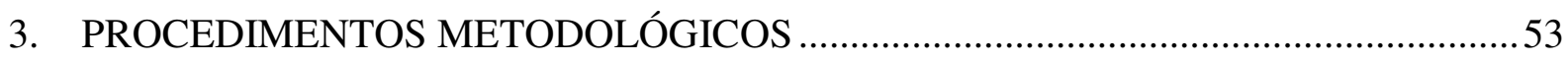

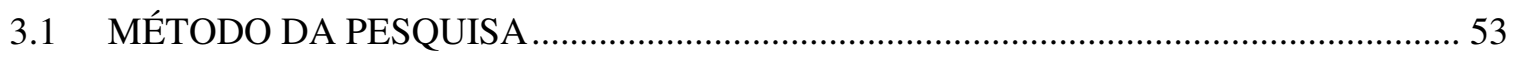

3.2 PREPARAÇÃO PARA A PESQUISA DE CAMPO ...................................................... 54

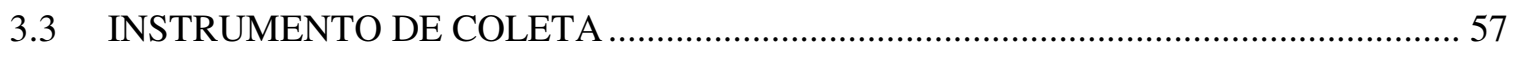

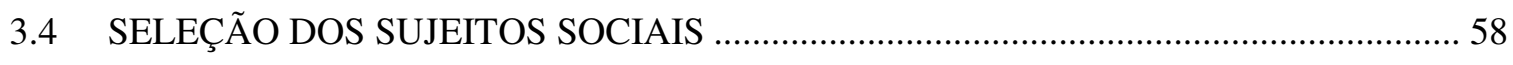

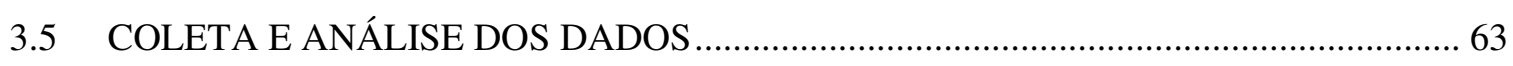

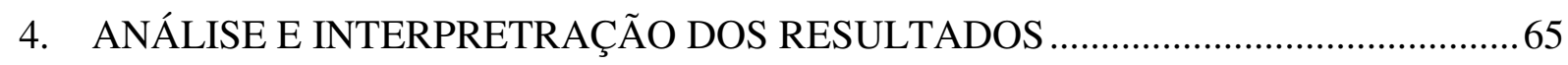

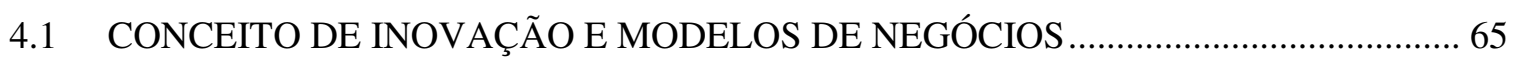

4.2 PROCESSO DE INOVAÇÃO E DESENVOLVIMENTO DE MODELO DE NEGÓCIO71

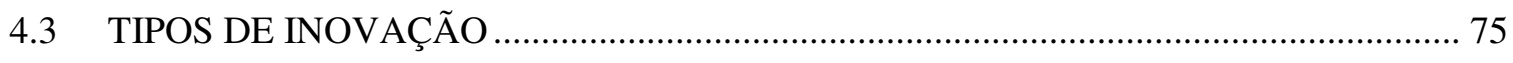

4.4 MOTIVAÇÕES, BARREIRAS E PAPEL DA LIDERANCA …….................................. 78

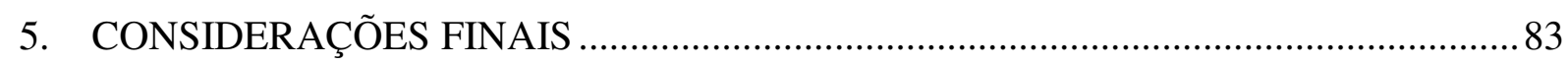

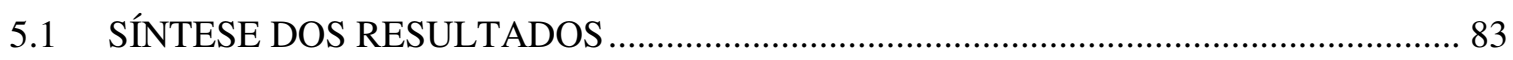

5.2 LIMITAÇÕES E RECOMENDAÇÕES PARA ESTUDOS FUTUROS ........................... 86

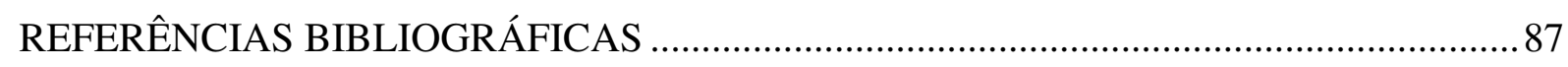

APÊNDICE: ROTEIRO DA PESQUISA QUALITATIVA ................................................ 91 



\section{INTRODUÇÃO}

As empresas tradicionais, que lideram o setor, tendem a reforçar seu domínio para conseguirem manter seus postos (CHRISTENSEN, 2003). No entanto, em comparação com as organizações estreantes, elas muitas vezes são conservadoras e ineficazes na exploração de inovações desbravadoras, ou seja, elas possuem maior dificuldade de inovar, pois continuam a fazer melhor o que as tornaram grande, buscando a eficiência e execução muito mais do que a inovação (CHRISTENSEN, 2000; MCKINSEY, 2015).

No entanto, inovar é crucial para a competitividade empresarial, conforme estudo realizado em 2008, pelo Banco Mundial e editado pela Confederação Nacional da Indústria (RODRIGUEZ; DAHLMAN; SALMI, 2008), que afirma que a competitividade se baseia muito mais na capacidade tecnológica e na inovação do que nos fatores básicos de produção.

Estudo mais recente realizado pela Accenture (2015) mostra que empresas que não conseguem alinhar suas aspirações de inovação com suas capacidades de inovação continuarão a ver concorrentes mais ágeis de dentro e fora de suas indústrias, bem como startups a incomodar seus negócios. Por outro lado, aquelas que desafiam o status quo e adotam uma inovação em modelo de negócio alcançará maiores retornos em seus investimentos em inovação e um novo nível de vantagem competitiva.

Em alguns setores produtivos, a importância da capacidade tecnológica e inovadora leva as empresas a repensarem a forma de condução dos seus negócios para se manterem vivas e competitivas. Di Serio e Vasconcellos (2008) afirmam que há uma disparidade da capacidade inovadora não só entre as empresas, mas também entre os seus setores internos. Conforme mostra a Figura 1, a inovação está presente em diversos segmentos, com destaque para os setores de engenharia elétrica, eletrônica e aeroespacial, farmacêutica, montadoras e fornecedores. 
Figura 1 - Dinâmica da inovação entre diferentes setores

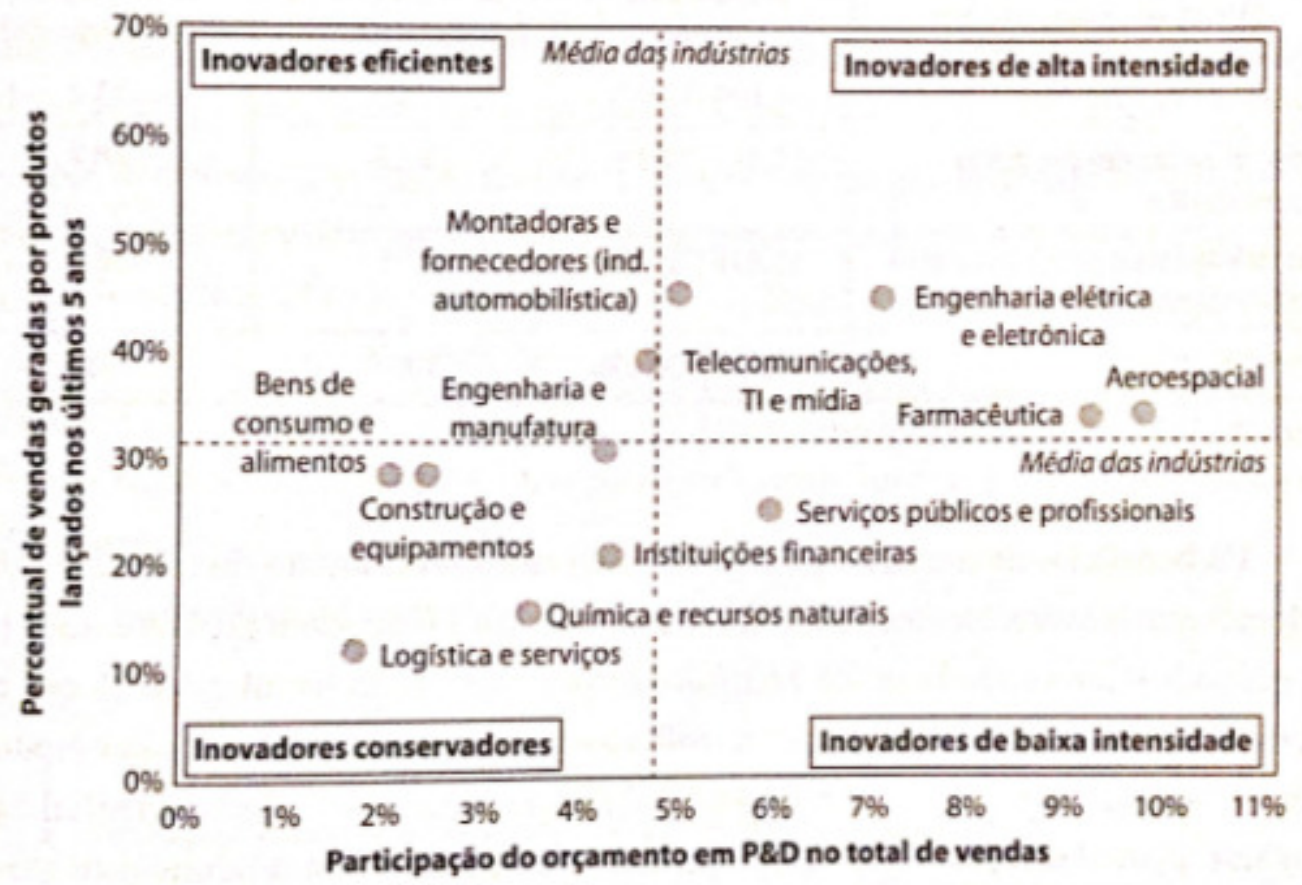

Fonte: LITTLE (2005, apud DI SERIO; VASCONCELLOS, 2008, p. 77).

Por outro lado, as empresas investem em desenvolvimento de tecnologias e ideias, mas pouco em inovação em modelos de negócios. O estudo conduzido pela Accenture (2015) ratifica esse fato, pois indica que apenas 30\% das empresas participantes investem esforços em inovar em modelos de negócio ao passo que 53\% investem em agregar valor a um produto já existente.

Dada à amplitude do tema, o presente estudo limita-se a abordar o modelo de negócios como desenvolvimento de novas áreas de negócio para empresas de grande porte, visando, então, a compreender a inovação como forma de rompimento de paradigmas, e a entender como grandes empresas inovam para se manterem competitivas, evitando, assim, o "Dilema de Inovação" (CHRISTENSEN, 2000).

\subsection{RELATO: DEFINIÇÃO DA SITUAÇÃO-PROBLEMA}

A forte internacionalização da economia brasileira levou ao aumento da competitividade no mercado e nas indústrias já consolidadas. Já a evolução tecnológica, bem como o aumento de incertezas, levou as organizações de diferentes setores a repensarem a forma como lidavam 
com seus negócios para continuar crescendo nesse novo cenário (FURR; DYER, 2014). Nesse contexto, a inovação é determinante para o sucesso de uma empresa no desenvolvimento tecnológico para a competitividade industrial e seu crescimento.

Uma saída para as empresas tradicionais superarem os novos desafios é se reinventarem, ou seja, inventar, desenvolver e aplicar ideias que conduzam a mudanças de modo a se manterem competitivas (SLYWOTZKY; MORRISON, 1998).

Para a mudança de modelo de negócios, as organizações têm que identificar líderes internos, a fim de gerenciar os resultados desses processos e entregar um novo e melhor modelo para a empresa. Ao mesmo tempo, a cultura da organização deve encontrar maneiras para conseguir adotar o novo modelo, mantendo a eficácia do atual modelo de negócios até que o novo esteja pronto para ser assumido completamente. Somente dessa forma os modelos de negócios podem ajudar as empresas a escapar da "armadilha" de seus modelos de negócios anteriores, renovando o crescimento e os lucros (CHESBROUGH, 2010).

Nesse cenário, em 2008, iniciei minha jornada em inovação. Depois de ter passado por algumas áreas de marketing e de novos negócios, passei a integrar o grupo de pessoas que teriam como desafio aproximar a competência de inovação das áreas de negócios de uma multinacional americana de bens de consumo duráveis, líder em seu segmento de atuação. Essa mudança estratégica estava alinhada com os desafios da empresa que, num ambiente cada vez mais desafiador em termos de resultados, deveria se diferenciar da acirrada concorrência, destacando-se entre as inúmeras opções de compra disponibilizadas ao consumidor pelo mercado.

Em quase quatro anos trabalhando nessa multinacional, dedicando-me exclusivamente à inovação, fui responsável pelo processo de geração de ideias para novos produtos, pela gestão do processo de desenvolvimento de inovação tecnológica e pela implementação do processo global de inovação. Juntamente com um time multifuncional de projetos, também fui responsável por lançar produtos inovadores e por conquistar diversos prêmios de inovação que reconheceram publicamente todos os esforços até então empreendidos.

No início de 2012, outra multinacional americana, cuja fonte de receita é quase que exclusivamente proveniente de um único produto voltado para mercados e segmentos B2B (Business to Business) e B2C (Business to Consumer), decidiu investir esforços na busca de oportunidades que agregassem serviços ou novos produtos em busca de novas fontes de receitas. E, assim, no final de 2012, decidi que era hora de inovar em outra empresa e passei a integrar o time de inovação da América Latina, que tinha como desafio inovar fora do seu core business. 
Naquele momento, a empresa visava a novas fontes de receita e passou a buscar iniciativas de inovação para melhorar a experiência com o produto, a fomentar o empreendedorismo corporativo com foco em inovações incrementais e a desenvolver novos negócios. No entanto, para que essas ações trouxessem resultados efetivos para a organização, algumas mudanças deveriam ser realizadas, como a estruturação de uma área responsável regionalmente pelo desafio de inovar fora do core business, a elaboração de processos de gestão de inovação, e o repensar a cultura da empresa.

Com base na minha experiência profissional e vivência nessas duas grandes empresas multinacionais tive a oportunidade de presenciar a forma com ambas enfrentaram os desafios oriundos da mudança de cenário competitivo e do aumento de incertezas de negócios. A postura voltada para a prática efetiva da inovação, que cada empresa tomou para si, foi e tem sido fundamental para que continuem crescendo, cada qual em seus respectivos segmentos. Essa vivência acabou me despertando certos questionamentos, levando-me a propor a entender como grandes empresas inovam, buscando implementar modelos de negócios para se manterem competitivas.

\subsection{PROBLEMA DE PESQUISA, OBJETIVOS E ESTRUTURAÇÃO DO TRABALHO}

Com base nas considerações supramencionadas, elegeu-se como problema de pesquisa do presente estudo investigar Como a inovação por meio do desenvolvimento de modelo de negócios contribui para a competitividade de grandes empresas?

Para tanto, definiu-se como objetivo principal compreender a maneira como especialistas que trabalham em grandes empresas inovam e desenvolvem modelos de negócios para atender às demandas de mercado, visando à competitividade e à sobrevivência do negócio.

Não obstante, o presente estudo tem como objetivos específicos:

- Apresentar o entendimento de inovação e modelos de negócios a partir da percepção de especialistas que atuam em grandes organizações;

- Descrever como os especialistas conduzem a gestão de inovação e como esta se relaciona com o desenvolvimento de modelos de negócios nas grandes organizações;

- Identificar os tipos de inovação nos quais os especialistas que trabalham em grandes organizações estão envolvidos; 
- Identificar as motivações e barreiras enfrentadas na jornada de implantação da inovação voltada para o desenvolvimento de modelos de negócios.

Assim, o presente estudo apresenta-se estruturado em 5 (cinco) capítulos, os quais abordam os principais temas inerentes aos objetivos de cada um deles, como se pode visualizar na Figura 2.

Figura 2 - Estrutura do presente estudo

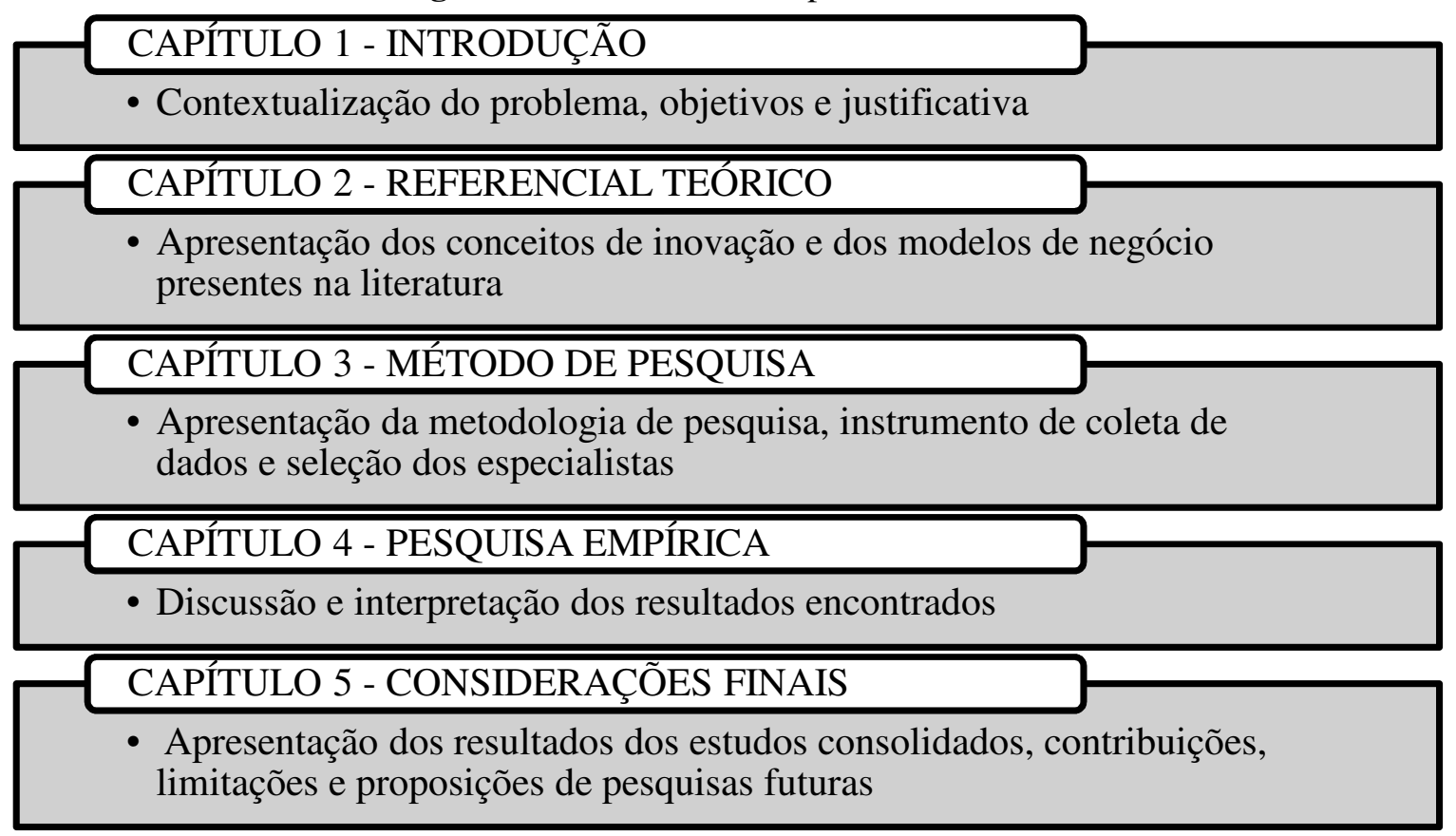

Fonte: Elaborada pela autora (2017). 


\section{REFERENCIAL TEÓRICO}

Com o intuito de compreender, à luz da teoria, as decisões tomadas pelos que atuam em grandes organizações para inovar em busca da competitividade, o presente estudo está ancorado em dois grandes temas: Inovação e Modelos de Negócios, conforme demonstra a Figura 3, como forma de encontrar o equilíbrio entre esses temas para a competitividade das empresas.

Figura 3 - Estrutura do referencial teórico

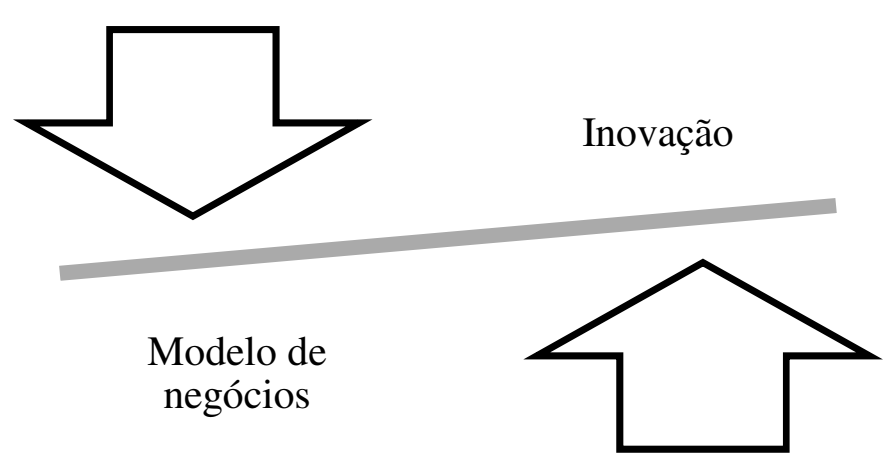

Fonte: Elaborada pela autora (2017).

Primeiramente cabe compreender o papel da inovação nas estratégias das empresas, estabelecendo um direcionamento para o desenvolvimento de modelos de negócios que possam ser um caminho para a vantagem competitiva se o modelo for suficientemente diferenciado e difícil de replicar pelos competidores (TEECE, 2010). Não obstante, a temática da inovação, seus processos e gestão ajudaram a compreender o que e como as empresas desenvolvem suas inovações, visando à competitividade.

\subsection{INOVAÇÃO}

\subsubsection{Definição de Inovação}

Como o mercado tornou-se muito competitivo, ter um diferencial no produto e/ou no serviço tornou-se imprescindível. Assim, a inovação pode ser considerada como o elemento chave para prover o crescimento e a diferenciação nas empresas. Para Michael Porter (1999), 
as empresas atingem a vantagem competitiva por meio das iniciativas de inovação. Cabe esclarecer que abordam a inovação em seu sentido mais amplo, abrangendo novas tecnologias e novas maneiras de se fazer as coisas.

Para Drucker (2011), além de ser um instrumento específico dos empreendedores, o meio pelo qual eles exploram a mudança pode ser considerado uma oportunidade para um negócio ou um serviço diferente, a inovação é um esforço para criar uma mudança proposital focada em uma empresa de potencial econômico ou social, ou seja, é a exploração com sucesso de novas ideias (DRUCKER, 2002).

Por outro lado, o Manual de Olso tem uma abordagem mais abrangente ao definir inovação como "a implementação de um produto (bem ou serviço) novo ou significativamente melhorado, ou um processo, ou um novo método de marketing, ou um novo método organizacional nas práticas de negócios, na organização do local de trabalho ou nas relações externas" (OCDE, 1997, p.55).

Schumpeter (1997) e Drucker (2011) relacionam inovação com a criação de novos mercados e com a ação de empreender. O conceito de inovação, concebido por Schumpeter (1997), considera que o desenvolvimento econômico é também definido pela realização de novas combinações e estabelecimento de uma nova organização.

As inovações no sistema econômico não aparecem, via de regra, de tal maneira que primeiramente as novas necessidades surgem espontaneamente nos consumidores e então o aparato produtivo se modifica sob sua pressão. Entretanto, é o produtor, via de regra, que inicia a mudança econômica, e os consumidores são educados por ele, se necessário; são por assim dizer, ensinados a querer coisas novas, ou coisas que diferem em um aspecto ou outro daquelas que tinham o hábito de usar (SCHUMPETER, 1997, p. 76).

A maioria das inovações, especialmente as de maior sucesso, resultam de uma consciente busca intencional de oportunidades de inovação, encontradas apenas em algumas situações. Tais situações existem dentro da própria empresa, em fontes internas de inovação, como ocorrências inesperadas, incongruências, necessidades do processo e da indústria e de mudanças do mercado; ou podem, ainda, originar de uma oportunidade externa ao seu contexto social e ambiente intelectual, como mudanças demográficas, mudanças na percepção e novos conhecimentos (DRUCKER, 2002). Esse cenário, denominado por Chesbrough (2003b) como "paradigma da inovação fechada", levou a importantes realizações e a muitos sucessos comerciais. A Figura 4 ilustra como o desenvolvimento de novas ideias emerge em programas de inovação fechada. 
Figura 4 - Modelo de programas de inovação fechada

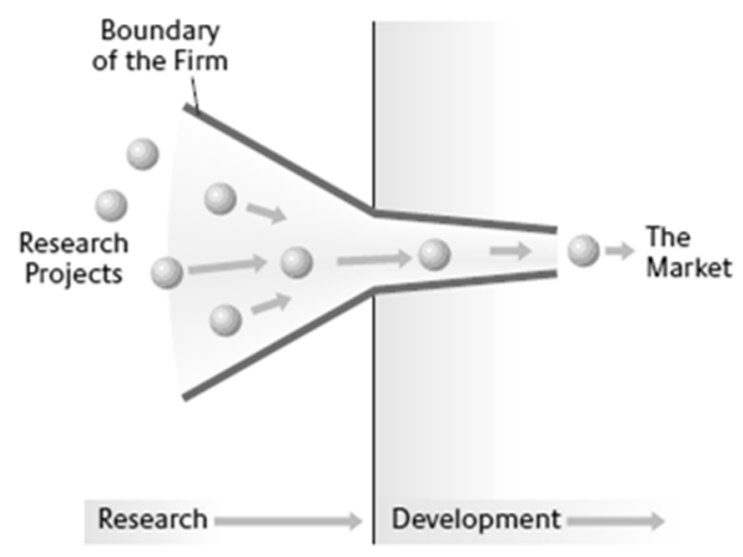

Fonte: CHESBROUGH, 2003b, p. 36.

No paradigma da inovação fechada, a empresa cria, desenvolve e comercializa suas próprias ideias que fluem da empresa para o mercado. Elas são selecionadas e filtradas durante o processo de investigação. As selecionadas são transferidas para o desenvolvimento e a seguir são levadas para o mercado. Este conceito assume que, implicitamente, todas essas atividades são realizadas internamente na empresa. Desde que a empresa mantenha um fluxo de novas ideias em seu funil de inovação, muitas delas se transformam em novos produtos e a empresa captura o valor a partir dessas criações. No entanto, esse paradigma está cada vez mais em desacordo com a perspectiva do conhecimento no início do século XXI, quando o conhecimento está difundido, além das áreas internas de P\&D, passando por fornecedores, clientes, parceiros, universidades, startups, consultores e outros terceiros externos às organizações (CHESBROUGH, 2003b).

No modelo de inovação fechada, as empresas desenvolvem novos produtos para os consumidores. Nesse processo, os consumidores são receptores passivos - apenas compram e consomem o que as empresas lançam no mercado. No entanto, um estudo liderado por Von Hippel, Ogawa e De Jong (2011) demonstrou que esse paradigma tradicional de inovação é falho, uma vez que os próprios consumidores podem ser importantes fontes de inovações de produtos.

Nesse cenário, a inovação aberta, ou open innovation, significa que ideias valiosas podem vir de dentro ou de fora da empresa e, da mesma forma, podem ir para o mercado de dentro ou de fora da empresa. Essa abordagem, disseminada por Chesbrough (2003b), coloca ideias e caminhos externos ao mercado no mesmo nível de importância que as ideias e caminhos para o mercado, como ocorria com o modelo de inovação fechada. A Figura 5 ilustra como as ideias fluem entre diferentes empresas no modelo de programa de inovação aberta. 
Figura 5 - Modelo de programa de inovação aberta

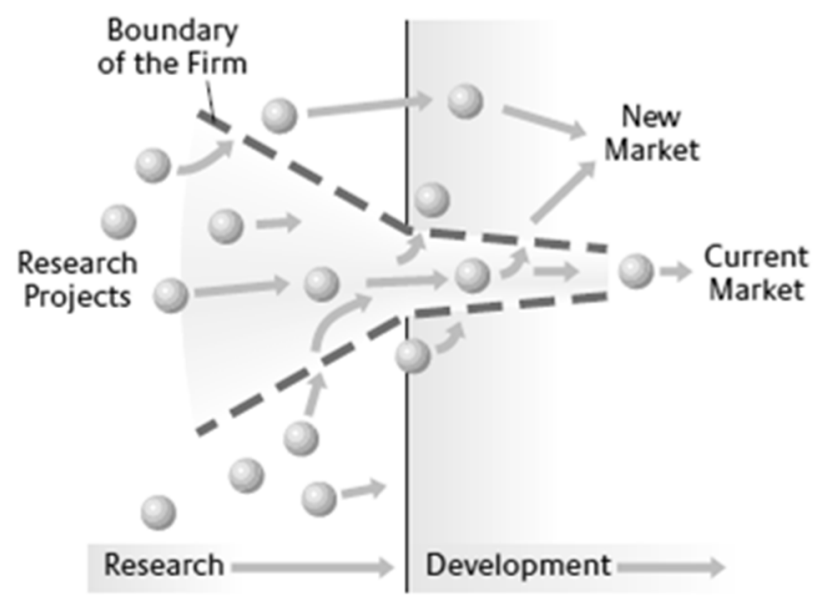

Fonte: CHESBROUGH, 2003b, p. 37.

Nesse ambiente de inovação, as ideias nascem não apenas dentro de cada empresa, mas também fora delas. Essas ideias estão disponíveis para serem usadas e, muitas vezes, as pessoas que as criaram promovem seu uso. As barreiras entre a empresa e o meio no qual ela está inserida estão propensas à troca de ideias, permitindo que estas circulem mais facilmente (CHESBROUGH, 2003b).

No modelo de inovação aberta, as ideias podem ser geradas em universidades, por fornecedores ou até mesmo pelos usuários, denominados por Von Hippel (2005) como “lead users". Eles desenvolvem e modificam produtos para si próprios e são propensos a adotar soluções desenvolvidas por outros lead users. Esse contexto oferece a base dos sistemas de inovação centrados no usuário que podem perfeitamente superar um fabricante. Neste último caso, as empresas precisam repensar em como organizar o seu processo de desenvolvimento de produto, de maneira a acatar e construir inovações, com base em protótipos desenvolvidos pelos próprios usuários (VON HIPPEL; OGAWA; DE JONG, 2011).

Nesse sentido, o processo de explorar novas oportunidades em empresas já estabelecidas está repleto dos mesmos riscos que aqueles enfrentados por startups e empresas menores. Isso acontece, em parte, porque os resultados da inovação, que é uma atividade empresarial do cerne, são difíceis de se prever (PHAN et al., 2009).

No entanto, apesar dos riscos inerentes à inovação, explorar novas oportunidades pode levar à satisfação do cliente e à fidelidade dos mesmos à marca; ajudar a manter os funcionários satisfeitos; aumentar a satisfação e preferências dos parceiros; além de aumentar o market share das empresas. Todos esses benefícios, por sua vez, traduzem-se em considerável desempenho 
financeiro, ou seja, melhores rendimentos aos investidores e excelente saúde financeira. Assim, as empresas que oferecem o crescimento dos lucros com base em um fluxo contínuo de novos produtos e serviços e novas formas de fazer negócios capturam nesse processo o valor da inovação (JONASH; SOMMERLATTE, 2001).

Compreendida a importância estratégica, característica da inovação, em busca da competitividade empresarial, faz-se necessário compreender a sua execução por meio de processos para que o desdobramento da estratégia se converta em ações e resultados para a empresa.

\subsubsection{Processos de Inovação}

Ainda que o processo de inovação possa ocorrer ao acaso, para agregar valor de forma consistente é preciso ter foco estratégico na inovação. Uma organização inovadora não pode se basear em uma estratégia deliberada devido ao ambiente complexo e imprevisível no qual está inserida, ao contrário, suas ações devem ser decididas individualmente, conforme as necessidades identificadas para cada momento (MINTZBERG et al., 2006).

Sendo a gestão da inovação um processo complexo composto por uma série de atividades interdisciplinares que demandam disciplina e, principalmente, engajamento das pessoas envolvidas na execução das atividades para que o resultado seja exitoso (COOPER, KLEINSCHMIDT, 1986) existem diferentes modelos de processos para o desenvolvimento da inovação.

A visão das atividades de desenvolvimento de novos produtos de forma sequencial, por etapas, e dependente de entregas anteriores, proposta e revista por Cooper (1994), leva em conta a importância da participação de diversas áreas da organização e a necessidade de uma visão holística desde a ideia até ao lançamento, com forte orientação para o mercado consumidor e para a adaptabilidade do processo, conforme características do projeto desenvolvido. 
Figura 6 - Comparação da segunda geração do processo de Stage-Gates com o que pode parecer o processo de terceira geração

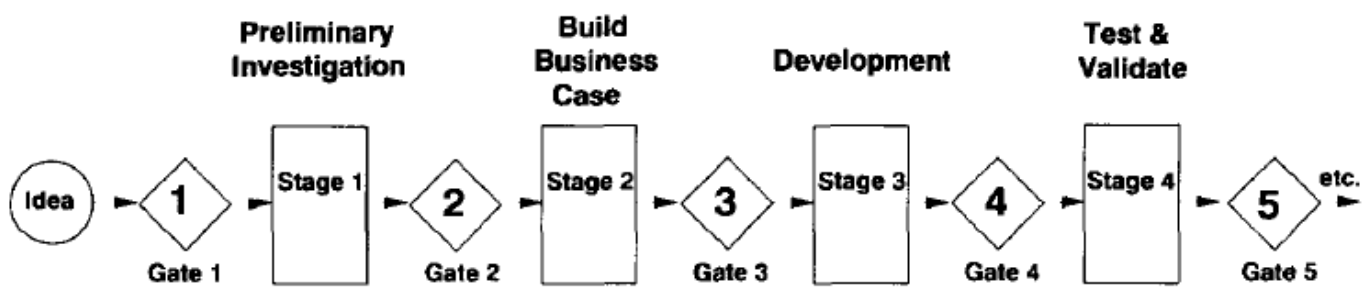

Today's stage-gate process.

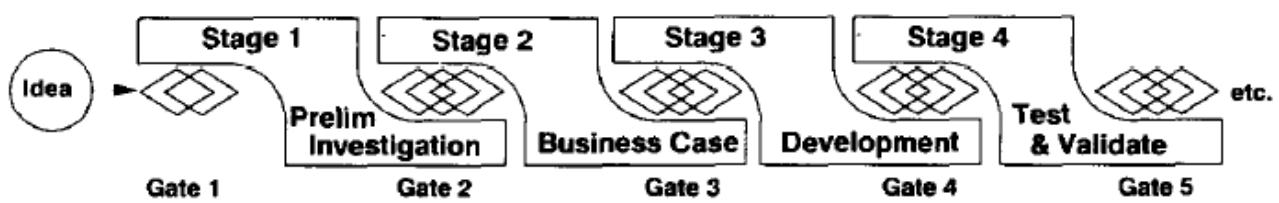

Fonte: COOPER,1994, p. 5.

A segunda geração do processo de Stage-Gates, conforme Figura 6, é mais rígida, pois há necessidade de conclusão da etapa anterior para então dar início à etapa seguinte. Dependendo do mercado no qual a inovação está inserida, é mais adequada uma decisão condicional, como proposta na terceira geração do processo de Stage-Gates, visando à maior fluidez, reduzindo a burocracia, sendo mais flexível, porém sem perder o foco.

Ao considerar que a gestão tecnológica não corresponde somente a inovar com sucesso uma vez ou duas, mas sim a inovar e a melhorar frequentemente, o Temaguide (contração das palavras technology, management e guide, resultado de uma pesquisa desenvolvida por um grupo de organizações europeias) recomenda um modelo que facilite o enfoque na inovatividade. Este modelo é baseado em cinco elementos: monitoramento, focalização, alocação de recursos, implementação e aprendizado, conforme ilustra a Figura 7. 
Figura 7 - Modelo Temaguide de Inovação

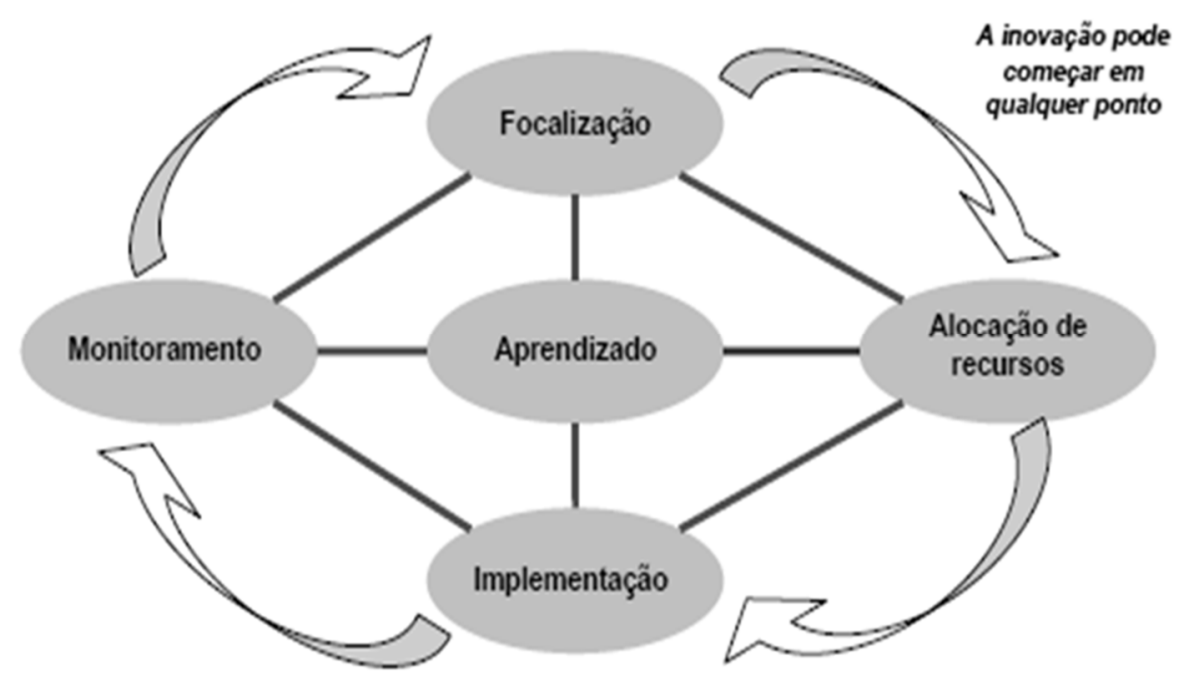

Fonte: Adaptado de COTEC (1998).

O monitoramento consiste em observar o ambiente interno e externo, a fim de perceber as mudanças que estão ocorrendo na legislação e no comportamento dos consumidores e, por consequência, quais oportunidades estão disponíveis. A focalização, por sua vez, refere-se ao direcionamento dos esforços em uma estratégia para a inovação e o melhoramento dos negócios, buscando encontrar alternativas que poderão oferecer maior vantagem competitiva. A alocação de recursos refere-se a encontrar o conhecimento necessário para desenvolver a alternativa selecionada. A implementação consiste em desenvolver a alternativa escolhida e em efetivá-la. E, por fim, o aprendizado busca a internalização dos conhecimentos gerados no processo de inovação, sejam de sucessos ou de insucessos, com o objetivo de melhorar seu gerenciamento. É importante salientar que o processo é cíclico, portanto a inovação pode começar em qualquer ponto do modelo.

Por outro lado, a gestão da inovação definida por Birkinshaw e Hamel (2008) como a geração e implementação da prática de gestão, processo, estrutura ou técnicas, destina-se a promover os objetivos organizacionais e envolve a introdução de alguma novidade em uma organização já estabelecida, favorecendo uma mudança organizacional. A Figura 8, por exemplo, ilustra a estrutura para a gestão da inovação, proposta por Birkinshaw e Hamel (2008), por meio de ações de agentes internos e externos representados na vertical; as fases do processo de inovação representados na horizontal pela motivação, invenção, implementação e teorização/rotulagem; os tipos de inovação que se apresentam numerados; e as atividades 
centrais representadas pelas setas em ambos os sentidos. Ou seja, diversas variáveis devem ser consideradas também nesse modelo.

Figura 8 - Estrutura da gestão do processo de inovação

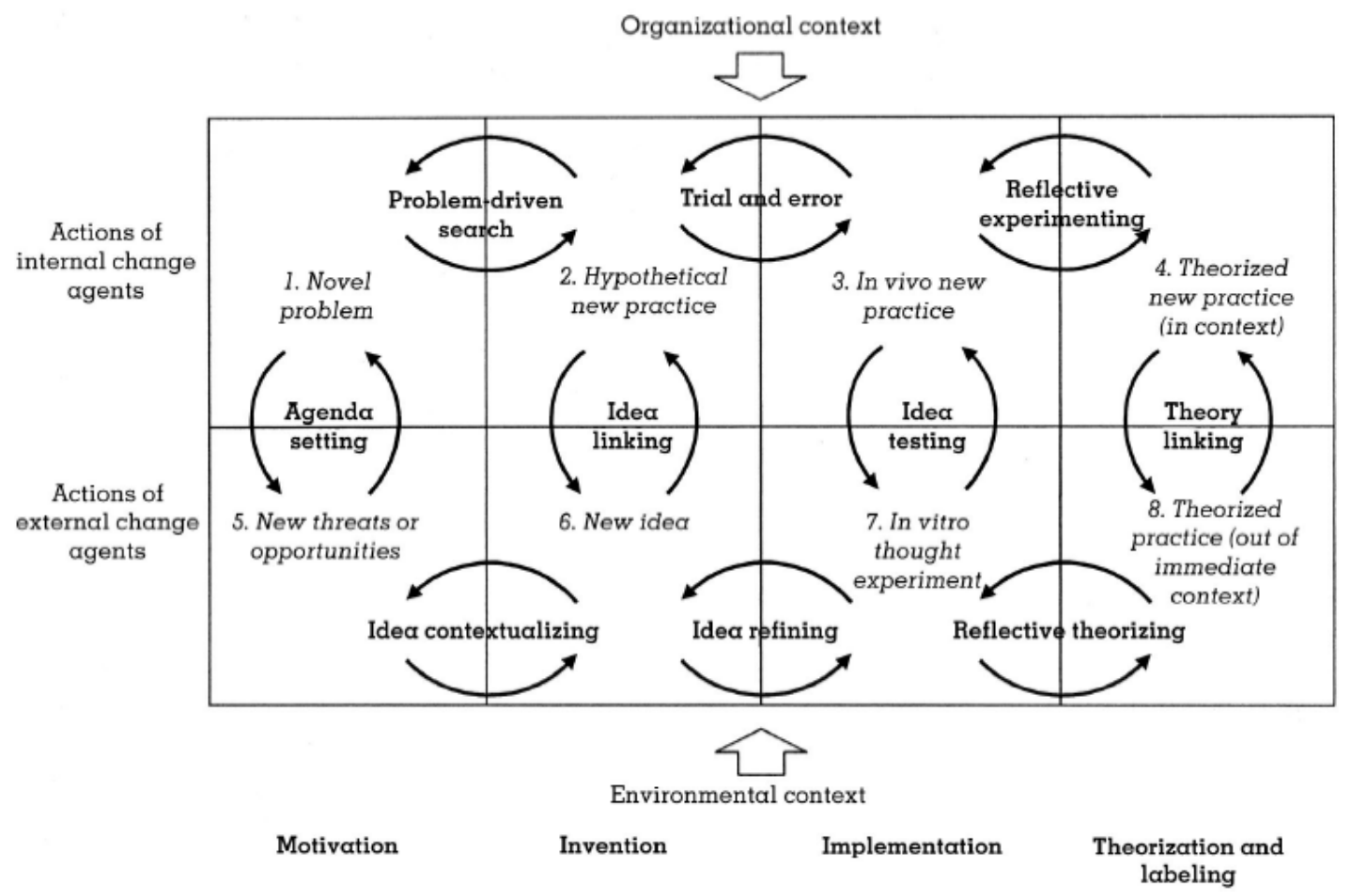

Fonte: BIRKINSHAW; HAMEL, 2008, p. 832.

Tidd, Bessant e Pavitt (2008), no entanto, propõem um processo mais simples para a gestão de inovação, passando pelas etapas de busca de oportunidades, seleção de uma oportunidade e sua implementação por meio da execução, conforme representado na Figura 9.

Figura 9 - Representação do processo de inovação simplificado

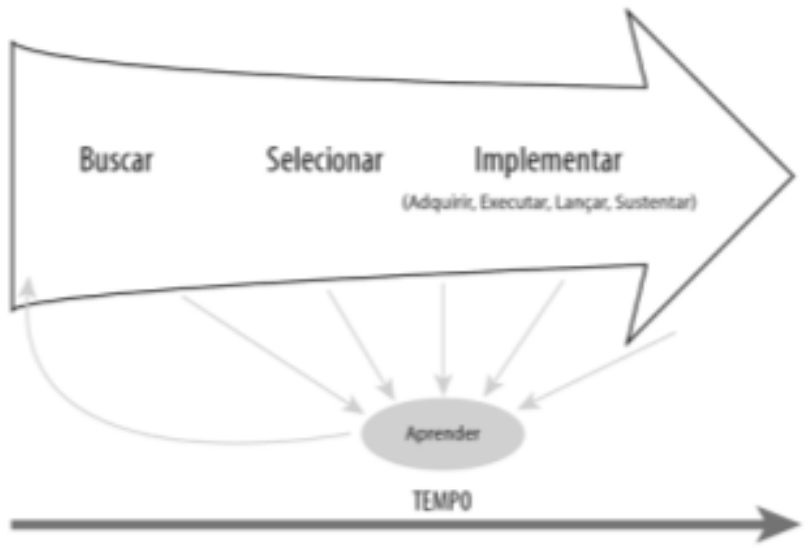

Fonte: TIDD; BESSANT; PAVITT, 2008, p. 88. 
Veryzer (1998) propõe um processo de inovação de produto descontinuado específico para inovações radicais - Figura 10 -, no qual o desenvolvimento de um protótipo tem a função de explorar e formular o aspecto tecnológico do produto e assim desenvolver uma aplicação para a nova tecnologia por meio de testes com lead users.

Figura 10 - Processo de inovação de produto descontinuado

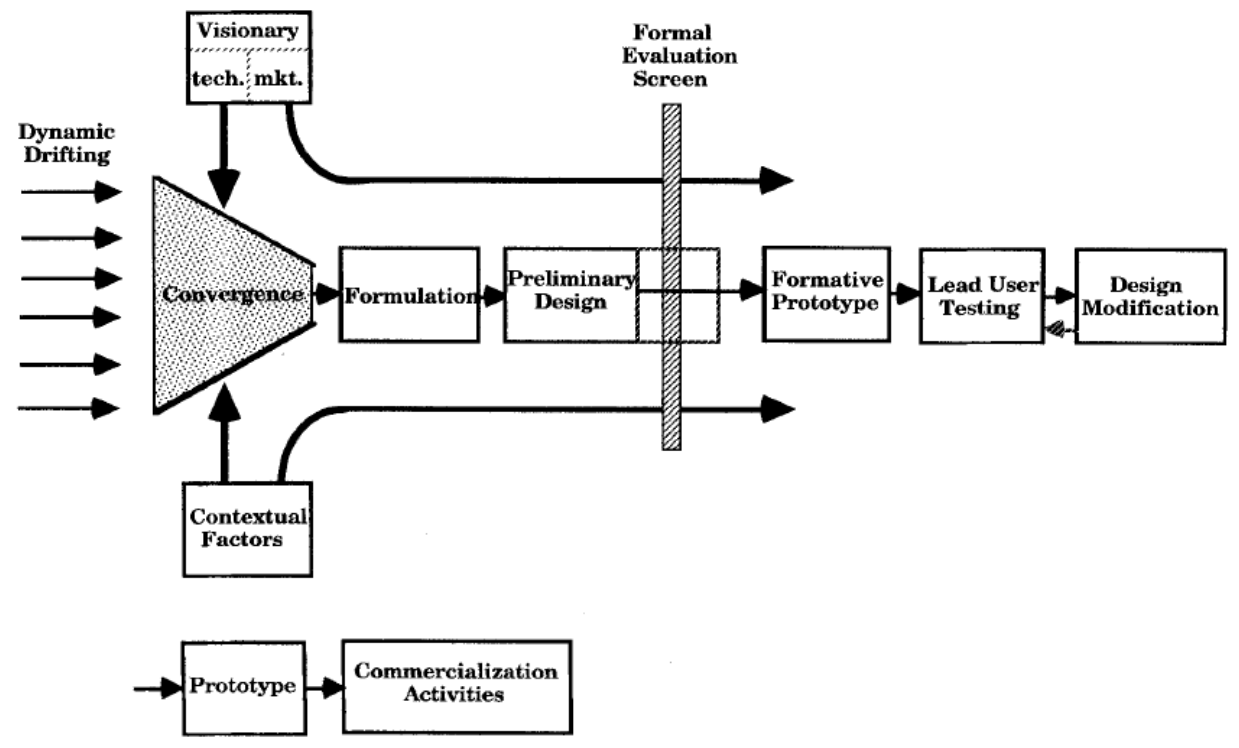

Fonte: VERYZER, 1998, p. 317.

Apesar de não ser um componente necessário segundo a definição, Birkinshaw e Hamel (2008) reforçam a perspectiva sobre a gestão de inovação, chamando a atenção conscientemente para os indivíduos que dirigem o processo. Da mesma forma, segundo Christensen (2003), até que se desenvolva um processo competente para o gerenciamento eficaz da inovação, um dos recursos mais cruciais de que necessitam os negócios para alcançarem o sucesso continua sendo a supervisão pessoal pelos executivos seniores. Não obstante, para que os processos de inovação ocorram de forma plena, dependem fortemente da ação gerencial, por serem carregados de pontos de tomada de decisão e de distribuição de responsabilidades (STEFANOVITZ, 2011).

Ainda que a gestão de inovação leve em consideração processos estruturados, mais complexos ou mais simplistas, Kuemmerle (2006) sugere que a habilidade das grandes empresas em inovar parece diminuir conforme seu crescimento. Isso acontece devido às barreiras comportamentais internas ou as específicas de contexto. Assim, a organização precisa ver a mudança como oportunidade e não como uma ameaça (DRUCKER, 2011). 


\subsubsection{Tipos de Inovação}

O tipo de inovação que a empresa opta por desenvolver impacta nos resultados competitivos que irá alcançar, bem como no modelo de negócios estabelecido. Isso significa que uma mesma ideia pode ter resultados econômicos diferentes devido à abordagem do modelo de negócios (CHESBROUGH, 2003a).

A terceira edição do Manual de Oslo (1997) diferencia quatro tipos principais de inovação: de produto, de processo, de marketing e organizacional. As duas primeiras, de produto e de processo, estão relacionadas estreitamente com os conceitos de inovação tecnológica de produto e inovação tecnológica de processo, respectivamente. As inovações de marketing são voltadas para melhor atender às necessidades dos consumidores, abrindo novos mercados, ou reposicionando o produto de uma empresa no mercado, por meio de mudanças no seu design, alterando as características funcionais ou de uso. A inovação organizacional, por sua vez, modifica as práticas de negócios da empresa, a organização do seu local de trabalho, ou a forma como essa se relaciona externamente.

Segundo Davila, Epstein e Shelton (2005), as inovações segundo sua intensidade podem ser divididas em três tipos: incremental, semi-radical e radical. A inovação incremental busca extrair o máximo valor de produtos e serviços existentes, sem a necessidade de fazer mudanças significativas ou grandes investimentos. Fornece, portanto, uma proteção em relação à corrosão causada pela concorrência. Como essa inovação trabalha com tempo e riscos menores, as organizações tendem a escolher projetos incrementais em detrimento de projetos de inovação radical, mesmo que estes possam proporcionar maiores ganhos.

A inovação semi-radical, por sua vez, envolve uma mudança substancial no modelo de negócios ou na tecnologia de uma organização. Por fim, a inovação radical envolve uma mudança significativa que afeta simultaneamente tanto o modelo de negócios, quanto a tecnologia de uma empresa. A Figura 11 apresenta os tipos de matriz de inovação propostos por Davila, Epstein e Shelton (2005). 
Figura 11 -Tipos de Matriz de Inovação

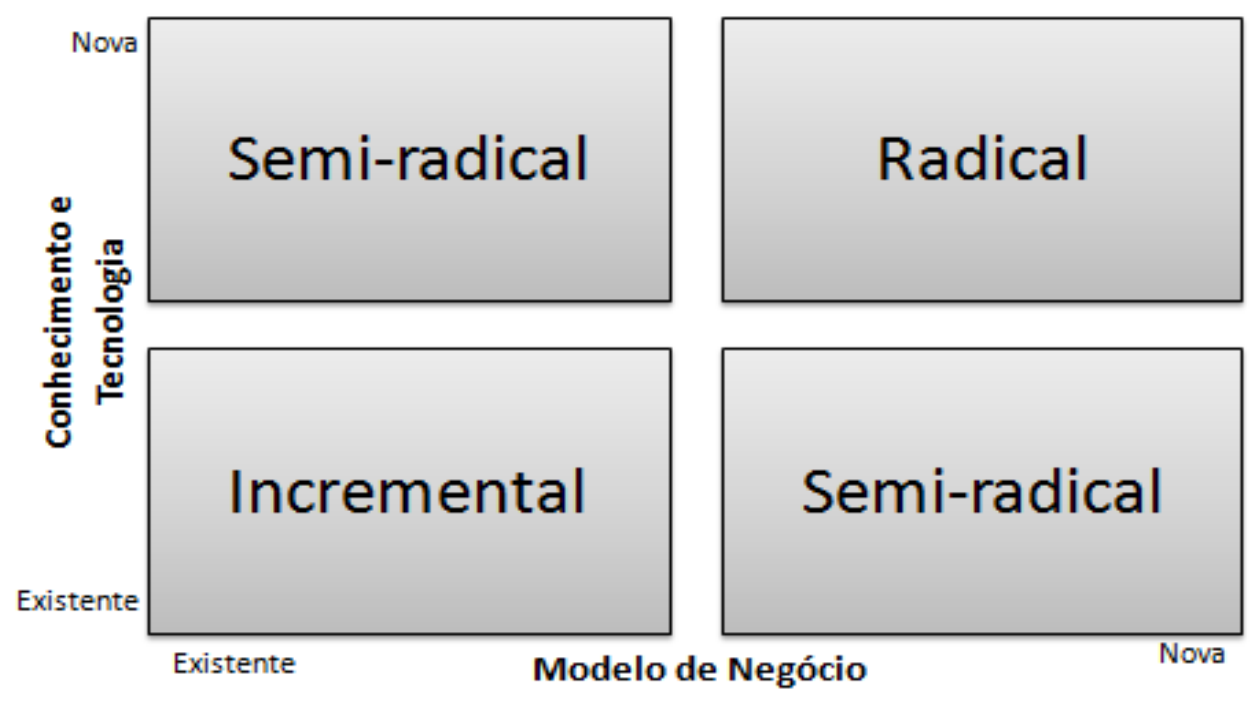

Fonte: Adaptado de Davila, Epstein e Shelton (2005).

Para Christensen (2000), no entanto, há três tipos de inovação que criam oportunidades de crescimento para as empresas: inovação de sustentação, de ruptura e de modelo de negócio. Os dois primeiros estão relacionados com a venda de produtos e de desenvolvimento tecnológico, a saber.

- A inovação de sustentação ajuda as empresas a manterem o negócio atual, mas não traz muitas mudanças ao vender produtos melhores para seus consumidores.

- A inovação de ruptura transforma o mercado antes dominado por empresas que ofereciam produtos caros, passando a oferecer produtos mais simples e acessíveis.

- A inovação de modelo de negócios permite conquistar novos consumidores com maior eficiência e a um custo inferior ao praticado até então. Esse tema será abordado posteriormente (a partir do item 2.2 desta dissertação).

A Figura 12 permite constatar que, com o decorrer do tempo, o avanço tecnológico passa a ser superior à demanda de mercado, fazendo com que as empresas invistam em novas tecnologias para atender a uma demanda ainda inexistente. A inovação de ruptura apresenta tecnologias mais acessíveis para um novo mercado. 
Figura 12 - Impacto da mudança tecnológica de sustentação e de ruptura

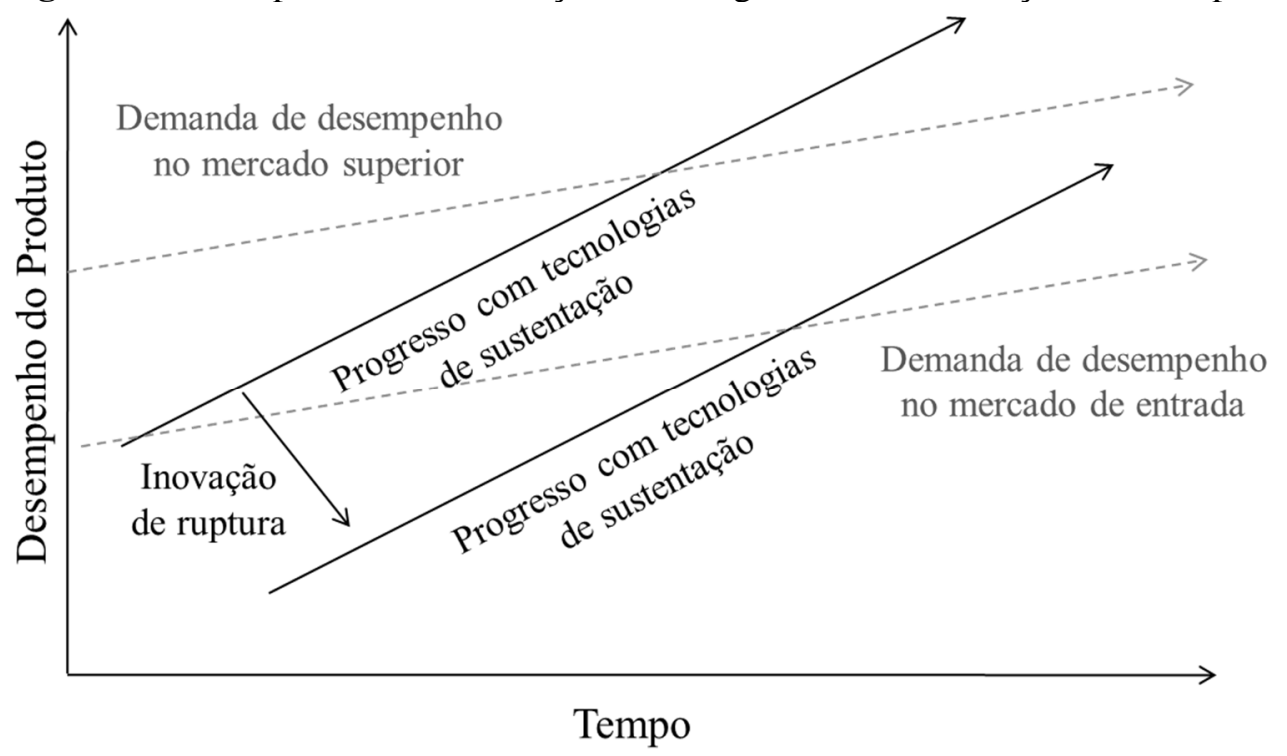

Fonte: Adaptado de Christensen (2000).

Algumas inovações são disruptivas ou de ruptura, destroem e tornam obsoleta a competência estabelecida; outros as refinam e as melhoram. Não obstante, diferentes tipos de inovação requerem diferentes tipos de ambientes organizacionais e de habilidades gerenciais (ABERNATHY; CLARK,1985). Dessa forma, o modelo de inovação guia o tipo de inovação a ser desenvolvida, bem como o tipo de inovação determina modelos organizacionais e seus processos.

Abernathy e Clark (1985) classificam a inovação de acordo com seu nível tecnológico ou de mercado, e definem quatro tipos:

- Arquitetônica: usa novos conceitos em tecnologia para forjar novas ligações de mercado.

- Nicho: abre novas oportunidades de mercado por meio da utilização de tecnologia existente.

- Regular: muitas vezes quase invisível, tem um efeito cumulativo no custo e no desempenho do produto.

- Revolucionária: inovação que perturba e estabelece técnica e competência de produção obsoleta, ainda não aplicada a mercados existentes e atuais clientes.

Apesar de a inovação radical ter um papel importante na construção de vantagem competitiva (VERYZER, 1998), as empresas, normalmente, usam estratégias radicais apenas 
quando mudanças no seu ambiente tornam o negócio atual obsoleto ou quando voluntariamente decidem desenvolver um novo modelo de negócios. Além de ser arriscada, poucas empresas e gestores possuem experiência nesse tipo de mudança (YIP, 2004).

Em alguns casos, a inovação pode ser bem-sucedida ao empregar um modelo de negócio já estabelecido na empresa, em outros, esse modelo de negócio pode não ser adequado às circunstâncias da tecnologia ou mesmo da oportunidade do mercado (CHESBROUGH; ROSENBLOOM, 2002, p. 530).

Os modelos de negócios podem reestruturar as indústrias e gerar um crescimento extraordinário. No entanto, muitas empresas encontram dificuldades em inovar em modelos de negócios pelo fato de que os gestores não compreendem suficientemente o modelo existente para saber quando precisam mudá-lo ou então porque não saibam como mudar (JOHNSON; CHRISTENSEN; KAGERMANN, 2008). Nesse sentido, vale entender o conceito de aplicação de modelo de negócios para que as empresas tenham sucesso na implantação de suas estratégias de inovação, o que será abordado posteriormente.

Antes de abordar o segundo tema do estudo - Modelos de Negócios, sua definição e seu desenvolvimento - o Quadro 1 resume as ideais principais estabelecidas pelos teóricos sobre inovação e que direcionaram a presente pesquisa de campo, a ser discutida no Capítulo 3 Procedimentos Metodológicos. 
Quadro 1 - Resumo das ideias principais sobre inovação

\begin{tabular}{|l|l|l|}
\hline Inovação & \multicolumn{1}{|c|}{ Autores } & \multicolumn{1}{c|}{ Ideia principal } \\
\hline \multirow{5}{*}{ Conceito } & Drucker (2002) & Exploração com sucesso de novas ideias. \\
\cline { 2 - 3 } & Drucker (2011) & Criação de um negócio ou serviço. \\
\cline { 2 - 3 } & Schumpeter (1997) & Criação de novos mercados; empreendedorismo. \\
\cline { 2 - 3 } & Chesbrough (2003b) & Inovação aberta e fechada. \\
\cline { 2 - 3 } & OCDE (1997) & Produto, processo ou método novo ou melhorado. \\
\cline { 2 - 3 } Tipos & Von Hippel (2005) & Soluções desenvolvidas por lead users. \\
\hline \multirow{5}{*}{$\begin{array}{l}\text { Davila, Epstein e Shelton } \\
(2005)\end{array}$} & Incremental, semi-radical e radical. \\
\cline { 2 - 3 } & OCDE (1997) & Produto, processo, marketing e organizacional. \\
\cline { 2 - 3 } & Christensen (2000) & De sustentação, de ruptura e de modelo de negócios. \\
\cline { 2 - 3 } & Abernathy e Clark (1985) & Arquitetônica, nicho, regular e revolucionária. \\
\hline \multirow{5}{*}{ Processos } & Cooper (1994) & Stage-Gates. \\
\cline { 2 - 3 } & COTEC (1998) & Modelo Temaguide. \\
\cline { 2 - 3 } & Birkinshaw e Hamel (2008) & $\begin{array}{l}\text { Agentes internos e externos, contexto organizacional } \\
\text { e contexto ambiental. }\end{array}$ \\
\cline { 2 - 3 } & Tidd; Bessant; Pavitt (2008) & Busca por oportunidades, escolha e desenvolvimento. \\
\cline { 2 - 3 } & Veryzer (1998) & Protótipos e lead users. \\
\hline
\end{tabular}

Fonte: Quadro elaborado pela autora, com base em diversos autores (2017).

\subsection{MODELOS DE NEGÓCIOS}

\subsubsection{Definição de Modelos de Negócios}

O conceito de modelo de negócios tornou-se popular devido à dificuldade que os gestores têm em tomar decisões em um ambiente de negócios moldado por tecnologias e pela globalização e caracterizado por crescentes complexidades e incertezas (OSTERWALDER, 2004).

Popularmente, o termo 'modelo de negócios' é entendido como estratégia da empresa, sendo específico para cada organização. No entanto, é importante deixar clara a sua definição, que é sempre ancorada em seu próprio ambiente competitivo particular. Assim, um modelo de negócios pode ser concebido como uma abstração da estratégia de uma empresa (SEDDON; LEWIS, 2003). 
Toda organização tem um modelo de negócios próprio, pois cada qual faz determinadas escolhas que podem levar a determinadas consequências. Além disso, um mesmo modelo de negócios pode ser aplicado a mais de uma empresa. Da mesma forma, a estratégia de uma empresa pode ser representada por qualquer número de modelos de negócios (SEDDON; LEWIS, 2003). No entanto, não significa que cada modelo de negócios seja satisfatório, ou mesmo viável a longo prazo (CASADESUS-MASANELL; RICART, 2010). A Figura 13 demonstra que pode haver dois tipos diferentes de modelo de negócios que representam a estratégia da empresa, embora não haja um número limitado de diferentes modelos que se possa constituir com base na estratégia da organização.

Figura 13 - Relação entre modelo de negócios e estratégia de uma empresa

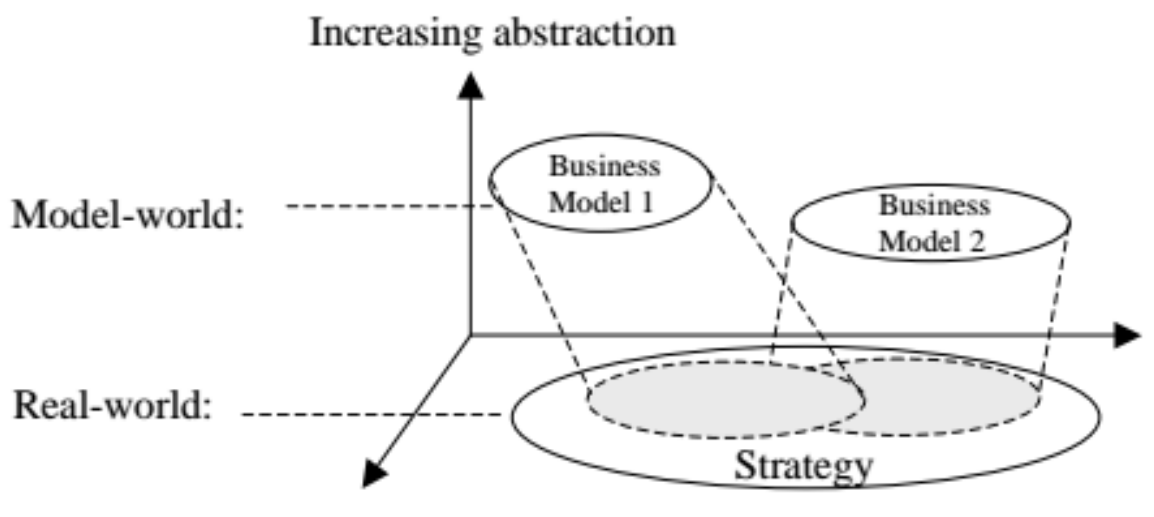

Fonte: SEDDON; LEWIS, 2003, p.238.

Para Casadesus-Masanell e Ricart (2010), o modelo de negócios é reflexo da estratégia adotada pela empresa. Para estes autores, especificamente, a estratégia coincide com o modelo de negócios, de modo que um observador externo pode conhecer a estratégia da empresa, analisando seu modelo de negócios. A diferença substancial entre estratégia e modelo de negócios surge quando o plano de ação da empresa exige modificações no modelo de negócios (mudanças nas políticas de ativos e/ou de governança). Quando for este o caso, estratégia e modelo de negócios não coincidem, independentemente de as modificações do modelo de negócios envolvidas serem substanciais ou de pequeno porte.

O modelo de negócios e a estratégia abordam questões semelhantes, mas em diferentes camadas de negócios. O modelo de negócios é o nível intermediário entre a estratégia e sua implementação por meio dos processos, conforme se pode visualizar na Figura 14; é a camada na qual se define como capturar valor, ou seja, como a empresa ganha dinheiro por meio da entrega de propostas de valor definida por Osterwalder (2004, p. 43) como "overall view of a 
company's bundle of products and services that are value to the customer" ${ }^{\text {, }}$, relações com clientes e redes de valor que contêm as diferentes atividades realizadas pela empresa para entregar produtos de baixo custo ou diferenciados (OSTERWALDER, 2004).

Figura 14 - Camadas do negócio

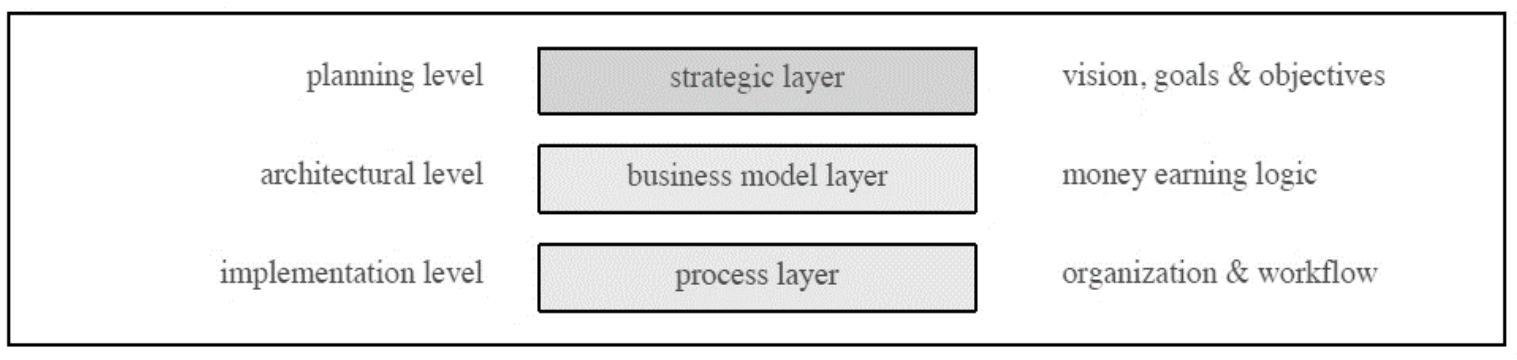

Fonte: OSTERWALDER, 2004, p. 14.

Timmers (1998), por outro lado, define modelo de negócios como:

- Uma arquitetura para o produto, serviço e os fluxos de informação, incluindo uma descrição dos vários atores de negócios e seus papéis;

- A descrição dos benefícios potenciais para os vários atores de negócios;

- A descrição das fontes de receitas.

Além disso, Timmers (1998) também propõe uma abordagem sistemática para identificar arquiteturas para modelos de negócios que pode ser baseada na desconstrução e reconstrução da cadeia de valores possíveis, identificando os elementos que a compõem e as formas de integração de informações ao longo da mesma.

Por fim, Adner (2006) traz o conceito de cadeia de valores e integração entre os diferentes atores do ecossistema como responsável pelo sucesso de uma inovação por meio da avaliação de riscos, caracterizando-os como: adoção, coinovação e execução. Esses riscos precisam ser avaliados e considerados antes da implementação da inovação, pois impactam no desenho do modelo de negócios escolhido.

\footnotetext{
1 "Visão geral do pacote de produtos e serviços de uma empresa que têm valor para o cliente" (OSTERWALDER, 2004, p. 43, tradução livre da autora).
} 


\subsubsection{Desenvolvimento de Modelos de Negócios}

A escolha de um modelo de negócios define a arquitetura da organização, bem como a sua expansão. Assim, o desenvolvimento de modelos de negócios não pode ser explicado simplesmente pela introdução de um novo produto ou serviço, pois há um novo modelo de fazer negócios (FRANKENBERGER et al., 2013).

O papel do modelo de negócios é prover uma estrutura coerente que tenha relação com a tecnologia e a converta em produtos e serviços desejáveis pelos consumidores e economicamente viáveis, visando a atendê-los, assim como a atender aos mercados e a obter resultados econômicos satisfatórios. Ou seja, o papel do modelo de negócios é estabelecer o elo entre o desenvolvimento da tecnologia e a criação de valor econômico. Seu papel final para inovação é certificar-se de que a tecnologia entrega valor para o consumidor (CHESBROUGH; ROSENBLOOM, 2002).

Porter (1999) classifica as empresas essencialmente entre líderes de custos e de diferenciais, ou seja, uma empresa pode ser altamente competitiva ao investir em reduções de custo por meio de economias de escala ou de aprendizagem ou ao optar pela busca de vantagem competitiva por meio da diferenciação de suas ofertas, criando algo único no âmbito de toda a indústria. Assim, o modelo de negócio das empresas pode ser com foco em baixo custo ou com foco em diferenciação. Timmers (1998) classificou os modelos de negócios em função do grau de inovação e de integração. O primeiro diz respeito à variação da forma tradicional de fazer negócios para formas mais inovadoras, por exemplo, por meio da externalização de funções anteriormente realizadas no interior de uma empresa, que passa a ser oferecida em um ambiente digital proporcionado pela Internet ou oferecendo funções que não existiam até então. Por outro lado, o grau de integração abrange a extensão da integração de funções, que vão desde uma única função à plena funcionalidade integrada, por exemplo, à integração da cadeia de valor.

De qualquer forma, diferentes modelos de negócios implicam em um conjunto diferente de atividades, bem como em recursos e capacidades para realizá-las. Cada escolha implicará no potencial de desempenho do empreendimento - que afetará as necessidades de investimentos de capital, os preços aplicados e as margens de ganho, e, talvez mais importante, os clientes e os concorrentes com os quais a nova empresa terá que lidar (ZOTT; AMIT, 2010). Frankenberger e colaboradores (2013) propõem uma estrutura baseada em quatro componentes para guiar o desenvolvimento de modelo de negócios e seus principais desafios, conforme ilustra a Figura 15. 
Figura 15 - A estrutura 4I's: Fases do processo de inovação de modelo de negócios e seus principais desafios

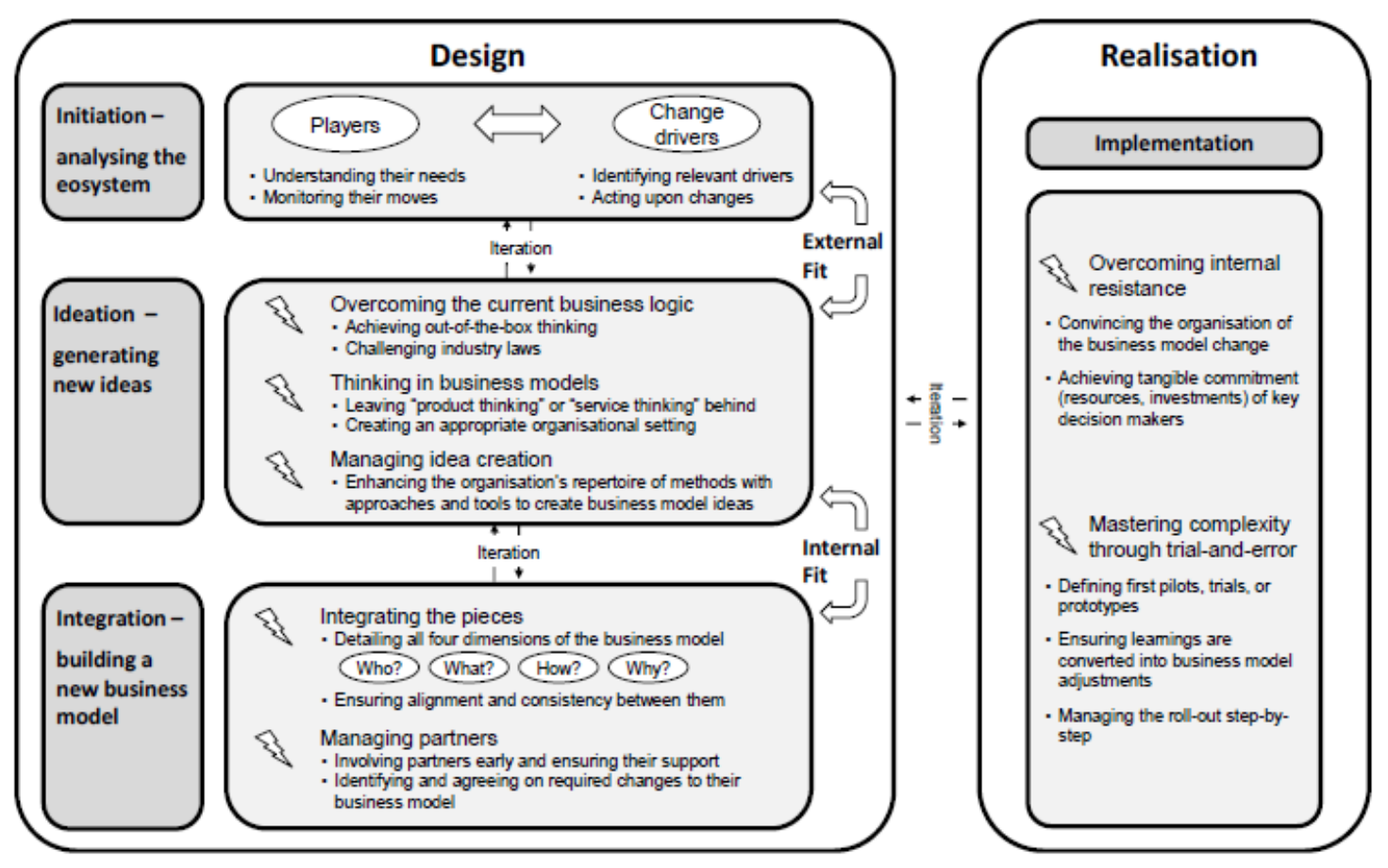

Fonte: FRANKENBERGER et al., 2013, p. 266.

A estrutura dos quatro I’s descreve os estágios do processo de inovação em modelos de negócios, contemplando cada fase. Resumidamente, são eles:

- Iniciação: concentra-se na análise do ecossistema;

- Ideação: refere-se à geração de novas ideias;

- Integração: trata-se da construção de um novo modelo de negócios;

- Implementação: concentra-se na realização do novo modelo comercial.

Johnson, Christensen e Kagermann (2008) consideram o modelo de negócios com quatro elementos interligados e, em conjunto, criam e entregam valor, a saber:

- Proposta de valor para o cliente: como criar valor para o cliente;

- Fórmula do lucro: como a empresa cria valor para si ao criar valor para o cliente; 
- Recursos chaves: quais ativos como pessoas, tecnologia, produtos, instalações, equipamentos, canais e marca são essenciais para a entrega da proposta de valor;

- Processos chaves: quais processos operacionais (treinamento, desenvolvimento, fabricação, orçamento, planejamento, vendas e serviços) e gerenciais (regras, métricas e normas) são necessários para fornecer valor a uma empresa.

A Figura 16 ilustra a interação desses quatro elementos de um modelo de negócios bemsucedido.

Figura 16 - Elementos de um modelo de negócios bem-sucedido

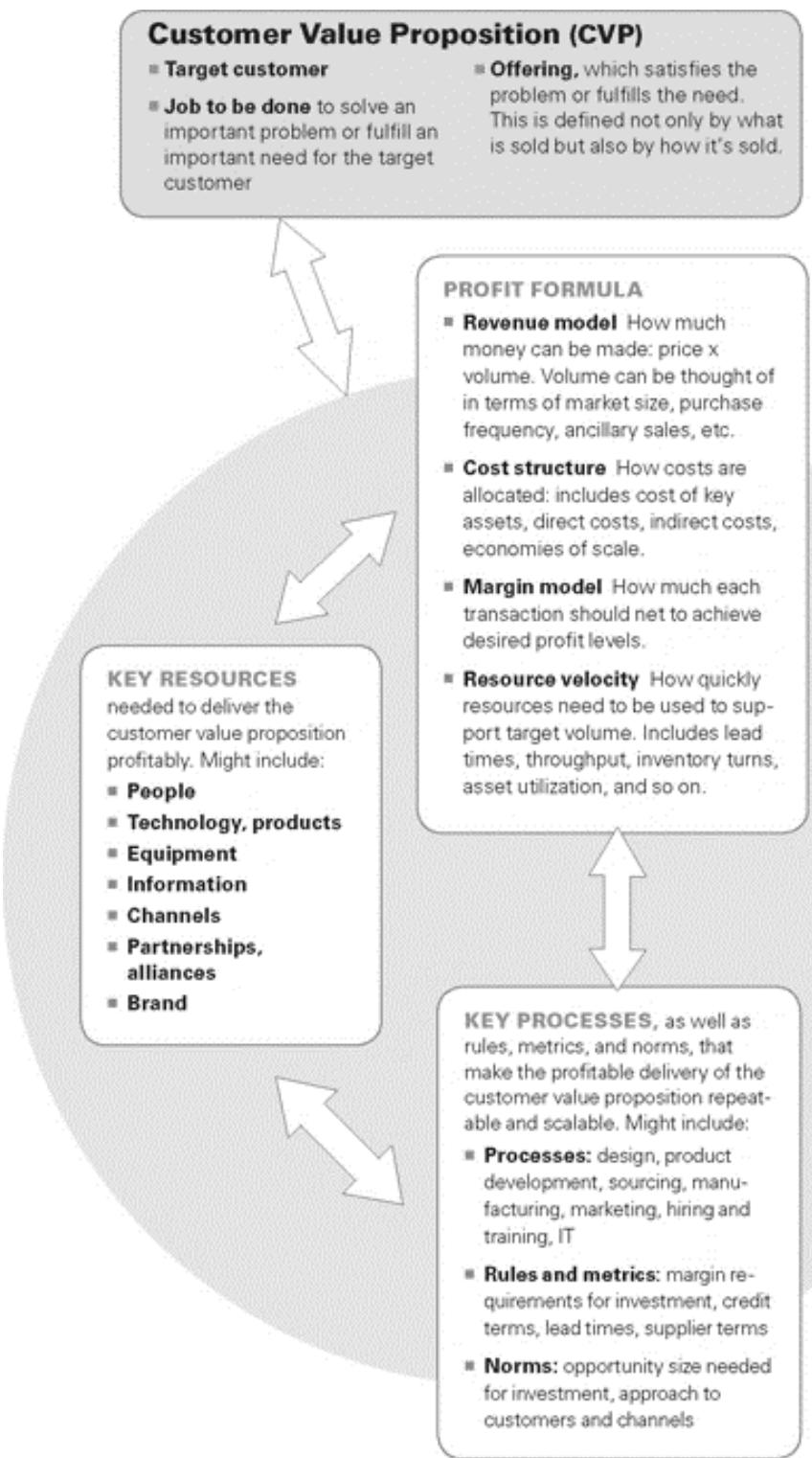

Fonte: JOHNSON; CHRISTENSEN; KAGERMANN, 2008, p. 62. 
Segundo Johnson, Christensen e Kagermann (2008), toda empresa de sucesso opera de acordo com um modelo de negócios efetivo. Ao identificar sistematicamente todos os elementos, os executivos podem entender como o modelo cumpre uma proposta de valor de forma lucrativa, usando recursos e processos chaves. Com esse entendimento, eles podem, então, julgar o que é preciso fazer para construir um novo modelo de negócios.

Influenciado pelo Balance Score Card, de Kaplan e Norton (1992), Osterwalder (2004) adota uma estrutura que enfatiza as quatro áreas principais que o modelo de negócios deve oferecer:

- Produtos: Qual o negócio no qual a empresa está inserida? Quais são os produtos e as proposições de valor oferecidos ao mercado?

- Interface do cliente: Quem são os clientes alvo da empresa? Como eles oferecem produtos e serviços, e como eles constroem um forte relacionamento entre si?

- Gestão de infraestrutura: Como a empresa, de forma eficiente, executa/cuida da infraestrutura ou de questões logísticas, com quem e com que tipo de empresa em rede?

- Aspectos financeiros: Qual é o modelo de receita, a estrutura de custos e os negócios de sustentabilidade?

Figura 17 - Características de um modelo de negócios

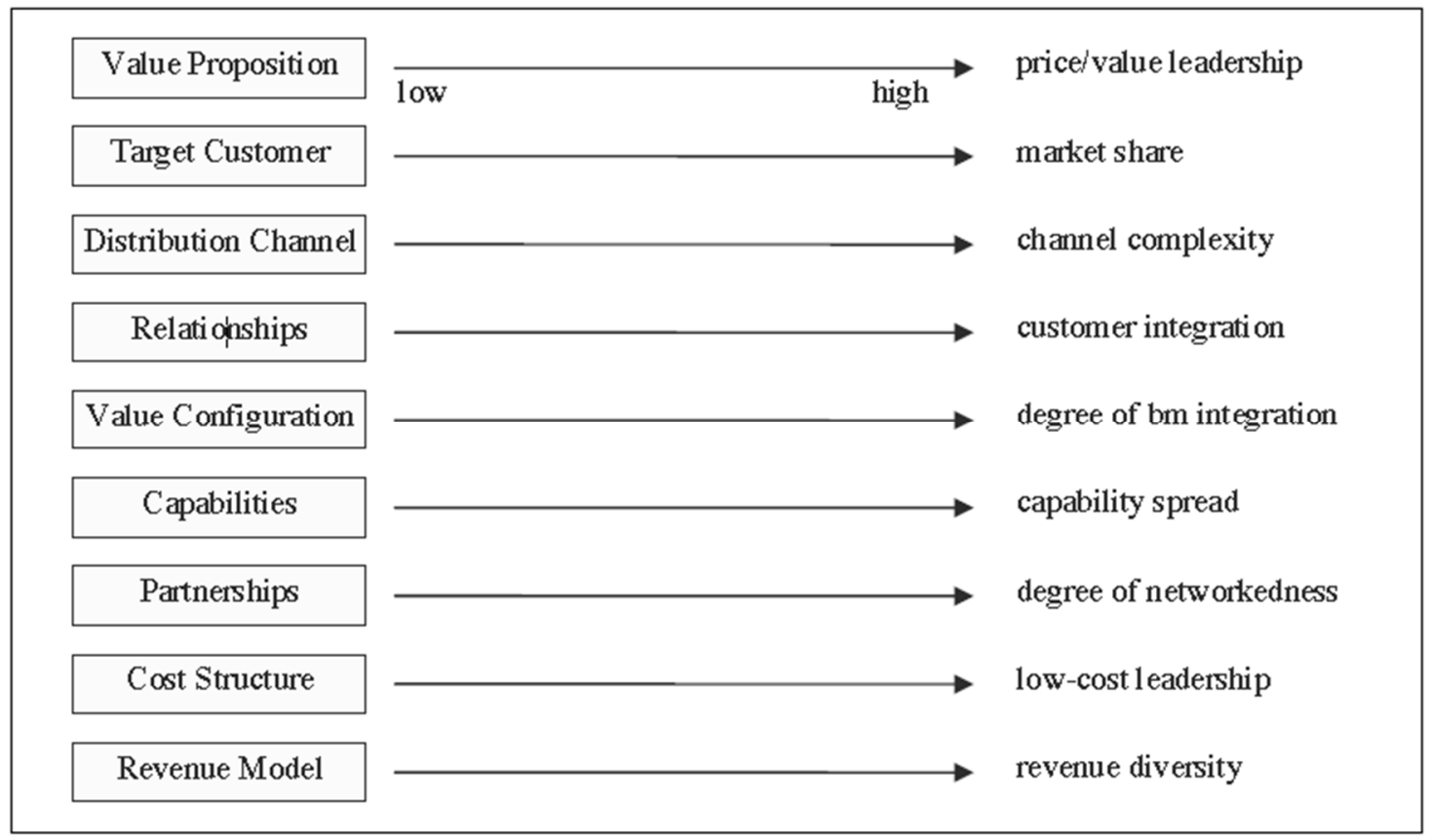

Fonte: OSTERWALDER, 2004, p. 157. 
As nove características de um modelo de negócio apontadas por Osterwalder (2004) evoluíram para o Business Model Canvas ou em tradução livre, "quadro de modelo de negócios", proposto por Osterwalder e Pigner (2010), que permite de uma maneira visual desenvolver ou esboçar modelos de negócio. Conforme Figura 18, no Canvas as quatro áreas definidas anteriormente evoluíram para oferta (oferta e valor), cliente (segmentos de clientes, relacionamento e canais), infraestrutura (parceiros-chaves, atividades-chaves e recursoschaves) e finanças (fontes de receitas e estrutura de custos).

Figura 18 - Business Model Canvas

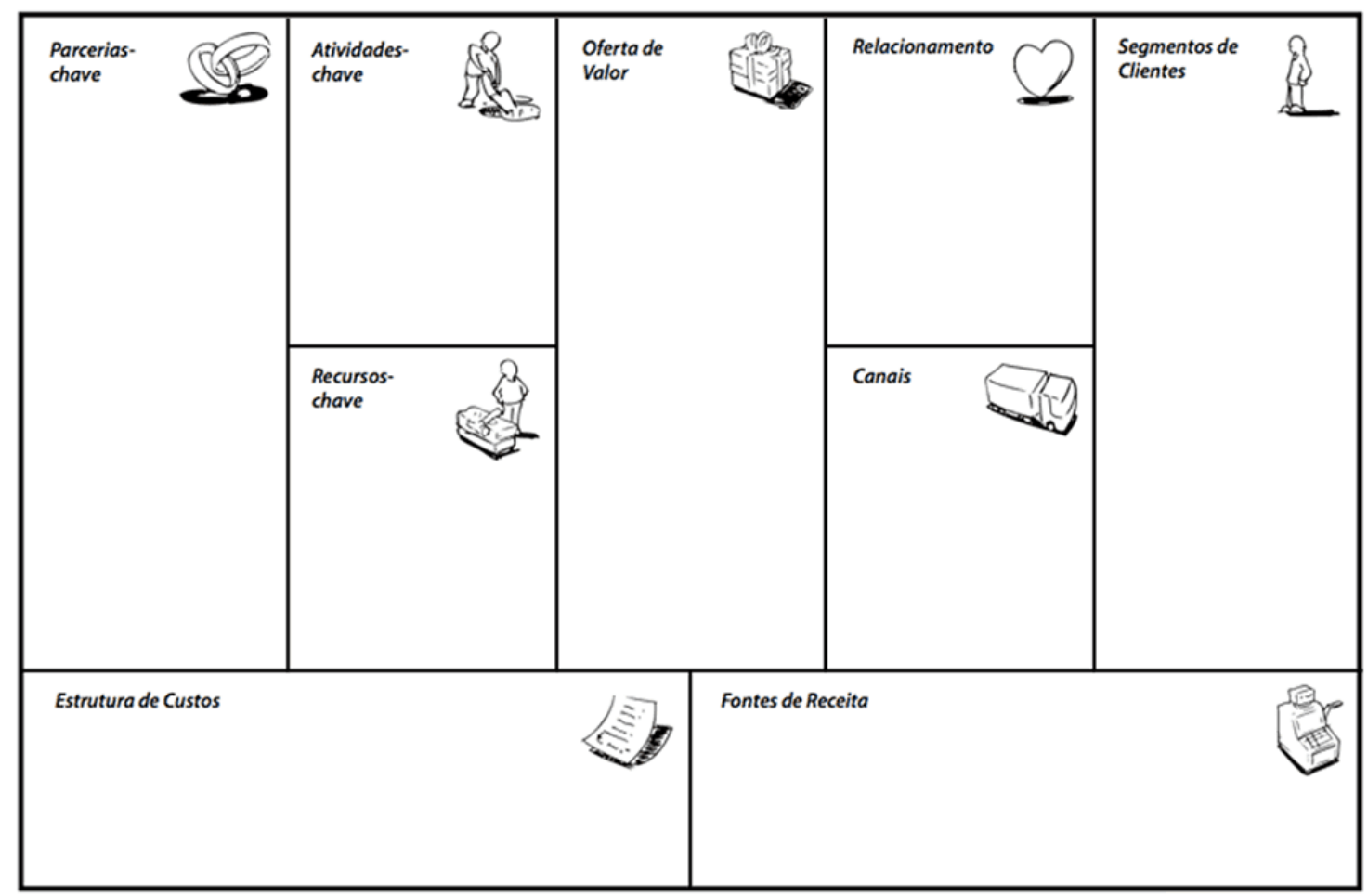

Fonte: Osterwalder e Pigneur (2010)

Criar um modelo de negócios é semelhante a escrever uma nova história que pode ser interpretada pelos sete primeiros eixos propostos por Osterwalder (2004), como ilustrado na Figura 17. Em algum nível, todas as novas histórias são variações das antigas. Da mesma forma, todos os modelos de negócios são variações da cadeia de valor genérica de todas as empresas. No entanto, os modelos de negócios podem falhar ou porque a história criada não é suficientemente boa ou porque os resultados financeiros obtidos não são satisfatórios para a 
empresa. Quando um novo modelo altera a indústria de uma economia e é difícil de replicar, pode por si só instituir uma forte vantagem competitiva (MAGRETTA, 2002).

O desenho do modelo de negócios é uma decisão fundamental para um empreendedor que cria uma nova empresa e é, talvez, a tarefa mais difícil para gerentes gerais encarregados de repensar o seu modelo anterior, para tornara empresa preparada para o futuro (ZOTT; AMIT, 2010). Assim, conforme Chesbrough (2010), as organizações precisam identificar líderes internos para a mudança e, simultaneamente, a cultura da organização precisa encontrar formas de abraçar o novo modelo e de manter a eficiência do modelo atual até que tudo esteja pronto para a completa implantação.

Com o novo modelo de negócios definido, em geral, as empresas encontram grandes dificuldades em mudar o modelo implementado (TEECE, 2010). Ries (2011) acredita que, havendo predisposição para mudar a filosofia de gestão, organizações consolidadas podem balancear as necessidades de atender aos consumidores já existentes com os desafios de buscar novos mercados, novos consumidores e modelo de negócios.

Nessa relação, apesar de os gestores e a própria organização, por vezes, reconhecerem o modelo de negócios que trará inovação, seu desenvolvimento encontra resistência devido a conflitos com o negócio atual ou pela base de configuração dos ativos que suportam o modelo existente (CHESBROUGH, 2010). Nesses casos, a organização precisa gerenciar o relacionamento com o negócio atual, principalmente quando houver concorrência por recursos ou consumidores (EUCHNER; GANGULY, 2014).

Segundo Kelley (2011), em muitas companhias, o empreendedorismo corporativo passa por caminhos cíclicos de apoio entusiástico e de investimento, seguido pela redução de interesse e pelo corte nos programas. Ou seja, o clima empreendedor não é suficiente para que as empresas obtenham sucesso com a inovação (KUEMMERLE, 2006). É preciso que os gestores considerem estratégia, estrutura e processos como um início que necessita de ajustes constantes, na medida em que as condições forem mudando e quanto mais forem ganhando experiência com empreendedorismo (KELLEY, 2011).

O Quadro 2 apresenta um resumo das principais ideias sobre a teoria de modelos de negócios abordada que, assim como a teoria de inovação, direcionou a presente pesquisa de campo, conforme discutido no Capítulo 3: Procedimentos Metodológicos. 
Quadro 2 - Resumo das principais ideias sobre a teoria de modelos de negócios

\begin{tabular}{|c|c|c|}
\hline $\begin{array}{c}\text { Modelos de } \\
\text { Negócios }\end{array}$ & Autores & Ideia Principal \\
\hline \multirow{5}{*}{ Conceito } & Seddon; Lewis (2003) & Abstração da estratégia de uma empresa. \\
\hline & $\begin{array}{l}\text { Casadesus-Masanell e Ricart } \\
(2010)\end{array}$ & $\begin{array}{l}\text { Reflexo da estratégia realizada pela } \\
\text { empresa. }\end{array}$ \\
\hline & Osterwalder (2004) & $\begin{array}{l}\text { Visão da empresa e sua estratégia } \\
\text { interpretadas em propostas de valor, } \\
\text { relações com clientes e redes de valor. }\end{array}$ \\
\hline & Timmers (1998) & Fontes de receitas. \\
\hline & Adner (2006) & Cadeia de valor e integração. \\
\hline \multirow{6}{*}{ Desenvolvimento } & $\begin{array}{l}\text { Johnson; Christensen; } \\
\text { Kagermann(2008) }\end{array}$ & $\begin{array}{l}\text { Proposta de valor, fórmula de lucro, } \\
\text { recursos e processos chaves. }\end{array}$ \\
\hline & Osterwalder (2004) & $\begin{array}{l}\text { Produtos, interface do cliente, gestão de } \\
\text { infraestrutura e aspectos financeiros. }\end{array}$ \\
\hline & Osterwalder e Pigneur (2010) & $\begin{array}{l}\text { Oferta (oferta e valor), cliente (segmentos } \\
\text { de clientes, relacionamento e canais), } \\
\text { infraestrutura (parceiros-chaves, atividades- } \\
\text { chaves e recursos-chaves) e finanças } \\
\text { (fontes de receitas e estrutura de custos). }\end{array}$ \\
\hline & Porter (1999) & Líder em custo ou diferenciação. \\
\hline & Timmers (1998) & Grau de inovação ou de integração. \\
\hline & Frankenberger et al. (2013) & $\begin{array}{l}\text { Abordagem dos 4I's (iniciação, ideação, } \\
\text { integração e implementação). }\end{array}$ \\
\hline
\end{tabular}

Fonte: Quadro elaborado pela autora, com base em diversos autores (2017). 


\section{PROCEDIMENTOS METODOLÓGICOS}

\subsection{MÉTODO DA PESQUISA}

Com o objetivo de entender como as grandes empresas ou as multinacionais inovam e desenvolvem novos negócios para se manterem competitivas, foi realizado um estudo exploratório de natureza qualitativa com especialistas. Cabe destacar que o estudo exploratório busca familiarizar-se com o fenômeno e fazer uma imersão inicial no tema (SAMPIERI; COLLADO; LUCIO, 2006). Ademais, segundo Selltiz e colaboradores (1974), um estudo exploratório pode aumentar o conhecimento acerca do fenômeno ou da situação, bem como estabelecer prioridades para futuras pesquisas.

A Figura 19 ilustra o procedimento metodológico abordado no presente estudo exploratório, que contou também com fontes de pesquisa (externas e internas das organizações analisadas) e com dados primários e secundários (primários, por meio de entrevistas em profundidade; e secundários por meio de relatórios de investidores e websites). Importante ressaltar que os dados secundários foram utilizados, principalmente, como base preparatória para as entrevistas, a fim de obter um conhecimento prévio sobre a possibilidade de atuação dos especialistas entrevistados nas empresas selecionadas. Essa abordagem sustenta-se na visão de Malhotra (2011), que considera a análise de dados secundários e a pesquisa qualitativa como importantes procedimentos da pesquisa exploratória.

Figura 19 - Procedimentos metodológicos do presente estudo

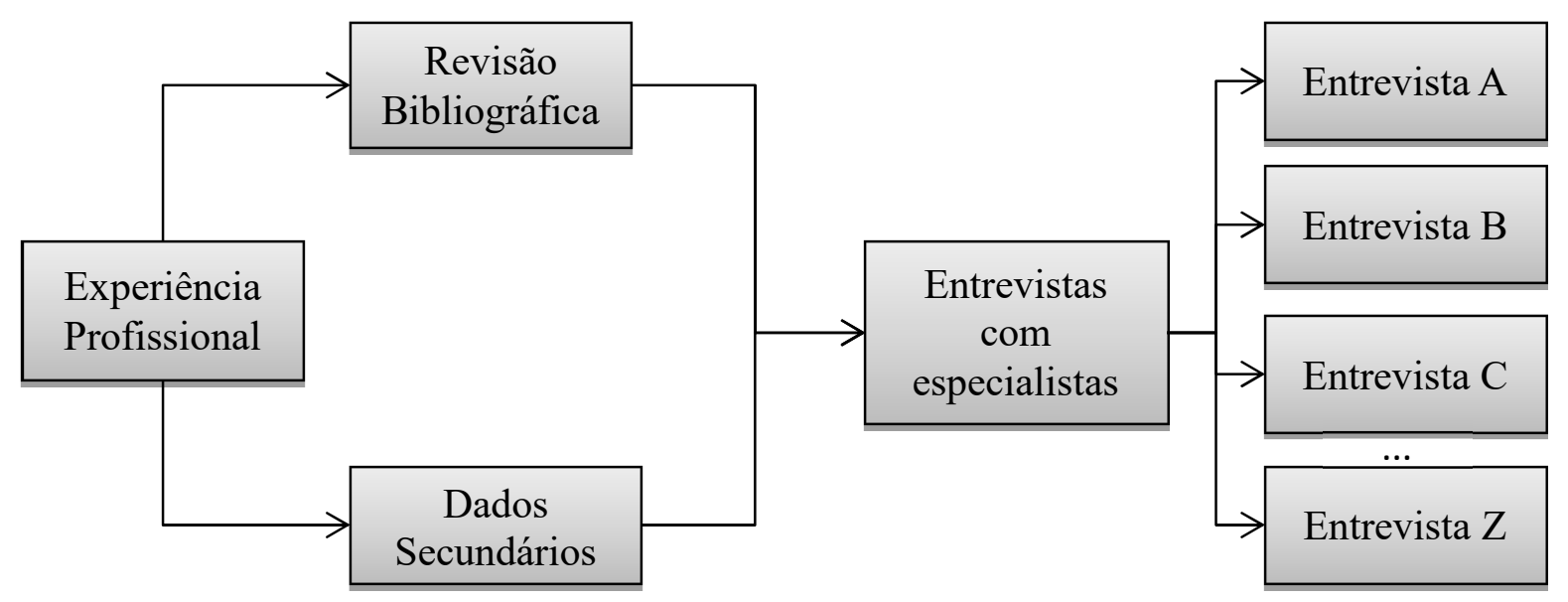

Fonte: Diagrama elaborado pela autora (2017). 


\subsection{PREPARAÇÃO PARA A PESQUISA DE CAMPO}

Nas ciências sociais empíricas, a entrevista qualitativa é a metodologia de coleta amplamente empregada (BAUER; GASKEL, 2002, p. 64). Assim, a pesquisa de campo deste trabalho foi realizada por meio da técnica de entrevistas em profundidade.

Apesar de o presente estudo ser exploratório por meio de entrevistas com especialistas, elaborou-se um protocolo de pesquisa, com as seções detalhadas a seguir, visando a garantir certa padronização nas abordagens e nas entrevistas realizadas.

- Visão geral do estudo: declaração sobre o objetivo do projeto, questões do estudo, contexto no qual o estudo foi desenvolvido e $e$-mails ou mensagens via rede social LinkedIn enviadas para os especialistas das grandes empresas selecionadas ${ }^{2}$.

- Procedimento de campo: ênfase nas principais tarefas relacionadas com a coleta de dados.

- Questões do roteiro: informações para ajudar a pesquisadora no momento da coleta de dados, os motivos de cada uma das questões, a lista de fontes prováveis de evidências e planilha para auxiliar na coleta de dados.

O protocolo desta pesquisa exploratória, apresentado no Quadro 3 a seguir, beneficiouse do conteúdo descrito no Capítulo 1 e de uma carta de apresentação enviada por meio eletrônico (e-mail ou mensagem via rede social LinkedIn) para estabelecer o primeiro contato com os especialistas entrevistados.

Quanto a isso, estabelecer o contato com esses especialistas para a realização das entrevistas foi uma tarefa difícil, pois foi preciso se adaptar às agendas dos respondentes e se adequar ao ambiente organizacional, uma vez que a coleta de dados primários, na maioria das vezes, ocorria durante o expediente de trabalho. Assim, estabelecer os procedimentos de campo que orientaram a pesquisa, garantiram imparcialidade e similaridade entre as entrevistas realizadas.

Importante ressaltar que todas as entrevistas foram gravadas com consentimento dos entrevistados ${ }^{3}$ para posterior transcrição e análise.

\footnotetext{
${ }^{2}$ Os e-mails e mensagens enviadas estão em posse da autora e não foram divulgados para manter a privacidade dos entrevistados e das empresas.

${ }^{3}$ A autorização verbal foi dada por cada participante durante as entrevistas e encontram-se em poder da autora.
} 
Quadro 3 - Protocolo de Pesquisa

\begin{tabular}{|l|l|l|}
\hline \multicolumn{1}{|c|}{ Elemento } & \multicolumn{1}{|c|}{ Seções } & \multicolumn{1}{c|}{ Característica } \\
\hline $\begin{array}{l}\text { Visão geral do } \\
\text { estudo }\end{array}$ & $\begin{array}{l}\text { Objetivo do } \\
\text { estudo }\end{array}$ & $\begin{array}{l}\text { Investigar como a inovação por meio do desenvolvimento de } \\
\text { modelo de negócios contribui para a competitividade de } \\
\text { grandes empresas. }\end{array}$ \\
\hline $\begin{array}{l}\text { Procedimentos } \\
\text { de campo }\end{array}$ & $\begin{array}{l}\text { Unidade de } \\
\text { análise }\end{array}$ & $\begin{array}{l}\text { Relacionar inovação nas empresas e desenvolvimento de } \\
\text { novos negócios para potencializar a vantagem competitiva. }\end{array}$ \\
\cline { 2 - 4 } & $\begin{array}{l}\text { Período da } \\
\text { coleta }\end{array}$ & 2016 e 2017. \\
\cline { 2 - 4 } & Amostragem & $\begin{array}{l}\text { Especialistas que trabalham em grandes empresas } \\
\text { multinacionais reconhecidas como inovadoras e que atuam no } \\
\text { desenvolvimento de modelo de negócios e inovação no Brasil. }\end{array}$ \\
\hline estudo & $\begin{array}{l}\text { Baseadas nos } \\
\text { objetivos } \\
\text { específicos }\end{array}$ & $\begin{array}{l}\text { Apresentar o entendimento de inovação e modelos de } \\
\text { negócios para os especialistas que atuam nas grandes } \\
\text { empresas. } \\
\text { Descrever a estratégia de inovação adotada pelas empresas e } \\
\text { como esta se relaciona com o desenvolvimento de modelos } \\
\text { de negócios. }\end{array}$ \\
\cline { 2 - 4 } & $\begin{array}{l}\text { Identificar os tipos de inovação nos quais os especialistas } \\
\text { que atuam nas empresas estão envolvidos. } \\
\text { Identificar as motivações e barreiras enfrentadas pelos } \\
\text { especialistas na jornada de implantação da inovação voltada } \\
\text { para o desenvolvimento de modelos de negócios. }\end{array}$ \\
\hline
\end{tabular}

Fonte: Quadro elaborado pela autora (2017).

Os conteúdos dos capítulos teóricos alimentaram as questões do roteiro (apresentado no Apêndice A), principalmente no que diz respeito aos objetivos secundários da pesquisa. Além disso, a matriz de amarração - Quadro 4 -, agregada às fontes de possíveis evidências oriundas do referencial teórico, serviu de base para a planilha de coleta de dados, pois permitiu cruzar os objetivos da pesquisa com as questões de estudo e com fontes de evidências.

Sintetizando, a matriz de amarração metodológica, apresentada no Quadro 4, constitui uma representação matricial em que se apresentam as conexões e os vínculos entre modelo, objetivos, questões e/ou hipóteses de pesquisa, além dos procedimentos e técnicas de análise de dados (TELLES, 2001). 
Quadro 4 - Matriz de Amarração Metodológica

\begin{tabular}{|c|c|c|c|}
\hline $\begin{array}{c}\text { Objetivos da } \\
\text { Pesquisa }\end{array}$ & $\begin{array}{c}\text { Fontes de } \\
\text { Evidências }\end{array}$ & Questões da Pesquisa & Resultados Esperados \\
\hline $\begin{array}{l}\text { 1. Apresentar o } \\
\text { entendimento de } \\
\text { inovação e } \\
\text { modelos de } \\
\text { negócios a partir } \\
\text { da percepção de } \\
\text { especialistas que } \\
\text { atuam em } \\
\text { grandes } \\
\text { organizações. }\end{array}$ & $\begin{array}{l}\text { Drucker (2002), } \\
\text { Porter (1999), } \\
\text { Schumpeter (1997), } \\
\text { Von Hippel (2005); } \\
\text { Casadesus-Masanell } \\
\text { e Ricart (2010), } \\
\text { Osterwalder (2004), } \\
\text { Seddon e Lewis } \\
\text { (2003) e Timmers } \\
\text { (1998). }\end{array}$ & $\begin{array}{l}\text { - O que é inovação? } \\
\text { - O que é modelo de } \\
\text { negócios? } \\
\text { - Qual a importância de } \\
\text { inovação e modelo de } \\
\text { negócios para a } \\
\text { empresa? }\end{array}$ & $\begin{array}{l}\text { - Verificar o entendimento das } \\
\text { empresas referente aos temas } \\
\text { de estudo. } \\
\text { - Identificar gaps entre } \\
\text { literatura e prática. } \\
\text { - Entender a importância } \\
\text { estratégica do desenvol- } \\
\text { vimento de modelo de } \\
\text { negócios e inovação para a } \\
\text { competitividade empresarial. }\end{array}$ \\
\hline $\begin{array}{l}\text { 2. Descrever } \\
\text { como os } \\
\text { especialistas } \\
\text { conduzem a } \\
\text { gestão de } \\
\text { inovação e como } \\
\text { esta se relaciona } \\
\text { com o } \\
\text { desenvolvimento } \\
\text { de modelos de } \\
\text { negócios nas } \\
\text { grandes } \\
\text { organizações. }\end{array}$ & $\begin{array}{l}\text { Cooper (1986, } \\
\text { 1994), Birkinshaw e } \\
\text { Hamel (2008), } \\
\text { Chesbrough e } \\
\text { Rosenbloom (2002), } \\
\text { COTEC (1998), } \\
\text { Johnson e } \\
\text { colaboradores } \\
\text { (2008), Jonash e } \\
\text { Sommerlatte (2001), } \\
\text { Osterwalder (2004), } \\
\text { Ries (2011), Tidd; } \\
\text { Bessant: Pavitt } \\
\text { (2008), Timmers } \\
\text { (1998) e Veryzer } \\
\text { (1998). }\end{array}$ & $\begin{array}{l}\text { - Qual o modelo de } \\
\text { inovação da empresa? } \\
\text { - Há um processo } \\
\text { estabelecido para } \\
\text { desenvolver modelo de } \\
\text { negócios? } \\
\text { - Quem participa do } \\
\text { processo? } \\
\text { - Existe uma área } \\
\text { responsável? }\end{array}$ & $\begin{array}{l}\text { Descrever como as empresas } \\
\text { estão estruturadas para } \\
\text { inovar e para desenvolver } \\
\text { modelos de negócio, em } \\
\text { busca da competitividade. }\end{array}$ \\
\hline $\begin{array}{l}\text { 3. Identificar os } \\
\text { tipos de } \\
\text { inovação nos } \\
\text { quais os } \\
\text { especialistas que } \\
\text { trabalham em } \\
\text { grandes } \\
\text { organizações } \\
\text { estão } \\
\text { envolvidos. }\end{array}$ & $\begin{array}{l}\text { Abernathy e Clark } \\
\text { (1985), Christensen } \\
\text { (2000), Davila, } \\
\text { Epstein e Shelton } \\
\text { (2005), Manual de } \\
\text { Oslo (1997). }\end{array}$ & $\begin{array}{l}\text { - Quais iniciativas de } \\
\text { inovação são realizadas? } \\
\text { - Quais iniciativas } \\
\text { implementadas } \\
\text { aumentaram a } \\
\text { competitividade? } \\
\text { - Quais iniciativas de } \\
\text { inovação criaram } \\
\text { modelo de negócios? }\end{array}$ & $\begin{array}{l}\text { - Mapear o foco de inovação } \\
\text { nas empresas e como elas se } \\
\text { relacionam com o } \\
\text { desenvolvimento de modelo } \\
\text { de negócios. }\end{array}$ \\
\hline $\begin{array}{l}\text { 4. Identificar as } \\
\text { motivações e as } \\
\text { barreiras } \\
\text { enfrentadas na } \\
\text { jornada de } \\
\text { implantação da } \\
\text { inovação voltada } \\
\text { para o } \\
\text { desenvolvimento } \\
\text { de modelos de } \\
\text { negócios. }\end{array}$ & $\begin{array}{l}\text { Birkinshaw e Hamel } \\
\text { (2008), } \\
\text { Christensen (2000), } \\
\text { Drucker (2011), } \\
\text { Kuemmerle (2006), } \\
\text { Kelley (2011), } \\
\text { Teece (2010), } \\
\text { Zott e Amit (2010). }\end{array}$ & $\begin{array}{l}\text { - Quais são os principais } \\
\text { desafios para gerar } \\
\text { inovação e implementar } \\
\text { modelo de negócios? } \\
\text { - Quais são as motivações } \\
\text { e as barreiras que } \\
\text { existem hoje para inovar } \\
\text { buscando o } \\
\text { desenvolvimento de } \\
\text { novo modelo de } \\
\text { negócios? }\end{array}$ & $\begin{array}{l}\text { Entender o que promove e o } \\
\text { que inibe a inovação voltada } \\
\text { ao desenvolvimento de } \\
\text { modelo de negócios. }\end{array}$ \\
\hline
\end{tabular}

Fonte: Quadro Elaborado pela autora (2017), com base em Mazzon (1978, apud 


\subsection{INSTRUMENTO DE COLETA}

Considerando-se que o presente estudo teve como objetivo entender como a inovação por meio do desenvolvimento de modelo de negócios contribui para a competitividade de grandes empresas, a pesquisa qualitativa com especialistas proporcionou uma melhor visão e compreensão do tema. Além disto, também auxiliou no desenvolvimento de uma abordagem adequada ao pesquisador, que se depara com uma situação de incerteza, sem expectativa de resultados conclusivos (MALHOTRA, 2011).

Para atender aos objetivos propostos, os dados foram coletados por meio entrevistas em profundidade, com apoio de roteiro semiestruturado, o que possibilitou entender e analisar como diferentes gestores de grandes empresas estão atuando com inovação e desenvolvimento de modelo de negócios. O Quadro 5 elenca os objetivos da pesquisa e amarra o método e a forma de coleta de dados.

Quadro 5 - Matriz de amarração simplificada

\begin{tabular}{|c|c|c|}
\hline Objetivos da Pesquisa & Método & Coleta de Dados \\
\hline $\begin{array}{l}\text { 1. Apresentar o entendimento de } \\
\text { inovação e modelos de negócios a } \\
\text { partir da percepção de especialistas } \\
\text { que atuam em grandes } \\
\text { organizações. }\end{array}$ & $\begin{array}{l}\text { Pesquisa Qualitativa com líderes } \\
\text { ou gestores de inovação, } \\
\text { considerados neste estudo como } \\
\text { especialistas }\end{array}$ & $\begin{array}{l}\text { - Consulta } \\
\text { Bibliográfica; } \\
\text { - Entrevistas } \\
\text { semiestruturadas. }\end{array}$ \\
\hline $\begin{array}{l}\text { 2. Descrever como os especialistas } \\
\text { conduzem a gestão de inovação e } \\
\text { como esta se relaciona com o } \\
\text { desenvolvimento de modelos de } \\
\text { negócios nas grandes organizações. }\end{array}$ & $\begin{array}{l}\text { Pesquisa Qualitativa com líderes } \\
\text { ou gestores de inovação, } \\
\text { considerados neste estudo como } \\
\text { especialistas. }\end{array}$ & $\begin{array}{l}\text { - Consulta } \\
\text { Bibliográfica; } \\
\text { - Entrevistas } \\
\text { semiestruturadas. }\end{array}$ \\
\hline $\begin{array}{l}\text { 3. Identificar os tipos de } \\
\text { inovação nos quais os especialistas } \\
\text { que trabalham em grandes empresas } \\
\text { estão envolvidos. }\end{array}$ & $\begin{array}{l}\text { Pesquisa Qualitativa com líderes } \\
\text { ou gestores de inovação, } \\
\text { considerados neste estudo como } \\
\text { especialistas. }\end{array}$ & $\begin{array}{l}\text { - Consulta } \\
\text { Bibliográfica; } \\
\text { - Entrevistas } \\
\text { semiestruturadas. }\end{array}$ \\
\hline $\begin{array}{l}\text { 4. Identificar as motivações e } \\
\text { barreiras enfrentadas na jornada de } \\
\text { implantação da inovação voltada } \\
\text { para o desenvolvimento de modelos } \\
\text { de negócios. }\end{array}$ & $\begin{array}{l}\text { Pesquisa Qualitativa com líderes } \\
\text { ou gestores de inovação, } \\
\text { considerados neste estudo como } \\
\text { especialistas. }\end{array}$ & $\begin{array}{l}\text { - Consulta } \\
\text { Bibliográfica; } \\
\text { - Entrevistas } \\
\text { semiestruturadas. }\end{array}$ \\
\hline
\end{tabular}


O estudo foi norteado por um roteiro definido a partir da matriz de amarração metodológica - Quadro 4 - composta por quatro blocos de perguntas que contemplaram 24 questões. Inicialmente, como pré-teste, foram realizadas duas entrevistas, uma presencial e outra via Skype, com profissionais de uma empresa multinacional. A seguir, foram feitos ajustes no roteiro, a fim de tornar a entrevista mais fluida com a inversão de alguns blocos de perguntas. O pré-teste ocorreu em junho de 2016 e a pesquisa de campo foi realizada de novembro de 2016 a abril de $2017^{4}$.

\subsection{SELEÇÃO DOS SUJEITOS SOCIAIS}

A fim de atender aos objetivos deste trabalho, definiram-se como sujeitos sociais, profissionais especialistas que trabalham em grandes empresas multinacionais com inovação ou modelos de negócios. Tais especialistas deveriam atuar em cargos de liderança nas empresas para poder tratar dos temas com propriedade.

Assim, tendo em vista que a presente pesquisa se propôs a investigar como a inovação por meio do desenvolvimento de modelo de negócios contribui para a competitividade de grandes empresas multinacionais, cabe primeiramente definir o que se está entendendo por "grandes empresas" e por "multinacionais".

Considerou-se como "grandes empresas", as que tinham uma receita operacional bruta anual superior a R\$ 300 milhões, segundo critério estabelecido pelo Banco Nacional de Desenvolvimento Econômico e Social (BNDES) (s.d.), como se pode constatar no Quadro 6.

Quadro 6 - Classificação de grande empresa em função da renda operacional bruta anual

\begin{tabular}{|l|l|}
\hline \multicolumn{1}{|c|}{ Classificação } & \multicolumn{1}{c|}{ Receita Operacional Bruta Anual ou Renda Anual } \\
\hline Microempresa & Inferior ou igual a R\$ 360 mil \\
\hline Pequena empresa & Superior a R\$ 360 mil e inferior ou igual a R\$ 3,6 milhões \\
\hline Média empresa & $\begin{array}{l}\text { Superior a R \$ 3,6 milhões e inferior ou igual a R \$ 300 } \\
\text { milhões }\end{array}$ \\
\hline Grande empresa & Superior a R \$ 300 milhões \\
\hline
\end{tabular}

Fonte: Adaptado do Banco Nacional de Desenvolvimento Econômico e Social (BNDES, s.d.).

\footnotetext{
${ }^{4}$ Esse hiato ocorreu devido à licença maternidade da pesquisadora.
} 
Como "multinacional" considerou-se o critério estabelecido pelas Nações Unidas que assim define: "The term "multinational" signifies that the activities of the corporation or enterprise involve more than one nation (...)The activity in question may refer to assets, sales, production, employment, or profits from foreign branches and affiliates" ${ }^{5}$ (UNITED NATIONS, 1973, p. 4).

A seleção dos entrevistados teve como ponto de partida profissionais que trabalham em empresas reconhecidas como inovadoras. Dessa forma, para composição amostral os especialistas foram buscados em organizações multinacionais com base em três rankings de inovação existentes no país que distingue as melhores empresas nesse quesito, considerando as grandes empresas que nos últimos seis anos (2010 - 2015) receberam os seguintes prêmios:

- Best Innovator Brazil: é uma iniciativa global da consultoria A.T. Kearney, que premia e reconhece as empresas mais inovadoras do país, com base em uma metodologia concebida para avaliar e ajudar as empresas no processo de gestão da inovação em cinco frentes (estratégia, cultura e organização, processos, estrutura de suporte e sucesso da inovação).

- Prêmio FINEP (Financiadora de Estudos e Projetos) na categoria Grande Empresa: trata-se de uma iniciativa da própria FINEP, criada para conhecer e divulgar esforços inovadores realizados por empresas, instituições sem fins lucrativos e pessoas físicas, desenvolvidos no Brasil e já inseridos no mercado interno ou externo. Ocorre desde 1998, premiando centenas de empresas, instituições e pessoas físicas. É o mais importante instrumento de estímulo e reconhecimento à inovação no País.

- Prêmio de inovação: é uma iniciativa da Mobilização Empresarial da Inovação (MEI) realizada pelas seguintes instituições: Confederação Nacional da Indústria (CNI), Serviço Brasileiro de Apoio às Micro e Pequenas Empresas (SEBRAE) e Movimento Brasil Competitivo (MBC), com o apoio da Financiadora de Estudos e Projetos (FINEP), Ministério de

\footnotetext{
${ }^{5} \mathrm{O}$ termo "multinacional" significa que as atividades da corporação ou da empresa envolvem mais de uma nação (...). A atividade em questão pode se referir a ativos, vendas, produção, emprego ou lucros de filiais e afiliadas estrangeiras (UNITED NATIONS, 1973, p. 4, tradução livre da autora).
} 
Ciência, Tecnologia, Inovação e Comunicação (MCTIC), Instituto Euvaldo Lodi (IEL) e Serviço Nacional de Aprendizagem Industrial (SENAI).

Cabe esclarecer que, embora a priori o estudo tenha estabelecido como recorte temporal o período de 2010 a 2015, como mencionado, pelo fato de não ter ocorrido premiação por todas as instituições desde 2014, a seleção amostral acabou se restringindo a 2011, 2012 e 2013, por terem sido os anos em que ocorreram simultaneamente as três premiações.

Assim, com base no critério de seleção supramencionado, no Quadro 7 apresenta-se, por ordem alfabética, uma relação das empresas e suas respectivas premiações. Os números mencionados correspondem à quantidade de prêmios que cada qual recebeu no período estabelecido.

Quadro 7 - Relação das empresas selecionadas para análise e quantidade de prêmios que cada qual recebeu entre 2011 e 2013

\begin{tabular}{|l|c|c|c|c|}
\hline \multirow{2}{*}{ EMPRESAS } & \multicolumn{4}{|c|}{ PRÊMIOS } \\
\cline { 2 - 5 } & Best Innovator & Finep & $\begin{array}{c}\text { Prêmio Nacional } \\
\text { de Inovação }\end{array}$ & Total geral \\
\hline Natura & - & 2 & 2 & 4 \\
\hline Weg & - & 3 & 1 & 4 \\
\hline 3M & 2 & - & 1 & 3 \\
\hline Basf & 3 & - & - & 3 \\
\hline Embraer & - & 2 & 1 & 3 \\
\hline Whirlpool & 2 & - & 1 & 3 \\
\hline Brasilata & - & - & 1 & 1 \\
\hline Braskem & - & 1 & - & 1 \\
\hline Coelce & - & - & 1 & 1 \\
\hline Dow & 1 & - & - & 1 \\
\hline Embraco & - & 1 & - & 1 \\
\hline IBM & 1 & - & - & 1 \\
\hline Siemens & - & - & 1 & 1 \\
\hline
\end{tabular}

Fonte: Quadro elaborado pela autora (2017) com base nas premiações $(2011$ - 2013).

Para realizar as entrevistas foram selecionados especialistas, cujas atividades estivessem relacionadas com inovação e possuíssem cargo de liderança dentre as empresas premiadas no período analisado, que constam no Quadro 7. O fato de atuarem em segmentos distintos não comprometeu a análise, pois o objetivo era compreender a percepção de especialistas engajados 
no tema em questão - inovação e modelo de negócios - e, assim, buscar entender semelhanças e diferenças na abordagem de inovação voltada para o desenvolvimento de modelo de negócios em grandes empresas multinacionais.

As entrevistas foram qualitativas, como proposto por Bauer e Gaskell (2002), por destacarem um processo circular e reflexivo. Após a realização de algumas delas, a seleção dos entrevistados poderia, se necessário, ser passível de mudanças, segundo os autores.

Devido à dificuldade de contato com todas as empresas pré-selecionadas, pertencentes ao grupo das mais inovadoras no Brasil de acordo com os prêmios recebidos (que constam no Quadro 7), foi possível realizar a pesquisa em apenas 5 (cinco) delas. Então, como previsto por Bauer e Gaskell (2002), optou-se por manter o perfil pré-estabelecido, ou seja, especialistas cujas atividades abrangesseem inovação e possuíssem cargo de liderança em grandes empresas multinacionais que desenvolvem inovação no Brasil, mais outras 4 (quatro) empresas foram contempladas, totalizando, assim, 9 (nove) empresas analisadas. No total, foram entrevistados 12 (doze) especialistas, 5 (cinco) deles de empresas não pertencentes ao rol das premiadas no período selecionado.

Por questões éticas, não identificamos nem as empresas analisadas e nem os especialistas entrevistados, mas, no Quadro 8, apresentamos, em detalhes, as características de ambos, conforme a classificação setorial da BM\&FBOVESPA (2017) e a classificação subsetorial de inovação proposta por Arthur D. Little, em seu estudo Global Innovation Survey (2005), ilustrado na Figura 1. As informações apresentadas sobre as empresas, tais como nacionalidade, receita e a presença em outros países, foram coletadas nos websites e nos relatórios anuais de 2016, publicados por cada organização respectivamente. 
Quadro 8 - Características dos especialistas entrevistados e das respectivas multinacionais para as quais trabalham

\begin{tabular}{|c|c|c|c|c|c|c|c|c|}
\hline \multirow{2}{*}{ 昰 } & \multicolumn{4}{|c|}{$\begin{array}{c}\text { Características dos Especialistas } \\
\text { Entrevistados }\end{array}$} & \multicolumn{4}{|c|}{$\begin{array}{c}\text { Características das Empresas Multinacionais } \\
\text { onde trabalham }\end{array}$} \\
\hline & שึ & 胥 & 胥 & 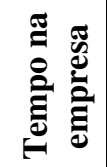 & 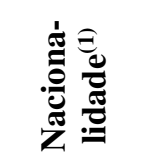 & 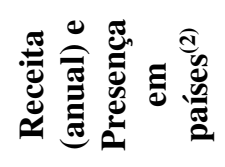 & 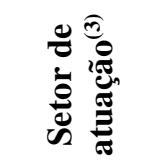 & 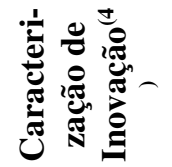 \\
\hline 1 & $\begin{array}{l}\text { Gerente de } \\
\text { inovação e } \\
\text { gestão do } \\
\text { conheci- } \\
\text { mento }\end{array}$ & $\begin{array}{l}43 \\
\text { anos }\end{array}$ & $\begin{array}{l}\text { Engenharia } \\
\text { Química } \\
\text { (graduação) } \\
\text { Pós-graduação e } \\
\text { MBA }\end{array}$ & $\begin{array}{l}7 \\
\text { anos }\end{array}$ & $\begin{array}{l}\text { Brasi- } \\
\text { leira }\end{array}$ & $\begin{array}{l}\mathrm{R} \$ 55 \text { bilhões } \\
\text { Presente em } \\
\text { mais de } 10 \\
\text { países }\end{array}$ & $\begin{array}{l}\text { Materiais } \\
\text { básicos }\end{array}$ & $\begin{array}{l}\text { Inovadores } \\
\text { conser- } \\
\text { vadores }\end{array}$ \\
\hline 2 & $\begin{array}{l}\text { Gerente de } \\
\text { P\&D }\end{array}$ & $\begin{array}{l}46 \\
\text { anos }\end{array}$ & $\begin{array}{l}\text { Engenharia } \\
\text { Química } \\
\text { (graduação) } \\
\text { Pós-graduação e } \\
\text { MBA }\end{array}$ & $\begin{array}{l}23 \\
\text { anos }\end{array}$ & \multirow[t]{2}{*}{$\begin{array}{l}\text { Euro- } \\
\text { peia }\end{array}$} & \multirow[t]{2}{*}{$\begin{array}{l}€ 57 \text { bilhões } \\
\text { Presente em } \\
\text { mais de } 80 \\
\text { países }\end{array}$} & \multirow[t]{2}{*}{$\begin{array}{l}\text { Materiais } \\
\text { básicos }\end{array}$} & \multirow[t]{2}{*}{$\begin{array}{l}\text { Inovadores } \\
\text { conser- } \\
\text { vadores }\end{array}$} \\
\hline 3 & $\begin{array}{l}\text { Coorde- } \\
\text { nador de } \\
\text { Novos } \\
\text { Negócios } \\
\end{array}$ & $\begin{array}{l}31 \\
\text { anos }\end{array}$ & $\begin{array}{l}\text { Administração } \\
\text { (graduação) } \\
\text { Pós-graduação }\end{array}$ & $\begin{array}{l}10 \\
\text { anos }\end{array}$ & & & & \\
\hline 4 & $\begin{array}{l}\text { Head de } \\
\text { Inovação } \\
\text { Corporativa }\end{array}$ & $\begin{array}{l}42 \\
\text { anos }\end{array}$ & $\begin{array}{l}\text { Engenharia de } \\
\text { Produção } \\
\text { Mestrado e } \\
\text { doutorado }\end{array}$ & $\begin{array}{l}17 \\
\text { anos }\end{array}$ & $\begin{array}{l}\text { Brasi- } \\
\text { leira }\end{array}$ & $\begin{array}{l}\mathrm{R} \$ 21 \text { bilhões } \\
\text { Presente em } \\
\text { mais de } 100 \\
\text { países }\end{array}$ & $\begin{array}{l}\text { Bens } \\
\text { indus- } \\
\text { triais }\end{array}$ & $\begin{array}{l}\text { Inovadores } \\
\text { de alta } \\
\text { intensidade }\end{array}$ \\
\hline 5 & $\begin{array}{l}\text { Gerente de } \\
\text { Marketing }\end{array}$ & $\begin{array}{l}34 \\
\text { anos }\end{array}$ & $\begin{array}{l}\text { Engenharia de } \\
\text { Produção } \\
\text { (graduação) } \\
\text { Pós-graduação e } \\
\text { MBA }\end{array}$ & $\begin{array}{l}10 \\
\text { anos }\end{array}$ & \multirow[t]{2}{*}{$\begin{array}{l}\text { Norte- } \\
\text { ameri- } \\
\text { cana }\end{array}$} & \multirow[t]{2}{*}{$\begin{array}{l}\text { US\$ } 21 \\
\text { bilhões } \\
\text { Presente em } \\
\text { mais de } 70 \\
\text { países }\end{array}$} & \multirow[t]{2}{*}{$\begin{array}{l}\text { Consumo } \\
\text { cíclico }\end{array}$} & \multirow[t]{2}{*}{$\begin{array}{l}\text { Inovadores } \\
\text { conser- } \\
\text { vadores }\end{array}$} \\
\hline 6 & $\begin{array}{l}\text { Líder de } \\
\text { Projetos de } \\
\text { Inovação }\end{array}$ & $\begin{array}{l}33 \\
\text { anos }\end{array}$ & $\begin{array}{l}\text { Engenharia de } \\
\text { Materiais } \\
\text { (graduação) } \\
\text { MBA }\end{array}$ & $\begin{array}{l}10 \\
\text { anos }\end{array}$ & & & & \\
\hline 7 & $\begin{array}{l}\text { Head de } \\
\text { Marketing } \\
\text { Corporativo }\end{array}$ & $\begin{array}{l}46 \\
\text { anos }\end{array}$ & $\begin{array}{l}\text { Administração e } \\
\text { Publicidade } \\
\text { (graduação) } \\
\text { Pós-graduação }\end{array}$ & $\begin{array}{l}22 \\
\text { anos }\end{array}$ & $\begin{array}{l}\text { Norte- } \\
\text { ameri- } \\
\text { cana }\end{array}$ & $\begin{array}{l}\text { US\$ } 30 \\
\text { bilhões } \\
\text { Presente em } \\
\text { mais de } 70 \\
\text { países } \\
\end{array}$ & $\begin{array}{l}\text { Finan- } \\
\text { ceiro e } \\
\text { outros }\end{array}$ & $\begin{array}{l}\text { Inovadores } \\
\text { conser- } \\
\text { vadores }\end{array}$ \\
\hline 8 & $\begin{array}{l}\text { Head de } \\
\text { Empreen- } \\
\text { dedorismo } \\
\text { Corporativo }\end{array}$ & $\begin{array}{l}35 \\
\text { anos }\end{array}$ & $\begin{array}{l}\text { Publicidade } \\
\text { (graduação) } \\
\text { MBA }\end{array}$ & $\begin{array}{l}2 \\
\text { anos }\end{array}$ & $\begin{array}{l}\text { Brasi- } \\
\text { leira }\end{array}$ & $\begin{array}{l}\mathrm{R} \$ 39 \text { bilhões } \\
\text { Presente em } \\
\text { mais de } 150 \\
\text { países }\end{array}$ & $\begin{array}{l}\text { Consumo } \\
\text { não } \\
\text { cíclico }\end{array}$ & $\begin{array}{l}\text { Inovadores } \\
\text { conser- } \\
\text { vadores }\end{array}$ \\
\hline 9 & $\begin{array}{l}\text { Gerente } \\
\text { Sênior de } \\
\text { Inovação }\end{array}$ & $\begin{array}{l}40 \\
\text { anos }\end{array}$ & $\begin{array}{l}\text { Administração } \\
\text { (graduação) } \\
\text { Pós-graduação e } \\
\text { MBA }\end{array}$ & $\begin{array}{l}10 \\
\text { anos }\end{array}$ & Asiática & $\begin{array}{l}\text { US\$ } 177 \\
\text { bilhões } \\
\text { Presente em } \\
\text { mais de } 80 \\
\text { países }\end{array}$ & $\begin{array}{l}\text { Consumo } \\
\text { cíclico }\end{array}$ & $\begin{array}{l}\text { Inovadores } \\
\text { conser- } \\
\text { vadores }\end{array}$ \\
\hline
\end{tabular}




\begin{tabular}{|c|c|c|c|c|c|c|c|c|}
\hline \multirow{2}{*}{ } & \multicolumn{4}{|c|}{$\begin{array}{c}\text { Características dos Especialistas } \\
\text { Entrevistados }\end{array}$} & \multicolumn{4}{|c|}{$\begin{array}{c}\text { Características das Empresas Multinacionais } \\
\text { onde trabalham }\end{array}$} \\
\hline & שึ & 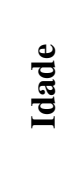 & : & 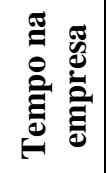 & 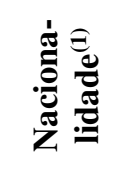 & 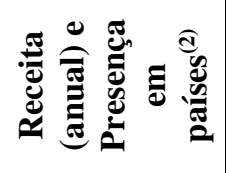 & 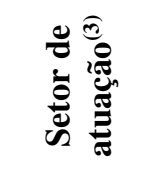 & 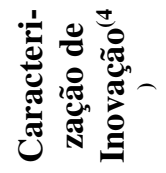 \\
\hline 10 & $\begin{array}{l}\text { Gerente } \\
\text { Sênior de } \\
\text { Marketing } \\
\end{array}$ & $\begin{array}{l}34 \\
\text { anos }\end{array}$ & $\begin{array}{l}\text { Administração } \\
\text { (graduação) }\end{array}$ & $\begin{array}{l}3 \\
\text { anos }\end{array}$ & \multirow[t]{2}{*}{$\begin{array}{l}\text { Norte- } \\
\text { ameri- } \\
\text { cana }\end{array}$} & \multirow{2}{*}{$\begin{array}{l}\text { US\$ } 15 \\
\text { bilhões } \\
\text { Presente em } \\
\text { mais de } 60 \\
\text { países }\end{array}$} & \multirow[t]{2}{*}{$\begin{array}{l}\text { Consumo } \\
\text { cíclico }\end{array}$} & \multirow[t]{2}{*}{$\begin{array}{l}\text { Inovadores } \\
\text { eficientes }\end{array}$} \\
\hline 11 & $\begin{array}{l}\text { Líder de } \\
\text { Projetos de } \\
\text { Inovação }\end{array}$ & $\begin{array}{l}37 \\
\text { anos }\end{array}$ & $\begin{array}{l}\text { Engenheira } \\
\text { Elétrica } \\
\text { (graduação) } \\
\text { Doutorado }\end{array}$ & $\begin{array}{l}6 \\
\text { anos }\end{array}$ & & & & \\
\hline 12 & $\begin{array}{l}\text { Vice- } \\
\text { Presidente }\end{array}$ & $\begin{array}{l}44 \\
\text { anos }\end{array}$ & $\begin{array}{l}\text { Administração } \\
\text { (graduação) } \\
\text { MBA e } \\
\text { Mestrado }\end{array}$ & $\begin{array}{l}11 \\
\text { anos }\end{array}$ & $\begin{array}{l}\text { Euro- } \\
\text { peia }\end{array}$ & $\begin{array}{l}\text { US\$ } 14 \\
\text { bilhões } \\
\text { Presente em } \\
\text { mais de } 100 \\
\text { países }\end{array}$ & Saúde & $\begin{array}{l}\text { Inovadores } \\
\text { de alta } \\
\text { intensidade }\end{array}$ \\
\hline $\begin{array}{l}\text { (2) } \\
\text { (3) } \\
\text { (4) }\end{array}$ & \&FBOVES & o $s i$ & $\begin{array}{l}\text { e cada organiz } \\
\text { órios anuais d }\end{array}$ & $16 \mathrm{~d}$ & 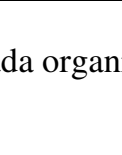 & ção. & & \\
\hline
\end{tabular}

Fonte: Quadro elaborado pela autora, com base em diversas fontes (2017).

\subsection{COLETA E ANÁLISE DOS DADOS}

A coleta de dados teve início em novembro de 2016, quando foram agendadas entrevistas com os funcionários das empresas elencadas no Quadro 7. Após quatro meses de contatos constantes, conseguiu-se entrevistar 7 (sete) funcionários de 5 (cinco) empresas. Em março de 2017, iniciou-se o contato com outras empresas, que não as selecionadas a priori, totalizando uma amostra composta por 12 (doze) entrevistados que atuam em nível de coordenação e liderança, em 9 (nove) organizações, como mencionado.

As entrevistas foram realizadas de diversas formas: presencial, por telefone, por Voice over Internet Protocol, Voz sobre IP (VoIP), Skype ou Google Hangouts e, a duração variou entre 40 e 60 minutos. Todos os áudios gravados foram transcritos com consentimento verbal dos entrevistados. Após a transcrição, todas entrevistas foram analisadas individualmente, destacando-se os principais pontos de cada um dos blocos de perguntas estipulados pelo roteiro inicial, buscando identificar semelhanças e diferenças simultaneamente para que fosse possível agrupar as empresas pelas respostas semelhantes (BAUER; GASKELL, 2002). Importante ressaltar que as falas dos entrevistados foram fielmente respeitadas, optando-se por manter, 
inclusive, eventuais repetições de palavras ou mesmo simples erros gramaticas, típicos da linguagem oral.

A análise das entrevistas foi realizada em função do tópico, conforme determina a matriz de amarração metodológica descrita no Quadro 2. Esses tópicos, por sua vez, são base do referencial teórico abordado e direcionaram os temas da análise, assim como a interpretação dos dados, conforme procedimento proposto por Bauer e Gaskell (2002). Para cada tópico, foram destacadas palavras que definiam a percepção do entrevistado para a questão abordada e/ou trechos da entrevista que ilustravam a questão.

A Figura 20 ilustra o processo empreendido na análise: primeiramente foi feita uma análise individualizada das entrevistas e, em seguida, uma análise conjunta de todas as entrevistas a fim de identificar semelhanças e diferenças nas definições e abordagens por parte dos especialistas.

Figura 20 - Análise das entrevistas
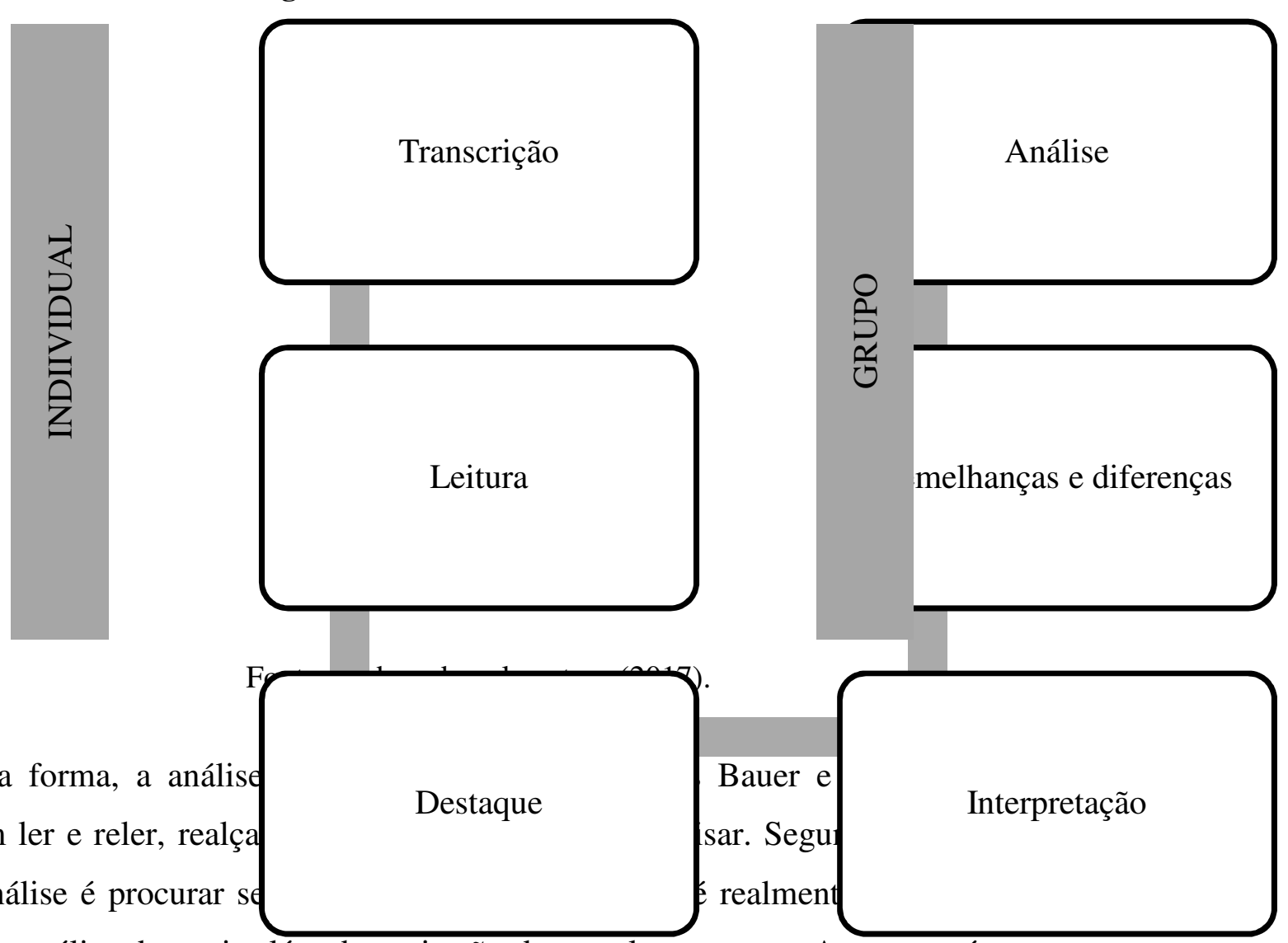

dados, mas a análise deve vir além da aceitação deste valor presente. A procura é por temas com conteúdo comum e pelas funções desses temas” (BAUER; GASKELL, 2002, p. 85). 


\section{ANÁLISE E INTERPRETRAÇÃO DOS RESULTADOS}

Neste capítulo, os resultados obtidos são expostos, discutidos e interpretados relacionando-os com o referencial teórico. Optou-se por apresentar os resultados na mesma sequência em que foram realizados os blocos de perguntas do roteiro pré-estabelecido, assim subdivididos:

- Inovação e modelos de negócio: definições dos temas do estudo e seu paralelo com a teoria;

- Estratégia e inovação: como as empresas estão estruturadas para inovar e desenvolver modelos de negócios;

- Tipos de inovação: foco de inovação nas empresas;

- Motivações, barreiras e papel da liderança: o que promove e o que inibe a inovação e o desenvolvimento de modelos de negócios.

Importante destacar que, apesar de, no roteiro de entrevistas, o bloco "Tipos de Inovação" estar após o bloco "Inovação e Modelos de Negócios", visando à melhor fluidez das entrevistas, para efeito de análise essa sequência foi alterada, passando então a ser primeiramente o bloco "Inovação e modelos de negócios", a seguir "Estratégia e inovação" e, então, “Tipos de Inovação”. Acredita-se que, do ponto de vista teórico, essa sequência tenha ficado mais lógica e interessante.

\subsection{CONCEITO DE INOVAÇÃO E MODELOS DE NEGÓCIOS}

De maneira geral, os entrevistados compartilham da mesma visão sobre inovação e a compreendem como sendo algo novo, que traz diferenciação, com grande destaque para a importância de gerar resultados. Um dos entrevistados afirma:

(...) inovação é uma junção de uma visão de negócios, que passa por entendimentos manifestados nos direitos do consumidor. Com uma invenção, então, você pega mil exemplos de visão de negócios que não trouxeram uma invenção bacana, seja porque tecnologicamente não fazia sentido, ou porque 
não endereçada essa visão, ou o contrário, uma invenção superbacana, mas que não fazia nenhum sentido, porque na época não respondia a nenhuma necessidade. O perfeito é quando você tem essa combinação. Então, é isso para mim, é uma junção de uma visão de negócio com um desenvolvimento de serviço que responda perfeitamente àquela visão [Entrevistado 9].

Na opinião de outro entrevistado,

(...) existe uma preocupação muito grande com a inovação, de ela realmente trazer resultados, ou seja, de ela aproveitar as oportunidades, de ela atender às necessidades, de ela fazer dinheiro... Então, eu diria para você, que não muda, é um processo estruturado, organizado, amplamente discutido, focado em colocar um produto no mercado e que traga dinheiro, que atenda às necessidades, oportunidades, e que traga dinheiro. O que pode mudar é esse dinamismo, a priorização, a repriorização [Entrevistado 2].

No Quadro 9, apresenta-se a prática versus a teoria, a partir do alinhamento das percepções dos entrevistados com as ideias principais de diversos autores e com os conceitos de inovação de Drucker (2002) e da OCDE (1997) e com a ausência de conceito de Von Hippel (2005).

Quadro 9 - Prática versus teoria: conceito de inovação

\begin{tabular}{|l|l|l|l|}
\hline Inovação & \multicolumn{1}{|c|}{ Autores } & \multicolumn{1}{|c|}{ Ideia principal } & \multicolumn{1}{|c|}{ Entrevistados } \\
\hline \multirow{4}{*}{ Conceito } & Drucker (2002) & $\begin{array}{l}\text { Exploração com sucesso de novas } \\
\text { ideias. }\end{array}$ & $1,2,3,4,5,6,7,8,9,12$. \\
\cline { 2 - 4 } & Drucker (2011) & Criação de um negócio ou serviço. & $3,10,11,12$. \\
\cline { 2 - 4 } & Schumpeter (1997) & $\begin{array}{l}\text { Criação de novos mercados; } \\
\text { empreendedorismo. }\end{array}$ & $7,8,11$. \\
\cline { 2 - 5 } & Chesbrough (2003b) & Inovação aberta e fechada. & $4,7$. \\
\cline { 2 - 5 } & OCDE (1997) & $\begin{array}{l}\text { Produto, processo ou método } \\
\text { novo ou melhorado. }\end{array}$ & $1,2,3,4,6,10,11,12$. \\
\cline { 2 - 5 } & Von Hippel (2005) & $\begin{array}{l}\text { Soluções desenvolvidas por lead } \\
\text { users. }\end{array}$ & N/A \\
\hline
\end{tabular}

Fonte: Quadro elaborado pela autora, com base em diversos autores e nos relatos dos entrevistados (2017).

A maioria dos especialistas entrevistados - dez dentre os doze - está engajada com a gestão de inovação de forma estruturada há mais de cinco anos. No entanto, o engajamento com modelos de negócios é mais recente, apenas três respondentes atuam de forma estruturada há mais de 10 anos. O Quadro 10 apresenta o número de especialistas engajados com inovação e com modelos de negócios em função do tempo. 
Quadro 10 - Número de especialistas engajados com inovação e com os modelos de negócios, em função do tempo

\begin{tabular}{|c|c|c|}
\hline Tempo de engajamento & Inovação & Modelos de Negócios \\
\hline Menos de 5 anos & 2 & 7 \\
\hline Entre 5 a 9 anos & 6 & 2 \\
\hline Acima de 10 anos & 4 & 3 \\
\hline
\end{tabular}

Fonte: Quadro elaborado pela autora (2017) com base nas entrevistas.

Segundo os especialistas entrevistados, o engajamento estruturado com a prática de inovação é evidenciado por ter:

- $\quad$ Processos formalizados, como um dos entrevistados relata:

(...) considerando todo o processo que a gente fez em direção de estruturar uma gestão mais estratégica da inovação, um processo e a partir desse processo desenvolveram-se tantos novos negócios quanto novas oportunidades para os negócios existentes [Entrevistado 6];

- Cultura de inovação. Um dos respondentes relata: “(...) se ele quiser ser um empreendedor agora, se ele quer inovar, na verdade, se ele quer inovar por ele mesmo, ele vai conversar com alguns dos portfólios que nós temos e vai submeter ao empreendedorismo" [Entrevistado 4];

- $\quad$ Engajamento de diversas áreas. Um dos entrevistados afirma: “(...) a inovação permeia várias áreas da empresa, é mais uma cultura da empresa" [Entrevistado 12];

- Metas estabelecidas. Um dos entrevistados relata:

(...) todo o ano a gente tem uma meta de ter novos produtos lançados no mercado, e a gente tem uma meta interna, que é um indicador legal, que chama vitality index onde o percentual $\mathrm{X}$ da nossa receita tem que advir de novos produtos ou novos negócios também. Então, isso é bacana porque mantém a empresa sempre focada nessas inovações, e a gente é medido e ganha remuneração variável por esse index também [Entrevistado 3].

No entanto, o envolvimento das organizações pesquisadas com os modelos de negócios é mais recente e menos estruturado, como destacaram alguns dos entrevistados. Na opinião de 
um deles, “(...) modelo de negócio já é algo um pouco mais (...), de menor porte em relação ao negócio em produto” [Entrevistado 2]. Outro entrevistado afirma: “(...)acho que existe a importância do tema inovação, superforte. Mas, pelo menos nos fóruns que participo, não vejo grandes discussões sobre modelo de negócio" [Entrevistado 5]. Outro entrevistado explica:

(...) vamos dizer, repensar em modelo de negócio. A gente sabe fazer, por enquanto a gente não entrou, porque, como eu falei, existe um delay ainda. Resolver alguma coisa global para ver o que de repente faz sentido a gente estudar e encomendar eventuais mudanças de modelo aqui e na região [Entrevistado 9].

Apesar de estarem engajadas em modelo de negócios há pouco tempo, há certo alinhamento dessas empresas com as teorias de Timmers (1998), como fonte de receita por meio de serviços. Um dos entrevistados afirma: "para mim, o desenvolvimento de modelo de negócios é sempre estar de olho em como a gente pode gerar novas fontes de receita no futuro, trabalhando com serviços" [Entrevistado 3].

Nos relatos de alguns entrevistados percebe-se uma aproximação com a visão de cadeia de valor de Adner (2006), ao relacionarem os diferentes atores que a compõem (consumidores, outras empresas) e ao integrarem diferentes processos. Segundo um dos entrevistados, "modelo de negócio, na minha opinião, é aquilo que faz a intermediação entre o ponto de vista do consumidor e o ponto de vista das empresas" [Entrevistado 2]. Outro entrevistado relata:

Nós temos um modelo na forma do financiamento do desenvolvimento de produto. Nós temos um modelo que chama modelo de parceria de risco. Então, modelo de parceria de risco, como funciona: o fornecedor entra como parceiro do nosso desenvolvimento; ele entra com dinheiro, com investimento, e ele é remunerado de forma diferente do que era antigamente, tem uma remuneração diferente com ele. Então, isso nos trouxe uma mudança no modelo e trouxe o codesenvolvimento real. Então, a gente de fato, desenvolve em conjunto com eles, exatamente porque eles são também donos do programa, vamos dizer assim [Entrevistado 4].

Um dos entrevistados explica: "modelo de negócio é como você encaixa diferentes processos ou diferentes modos de operar para atender uma demanda, como você combina um produto, uma ferramenta ou um serviço para poder atender uma demanda" [Entrevistado 11].

Pelos relatos dos entrevistados pode-se estabelecer uma aproximação como desdobramento da estratégia empresarial de Seddon e Lewis (2003). Um deles relata: "modelo de negócio, para mim, tem a ver com a forma de atuação de determinada empresa" [Entrevistado $5]$.

Segundo o que foi destacado pelos entrevistados, pode-se constatar que há também uma aproximação com Osterwalder (2004) e Johnson, Christensen e Kagermann (2008), na 
abordagem da relação com os clientes e parceiros e na remuneração recebida pela empresa ao entregar valor para o mercado. Segundo um dos entrevistados, "modelo de negócio para mim é a maneira como uma empresa faz dinheiro, como uma empresa atende seus clientes, e como é remunerada pelos seus clientes a partir daquilo que ela oferece" [Entrevistado 4]. Na opinião de um deles:

(...) você tem que pensar não só na parte fragmentada do produto em si, tem o seu valor, mas todos os stakeholders, todos os agentes. Ali, entendo que é isso aí, desenhar essa interação entre os vários componentes, de como você ganha o seu dinheiro, o valor que você entrega, os seus parceiros, seus canais, e que isso coloca a solução de pé [Entrevistado 7].

O Quadro 11 relaciona a ideia principal do conceito de modelos de negócios, segundo revisão teórica abordada e a definição obtida pelos entrevistados. É notável o alinhamento de modelo de negócios com o conceito de Osterwalder (2004), por meio da entrega de valor para os clientes, e com o de Adner (2006), alinhado com a integração da cadeia de valor. A definição estabelecida por Casadesus-Masanell e Ricart (2010) não foi identificada nos relatos dos entrevistados.

Quadro 11 - Prática versus teoria: conceito de modelos de negócios

\begin{tabular}{|l|l|l|l|}
\hline $\begin{array}{c}\text { Modelos de } \\
\text { Negócios }\end{array}$ & \multicolumn{1}{|c|}{ Autores } & \multicolumn{1}{|c|}{ Ideia Principal } & \multicolumn{1}{c|}{$\begin{array}{c}\text { Entre- } \\
\text { vistados }\end{array}$} \\
\hline \multirow{5}{*}{ Conceito } & Seddon; Lewis (2003) & Abstração da estratégia de uma empresa. & 5. \\
\cline { 2 - 5 } & $\begin{array}{l}\text { Casadesus-Masanell; } \\
\text { Ricart (2010) }\end{array}$ & $\begin{array}{l}\text { Reflexo da estratégia realizada pela } \\
\text { empresa. }\end{array}$ & N/A. \\
\cline { 2 - 5 } & Osterwalder (2004) & $\begin{array}{l}\text { A Visão da empresa e sua estratégia são } \\
\text { traduzidas em propostas de valor, relações } \\
\text { com clientes e redes de valor. }\end{array}$ & $1,3,7,6,9$, \\
\cline { 2 - 5 } & Timmers (1998) & Fontes de receitas. & $3,10$. \\
\cline { 2 - 5 } & Adner (2006) & Cadeia de valor e integração. & $2,4,8,11$. \\
\hline
\end{tabular}

Fonte: Quadro elaborado pela autora, com base em diversos autores e nos relatos dos entrevistados (2017).

A importância de inovação para as empresas está alinhada com a necessidade de sobrevivência em um ambiente competitivo (PORTER, 1999) e com a necessidade de rever sua estratégia a longo prazo (CASADESUS-MASANELL; RICART, 2010). Na opinião de um dos entrevistados:

(...) se as grandes empresas continuarem focando somente no core business, num prazo de alguns anos vão acabar ficando para trás, porque os outros concorrentes vão fazer outras coisas. Os entrantes no mercado vão ter produtos com performance tão boa quanto os grandes fabricantes têm hoje em dia. 
Então, é crucial que a própria [empresa] evolua os seus modelos de entrega por mercado [Entrevistado 10].

Conforme destacado na revisão teórica, as empresas adotam estratégias radicais quando mudanças no seu ambiente tornam o negócio atual obsoleto, como exemplifica um dos entrevistados, cuja empresa criou um novo produto que compete com o seu core business. Segundo ele:

(...) a gente criou um produto que compete com nós mesmos, e não é toda a empresa que faz isso, que reconhece dizendo: - isso aqui eu tenho como fazer melhor e vou fazer sim (...). Tem empresa que tem muito receio de fazer isso, de criar produtos que possam concorrer com os seus próprios [Entrevistado $1]$.

Ou quando, voluntariamente, a empresa decide desenvolver um modelo de negócios. Unir inovação e modelo de negócios potencializam os resultados. Na opinião de um dos entrevistados:

(...) quando você olha inovação e produto só no pilar produto, você, na verdade, está usando só parte do potencial. Os grandes shifts, com certeza, eles vão trazer uma mudança no modelo de negócio porque eles vão usar as outras dimensões(...). Quando você vai aproveitar algo novo, se você usa todas as alavancas, todas as dimensões do modelo de negócio, você consegue um resultado potencialmente muito maior, tanto do ponto de vista de vantagem competitiva, e do ponto de vista de retorno econômico-financeiro [Entrevistado 6].

O entendimento e o conhecimento por parte dos entrevistados quanto aos dois temas do estudo - inovação e modelo de negócios - estão alinhados entre as empresas pesquisadas, bem como em relação às teorias de Casadesus-Masanell e Ricart (2010). O tema de inovação também está alinhado com as ideias de Drucker (2002), Porter (1999), Schumpeter (1997). Os modelos de negócios, por sua vez, estão alinhados com as teorias de Adner (2006), Osterwalder (2004), Johnson, Christensen e Kagermann (2008), Seddon e Lewis (2003) e Timmers (1998), com destaque para a importância econômico-financeira para ambos os temas, sendo inovação como busca de competitividade e modelos de negócios como fonte de geração de valor e remuneração para as empresas. 


\subsection{PROCESSO DE INOVAÇÃO E DESENVOLVIMENTO DE MODELO DE NEGÓCIO}

Um dos objetivos propostos para o presente estudo foi descrever como especialistas que trabalham em grandes empresas fazem a gestão de inovação de forma estratégica e como esta última se relaciona com o desenvolvimento de modelos de negócios. Tendo isto em mente, neste subcapítulo discute-se a forma como as empresas estão estruturadas para inovar e desenvolver modelos de negócios em busca de competitividade, a partir das menções dos respondentes.

Via de regra, a inovação faz parte da estratégia das empresas dos especialistas pesquisados, como, inclusive, afirma um dos entrevistados:

(...) inovação e tecnologia sim, faz parte da estratégia, a gente tem esforços distintos para os distintos negócios. Quero dizer o seguinte: tem negócios que são mais maduros; as tecnologias são mais maduras, são disponíveis. Então, nosso esforço é em uma direção, na direção mais de ser capaz de fazer as boas escolhas, ter boas pessoas para fazer uma boa avaliação, para que eu consiga um aprimoramento tecnológico na melhor hora (...). Quando a gente vai para outro negócio, essa combinação já não é possível, e as tecnologias não são tão disponíveis. Então, tenho um outro desafio, tenho um desafio de ter que ir desenvolvendo do ponto de vista tecnológico soluções exclusivamente (...). Agente trabalha a estratégia numa visão de negócio, então, os negócios têm as suas estratégias, aí a gente tem uma estratégia tecnológica para cada um dos negócios, e isso converge para uma estratégia da companhia [Entrevistado 1].

Contudo, a estratégia de modelos de negócios está implícita como sendo parte do negócio da empresa (SEDDON; LEWIS, 2003), o que é comprovado pelas afirmações de alguns entrevistados: “(...) temos os objetivos estratégicos para diversificar os nossos negócios, isso na prática significa inovar modelos de negócio" [Entrevistado 4]. “(...) o CEO atual tem seis estratégias, uma delas, a terceira, está escrito lá que é inovação, isso já está no modelo de negócios, no modus operandi" [Entrevistado 7].

Do ponto de vista de desenvolvimento da inovação, os gestores respondentes esclarecem que as empresas estão bem estruturadas, seguindo o processo definido por Tidd, Bessant e Pavitt (2008). Alguns entrevistados mencionam que a empresa adota a metodologia de Stage-gates, de Cooper (1994), de aprovação para passar para a próxima etapa. Segundo um deles, “(...) especificamente para inovação, existe um modelo de Stage-gate que começa desde a busca pela oportunidade, pelas demandas do mercado" [Entrevistado 11]. Outro afirma:

(...) tem toda uma metodologia: os primeiros passos normalmente são estes de ter um banco de ideia, um banco de oportunidades; depois a gente faz um segundo passo de análise dessas oportunidades para tentar mensurar potencial, mensurar o tamanho dessas oportunidades. Cada etapa dessa tem um Stage- 
gate (...) você pode, a cada etapa dessa, continuar ou matar aquele projeto de inovação, de acordo com os resultados [obtidos]. Então, é bem estruturado dessa maneira [Entrevistado3].

Além da metodologia de Cooper (1994), a gestão da inovação é alinhada com o modelo Temaguide (COTEC, 1998), como mencionado por um dos entrevistados:

(...) a gente também tem tentado, buscado ajustar os processos a essas dinâmicas, a essas velocidades, sem desrespeitar a disciplina que a gente já tem, os indicadores, que são comuns para as diferentes regiões. A gente consegue dar uma visão para os líderes de quanto a gente tá gastando, quanto a gente tá imaginando entregar por ano, por área, e também mantendo o track record disso, o que a gente aprendeu e o que não aprendeu, a documentação dos projetos, seja pro nosso aprendizado. Tem coisas aí que até a ISO a gente tem que atender, então, toda essa parte documental é respeitada [Entrevistado $1]$.

Essa estruturação acarreta em busca de oportunidades para negócios existentes e até mesmo para novos negócios, como destacado por um dos entrevistados:

(...) considerando todo o processo que a gente fez em direção de estruturar uma gestão mais estratégica da inovação, e a partir desse processo desenvolveram-se tantos novos negócios quanto novas oportunidades para os negócios existentes [Entrevistado 6].

No Quadro 12 está relacionado o processo de inovação adotado pelas empresas, segundo informações obtidas com os próprios entrevistados, com grande destaque para a metodologia de Stage-Gates, de Cooper (1994). Nota-se a ausência para a implementação de processo de inovação, segundo Birkinshaw e Hamel (2008) e Veryzer (1998).

Quadro 12 - Prática versus teoria: processo de inovação

\begin{tabular}{|c|c|c|c|}
\hline Inovação & Autores & Ideia principal & Entrevistado \\
\hline \multirow{5}{*}{ Processos } & Cooper (1994) & Stage-Gates. & $2,3,5,6,7,8,9,10,11$ \\
\hline & COTEC (1998) & Modelo Temaguide. & $1,4,12$ \\
\hline & $\begin{array}{l}\text { Birkinshaw e Hamel } \\
\text { (2008) }\end{array}$ & $\begin{array}{l}\text { Agentes internos e externos, } \\
\text { contexto organizacional e } \\
\text { contexto ambiental. }\end{array}$ & N/A. \\
\hline & $\begin{array}{l}\text { Tidd; Bessant: } \\
\text { Pavitt(2008) }\end{array}$ & $\begin{array}{l}\text { Busca de oportunidades, escolha e } \\
\text { desenvolvimento. }\end{array}$ & 9. \\
\hline & Veryzer (1998) & Protótipos e lead users. & N/A. \\
\hline
\end{tabular}

Fonte: Quadro elaborado pela autora, com base em diversos autores e nos relatos dos entrevistados (2017).

Sob a ótica do desenvolvimento de modelo de negócios, a maioria das empresas não está estruturada exclusivamente para isso, conforme destacam alguns entrevistados. Segundo 
um deles, "não existe um processo formalizado de desenvolvimento, mas é muito parecido com esse que eu expliquei, só não é uma metodologia oficial e confirmada, até pelo fato de ser incipiente" [Entrevistado 3]. Outro afirma:

Não [estamos estruturados], o que a gente trouxe foi uma robustez muito maior nesses últimos tempos (...). Qual o modelo de negócio? Vou fazer uma parceria com sei lá quem? Vou ter que vender diferente, vou parar de vender via distribuição? Isso é, não deixa de ser uma abordagem de modelo de negócio [Entrevistado 7].

Ao opinar sobre a empresa na qual trabalha, um dos entrevistados afirma: "produto eu vou dizer que tem, modelo de negócios não tem" [Entrevistado 8]. Outro entrevistado relata: "não existe um processo para isso, creio que isso emerge naturalmente. À medida que a empresa desenvolve um produto, ou identifica um novo parceiro, a empresa trata de moldar este modelo de negócio, mas não existe um processo formal para isso" [Entrevistado 12].

No entanto, existem iniciativas recentes, como mencionado por um dos entrevistados, que buscam a formalização do processo exclusivo para o desenvolvimento de novos negócios. Segundo ele, “(...) existe um processo, que a gente implantou recentemente, tem uns 5 ou 6 meses. Não é muito diferente do processo de inovação, vamos chamar de processo de inovação" [Entrevistado 4].

Porém, a separação entre inovação e modelo de negócios é complexa, dado ao alinhamento de ambos à estratégia da organização envolvida no processo (SEDDON; LEWIS, 2003; CASADESUS-MASANELL; RICART, 2010). Para alguns respondentes, desenvolver inovações é desenvolver modelos de negócios, pois sem a adoção de ambos a indústria perde valor.

(...) se a indústria não prover novas soluções (...) ela perde sua importância, inclusive (...). A indústria tem que prover novas soluções. Em relação a modelos de negócio, a indústria ela trabalha com várias frentes de produtos, então, cada uma delas tem um modelo de negócio, por exemplo, tem modelos onde o cliente principal é uma fonte pagadora, modelos de negócio onde o cliente principal é o usuário do produto (...). Então, a empresa sempre decide por criar o seu modelo de negócio, de acordo com o usuário, com o cliente final [Entrevistado 12].

Pode-se dizer que os especialistas entrevistados abordam inovação de forma estratégica nas empresas em que trabalham, ou seja, alinhada com os objetivos de crescimento de longo prazo. Um dos entrevistados explica: “(...) toda a estratégia de longo prazo conta com o desenvolvimento de novos negócios ou receita advindas de inovação" [Entrevistado 3]. Em alguns casos, a inovação faz parte da agenda de discussão das empresas, como afirma outro 
entrevistado: “(...) existe a importância do tema inovação, superforte, pelo menos nos fóruns que participo" [Entrevistado 5].

Em outras situações, especialistas de algumas empresas visam a resultados financeiros. No ponto de vista de um dos entrevistados, “(...) enxergam a entrega da área de inovação como um compromisso que o vice-presidente tem que entregar um certo volume de lucro líquido no final de um período de tempo" [Entrevistado 11].

O Quadro 13 relaciona a ideia principal de desenvolvimento de modelo de negócios, segundo a revisão teórica discutida e a abordagem das empresas, no ponto de vista dos entrevistados. Em dois casos, pode-se identificar um desenvolvimento próximo às teorias de Johnson, Christensen e Kagermann (2008) e às de Osterwalder (2004), por meio da abordagem de parte dos componentes de modelo de negócios.

Quadro 13 - Prática versus teoria: desenvolvimento de modelo de negócios

\begin{tabular}{|c|c|c|c|}
\hline $\begin{array}{l}\text { Modelo de } \\
\text { Negócios }\end{array}$ & Autores & Ideia Principal & Entrevistados \\
\hline \multirow{6}{*}{ Desenvolvimento } & $\begin{array}{l}\text { Johnson e } \\
\text { colaboradores } \\
\text { (2008) }\end{array}$ & $\begin{array}{l}\text { Proposta de valor, fórmula de lucro, } \\
\text { recursos e processos chaves. }\end{array}$ & 4 e 7 \\
\hline & $\begin{array}{l}\text { Osterwalder } \\
(2004)\end{array}$ & $\begin{array}{l}\text { Produtos, interface do cliente, } \\
\text { gestão de infraestrutura e aspectos } \\
\text { financeiros. }\end{array}$ & 4 e 7 \\
\hline & $\begin{array}{l}\text { Osterwalder e } \\
\text { Pigneur (2010) }\end{array}$ & $\begin{array}{l}\text { Oferta (oferta e valor), cliente } \\
\text { (segmentos de clientes, } \\
\text { relacionamento e canais), } \\
\text { infraestrutura (parceiros-chaves, } \\
\text { atividades-chaves e recursos- } \\
\text { chaves) e finanças (fontes de } \\
\text { receitas e estrutura de custos). }\end{array}$ & 4 e 7. \\
\hline & Porter (1999) & Líder em custo ou diferenciação. & $1,5,6,10,12$ \\
\hline & Timmers (1998) & Grau de inovação ou integração. & 3,8 \\
\hline & $\begin{array}{l}\text { Frankenberger e } \\
\text { colaboradores } \\
\text { (2013) }\end{array}$ & $\begin{array}{l}\text { Abordagem dos 4I's (iniciação, } \\
\text { ideação, integração e } \\
\text { implementação). }\end{array}$ & N/A \\
\hline
\end{tabular}

Fonte: Quadro elaborado pela autora, com base em diversos autores e nos relatos dos entrevistados (2017).

Na opinião de um dos entrevistados, "interação entre os vários componentes, de como você ganha o seu dinheiro, o valor que você entrega, os seus parceiros, seus canais" [Entrevistado 7]. Para a maioria das empresas, segundo a abordagem de Porter (1999), líder em custo ou diferenciação é o que dita o desenvolvimento de modelo de negócios. Em duas empresas pode-se notar uma aproximação com a teoria de Timmers (1998), seja pelo grau de inovação ao externalizar atividades internas, uma vez que na opinião de um dos entrevistados, 
“a inovação de modelos de negócios digital é uma parceria para oferta de produtos sendo vendidos através do site da empresa" [Entrevistado 3], ou seja pelo grau de integração, pois "tá começando a mudar toda a nossa cadeia, é uma cadeia muito complexa, a gente tá começando devagar, tá sendo piloto" [Entrevistado 4]. Não obstante, a abordagem mais estruturada para modelo de negócios da forma como foi colocada por Frankenberger e colaboradores (2013) não foi mencionada pelos entrevistados.

\subsection{TIPOS DE INOVAÇÃO}

Mapear o foco de inovação nas empresas dos respondentes para compreender qual a relação com o desenvolvimento de modelo de negócios foi outro objetivo do presente estudo. Para tanto, questionou-se com os entrevistados quais os tipos de inovação desenvolvidos nas empresas e como cada um deles contribui para a competitividade. Não obstante, procurou-se entender quais inovações desenvolvem modelo de negócios para as empresas.

Os gestores entrevistados das multinacionais pesquisadas inovam de maneira estruturada há quase 10 anos. No entanto, desde 2010, a inovação voltada para modelo de negócios é diversa, seja em caráter experimental seja pelo direcionamento estratégico ou ainda pela estrutura de processo.

No que tange ao caráter experimental, um dos entrevistados relata:

(...) nós fizemos alguma experimentação de modelo novo de negócio no passado. Esse modelo de negócio funcionou por um período de 1 ano, 2 anos; ele nos trouxe algum aprendizado bastante interessante (...). Tem coisas que precisam ser mudadas, aprimoradas, então é uma experimentação que a gente fez por um período de tempo e que fica agora guardado para gente digerir, entender melhor os acertos, as melhorias que precisam ser feitas para a gente voltar no futuro a pensar a respeito [Entrevistado 2].

No que tange ao direcionamento estratégico, um dos entrevistados explica: “(...) acontecem nos países onde estão as prioridades, mas isso hoje é um grande plano global, não é mais algo de inovações regionais" [Entrevistado 6].

No que tange à estrutura de processo, um dos entrevistados relata:

(...) existe um processo implantado recentemente, tem uns 5 ou 6 meses, não é muito diferente do processo de inovação. Vamos chamar de processo de inovação. Esse é que é o ponto: o modelo de negócio faz parte da inovação, assim como a inovação faz parte do programa estratégico. Existe muita integração, não tem tanta separação, toda a vez que a gente faz uma inovação, existe a fase de modelo de negócio agora é a primeira fase [Entrevistado 4]. 
Em geral, na visão dos especialistas entrevistados, as empresas desenvolvem todos os tipos de inovação, como: produto, processo, incremental, radical e disruptiva, alinhados com as teorias de Christensen (2000), com as de Davila, Epstein e Shelton (2005) e com as da OCDE (1997). E, todos, de certa forma, contribuem para o aumento da competitividade, como mencionou um dos entrevistados: “(...) essa inovação é incremental do ponto de vista técnico, mas não incremental do ponto de vista financeiro" [Entrevistado 9].

O Quadro 14 relaciona os tipos de inovação desenvolvidos nas empresas, segundo relato dos entrevistados, alinhados com as ideais principais de alguns autores. Apenas dois respondentes mencionaram desenvolver inovações que podem ser classificadas como revolucionárias, sob a ótica de Abernathy e Clark (1985), adotam tecnologias não existentes devido, principalmente, ao seu setor de atuação (no caso, bens industriais e saúde).

Quadro 14 - Prática versus teoria: tipos de inovação

\begin{tabular}{|l|l|l|l|}
\hline Inovação & \multicolumn{1}{|c|}{ Autores } & \multicolumn{1}{c|}{ Ideia principal } & \multicolumn{1}{c|}{ Entrevistados } \\
\hline \multirow{5}{*}{ Tipos } & $\begin{array}{l}\text { Davila, Epstein e } \\
\text { Shelton (2005) }\end{array}$ & $\begin{array}{l}\text { Incremental, semi-radical e } \\
\text { radical. }\end{array}$ & $\begin{array}{l}1,2,3,4,5,6,7,8,9,10,11, \\
12 .\end{array}$ \\
\cline { 2 - 4 } & OCDE (1997) & $\begin{array}{l}\text { Produto, processo, marketing e } \\
\text { organizacional. }\end{array}$ & $\begin{array}{l}1,2,3,4,5,6,7,8,9,10,11, \\
12 .\end{array}$ \\
\cline { 2 - 4 } & Christensen (2000) & $\begin{array}{l}\text { Sustentação, de ruptura e de } \\
\text { modelo de negócios. }\end{array}$ & $2,3,4,5,6,7,12$. \\
\cline { 2 - 4 } & $\begin{array}{l}\text { Abernathy e Clark } \\
\text { (1985) }\end{array}$ & $\begin{array}{l}\text { Arquitetônica, nicho, regular e } \\
\text { revolucionária. }\end{array}$ & $4,12$. \\
\hline
\end{tabular}

Fonte: Quadro elaborado pela autora, com base em diversos autores e nos relatos dos entrevistados (2017).

No entanto, apenas as inovações radical e disruptiva geraram modelo de negócios nas empresas dos especialistas entrevistados, ou seja, a escolha do tipo de inovação impacta não apenas no cenário competitivo, como também no modelo de negócios estabelecido (CHESBROUGH, 2010).

O Quadro 15 ilustra os tipos de inovação desenvolvidos e como cada um contribuiu para a competitividade empresarial e/ou criou modelo de negócios. Importante destacar que o aumento da competitividade foi avaliado de forma qualitativa e espontânea pelos entrevistados, isto é, não foram questionados sobre o grau de melhoria dos indicadores financeiros em função de cada inovação. Não obstante, o desenvolvimento de modelo de negócios foi exemplificado pelos entrevistados, mas, para preservar a identidade das empresas, os negócios criados não podem ser divulgados. 
Quadro 15 - Tipos de inovação e relação entre competitividade e modelo de negócios nas empresas pesquisadas

\begin{tabular}{|l|c|c|c|}
\hline \multicolumn{1}{|c|}{ Tipos de Inovação } & $\begin{array}{c}\text { Desenvolvimento nas } \\
\text { empresas }\end{array}$ & $\begin{array}{c}\text { Aumento da } \\
\text { Competitividade }\end{array}$ & Modelo de Negócios \\
\hline Produto & $\mathrm{X}$ & $\mathrm{X}$ & \\
\hline Processo & $\mathrm{X}$ & $\mathrm{X}$ & \\
\hline Incremental & $\mathrm{X}$ & $\mathrm{X}$ & \\
\hline Radical & $\mathrm{X}$ & $\mathrm{X}$ & $\mathrm{X}$ \\
\hline Disruptiva & $\mathrm{X}$ & $\mathrm{X}$ & $\mathrm{X}$ \\
\hline
\end{tabular}

Fonte: Quadro elaborado pela autora (2017) com base nas entrevistas.

Porém, devido aos momentos cíclicos das empresas, há uma repriorização da abordagem sobre inovação, alinhada com os conceitos de Kelley (2011). Não obstante, o processo estruturado, organizado, voltado para a realização e repetição do sucesso não se altera (TIDD; BESSANT; PAVITT, 2008). Um dos entrevistados relata:

(...) à medida que você sai de uma crise para outra, muitas vezes as prioridades mudam e eu arrisco a dizer que o disruptivo acaba perdendo importância conforme o momento é mais incerto, e ganha muito mais relevância o incremental na modelagem. Mas, o processo em si, a cultura em si de inovação ela não muda [Entrevistado 2].

Vale destacar que, apesar de as empresas pesquisadas desenvolverem inovação aberta (CHESBROUGH, 2003b), ao envolverem fornecedores, consumidores e parceiros no processo de desenvolvimento de inovação e até mesmo de modelo de negócios, o tema não foi mencionado espontaneamente por nenhum dos entrevistados, seja no início do processo de desenvolvimento, por meio da captura de insights, seja no meio do processo para teste da inovação. Quando questionados, um dos respondentes explicou a limitação dos colaboradores para todo o processo:

(...) a gente não tem competência interna para fazer esse negócio. Hoje até a gente já aprendeu bastante, mas é sempre bom vir gente de fora. Tem umas duas empresas que a gente trabalha e são elas que modelam e coordenam, introduzem o assunto etc. [Entrevistado 7].

Por outro lado, o conceito de lead users (VON HIPPEL, 2005) não foi mencionado direta ou indiretamente por nenhum dos participantes da pesquisa. No entanto, dois respondentes possuem alguma iniciativa com a metodologia de design thinking, abordagem centrada no usuário e destinada a resolver problemas, auxiliando as organizações a serem mais inovadoras e criativas (BROWN, 2010). Um dos entrevistados relata: “(...) nos últimos quatro 
anos a corporação começou também a trazer um design thinking de uma forma, que lá nos Estados Unidos chama de outro nome, mas de qualquer forma é uma espécie de design thinking" [Entrevistado 7]. Porém, outro entrevistado indica que há limitação da matriz:

(...) a gente fazia pouco e projetos muito grandes. Demorava três meses, a gente fazia lá, tudo, diamante do design thinking, testando etc., conceitos que a gente achava incríveis, mas quando batiam, alguns não iam para a frente, a gente não sabia o porquê. Os caras fizeram análise mais avançada de custo e falaram que não valia a pena, mas agora a gente vai se permitir ir um pouco além [Entrevistado 9].

Importante ressaltar que o desenvolvimento de modelo de negócios pode estar pautado no desenvolvimento de novas tecnologias, ao empregar conhecimento voltado a atender uma necessidade de mercado. Segundo um dos entrevistados:

(...) em modelo de negócio, acho que a principal mudança é a de tecnologia (...) acho que os dois são modelos de negócios bastante diferentes do que se estava habituado, e, de fato, eles têm; mudou a dinâmica de forma de consumo, então, considero que mais de modelo de negócio do que de inovação de produto [Entrevistado 5].

Ou em uma nova forma de abordar o mercado ao criar um novo segmento democratizando uma tecnologia existente conforme menção de um dos entrevistados: “(...) a inovação disruptiva (...) do ponto de vista tecnológico não tinha muita novidade, mas criou o mercado global" [Entrevistado 4].

Do ponto de vista de inovações, as empresas, no geral, estão avançadas ao buscar o desenvolvimento em diferentes frentes - produto, processo, incremental, radical, disruptiva no entanto, apenas as duas últimas formas de inovações foram capazes de criar modelos de negócios distintos do core das empresas.

\subsection{MOTIVAÇÕES, BARREIRAS E PAPEL DA LIDERANCA}

O presente estudo também teve como objetivo entender o que promove e o que inibe a inovação voltada ao desenvolvimento de modelo de negócios. Sobre esse aspecto, os entrevistados discorreram sobre motivações, barreiras e papel da liderança.

As empresas tradicionais buscam reforçar sua presença (CHRISTENSEN, 2003a), porém encontram dificuldades para mudar o modelo de negócios já estabelecido (TEECE, 2010). Um dos entrevistados explica: “(...) as pessoas vão cada vez questionar mais o status quo e buscar competitividade. A inovação do modelo de negócio pode alavancar isso, por outro 
lado, a iniciativa precisa estar muito estruturada, fundamentada para poder sobreviver" [Entrevistado 8].

A busca por um diferencial está presente em grande parte dos gestores pesquisados, seja para se manterem em um ambiente competitivo (PORTER, 1999), seja para se manterem líderes, fazer diferente ou ampliar o segmento de atuação das empresas em que atuam. Um dos entrevistados explica: “o que move é o desafio (...) a gente está sempre olhando como a gente pode fazer melhor, como a gente pode ampliar a nossa abrangência, o portfólio dos nossos produtos" [Entrevistado 1]. Outro relata: "a nossa motivação é criar diferencial para se manter na liderança" [Entrevistado 3]. Um outro afirma:

O que nos move hoje, eu diria, num primeiro patamar é o nosso mote de competir (...). O objetivo, de verdade, é a gente fazer a diferença no mundo, e junto com a nossa competência; e claro que, com isso, a gente vai crescer bastante e gerar muitos empregos, satisfazer clientes e stakeholders e tudo o mais [Entrevistado 4].

Um dos entrevistados afirma ter "liderança em produto" [Entrevistado 6], outro constata "a necessidade de atender ao mercado de formas distintas, para continuar valorizando a empresa e respondendo aos acionistas, entregando uma empresa que tem perspectiva de crescimento" [Entrevistado 11].

As empresas buscam motivar os colaboradores a inovarem, seja por meio de “(...) modelo de avaliação e de reconhecimento através de participação com resultado" [Entrevistado 1] ou por meio de “(...) processo estimulado de melhoria contínua, que funciona através de um programa de sugestões" [Entrevistado 2].

Tendo como foco principalmente a área de Pesquisa e Desenvolvimento (P\&D), um dos entrevistados relata: “(...) tem um prêmio todo ano para os caras que depositam mais patentes, ou que dão mais ideias" [Entrevistado 6]. Ou quando estruturado para toda a organização, como explicam dois respondentes:

O Programa Inova tem três grandes atuações: tem uma atuação de cultura, que realizamos diagnóstico anual de cultura para entender como está a cultura de inovação, para ter certeza que nós não vamos perder. Tem um programa de reconhecimento, que reforça a cultura; e tem um programa de empreendedorismo interno, que qualquer pessoa pode submeter a inovação, a gente dá $20 \%$ numa fase, aí até $100 \%$ numa segunda fase, caso as pessoas tenham bastante sucesso, então, é um programa já de cinco anos, tem a estratégia bem madura [Entrevistado 4].

As pessoas são motivadas a trazerem ideias, a colaborarem com suas ideias, e aquelas ideias que são as vencedoras, a maioria delas são colocadas em prática e são reconhecidas (...) a empresa se preocupa em fazer com que seus 
funcionários sempre tragam novidades ou soluções para os problemas que a empresa enfrenta [Entrevistado 12].

Alinhadas com a teoria de Kuemmerle (2006), há barreiras comportamentais internas, como se pode constatar na explicação dos entrevistados: “(...) muitas vezes os caras são pegos no dia a dia, na pressão da semana" [Entrevistado 9], além de barreiras específicas de contexto: “(...) [há] limitação de recurso financeiro e de pessoas” [Entrevistado 5].

Ambas as barreiras influenciam na habilidade de grandes empresas em inovar, claramente destacada por um dos respondentes: “(...) a principal barreira que a gente tem hoje é o tamanho da empresa e o status quo do negócio como é hoje” [Entrevistado 3].

Uma grande empresa, como as que compuseram a amostra deste estudo, pode perder flexibilidade devido a conflitos com o negócio atual, ou pela configuração dos ativos que suportam o modelo existente (CHESBROUGH, 2010):

\begin{abstract}
(...) a primeira barreira é operacional. Então, o que eu quero dizer com isso, se eu ficar fazendo um monte de coisa nova, eu vou drenar recursos das coisas atuais, então, existe um princípio em termos de fazer coisas novas, mas a gente não pode matar a máquina para investir $100 \%$ em coisas novas. Então, eu diria que a primeira barreira, e talvez não seja uma barreira, seja um plano estratégico, é fazer numa intensidade que não prejudica o nosso core, o core de onde vem a maior parte do faturamento e a estrutura da empresa. Acho que isso está ligado no modelo de negócio na medida em que, por exemplo, é uma empresa mais tradicional [Entrevistado 6].
\end{abstract}

Não obstante, o desenho de um modelo de negócios para preparar a empresa para o futuro é uma tarefa difícil, pois necessita repensar o modelo anterior (ZOTT; AMIT, 2010). Assim, as pessoas exercem papel fundamental no processo (BIRKINSHAW; HAMEL, 2008) de criar a diferenciação por meio do desenvolvimento de modelo de negócios, como mencionado por um dos entrevistados: “(...) gente que viu oportunidade (...) pessoas empreendedoras do Brasil que se aventuraram nisso" [Entrevistado 7].

Esse mesmo entrevistado destaca também a importância de ter uma cultura inovadora para "romper o convencional" e permitir a abordagem "de querer fazer" [Entrevistado 7].

Alinhado com a proposição de Chesbrough (2010), o papel da liderança visa a “(...) reduzir as barreiras, influenciar as áreas que não conhecem a respeito daquele novo modelo de negócio, ou das oportunidades de que aquilo é algo que vale a pena" [Entrevistado 3].

Em geral, a cultura organizacional conta com “(...) crenças e propósitos” [Entrevistado 1]. Compartilhar o novo modelo é fundamental para que a mudança aconteça uma vez que a “(...) inovação permeia várias áreas da empresa, é mais uma cultura da empresa” [Entrevistado $12]$. 
Assim, como a atuação da liderança condiciona e influencia o sistema de inovação muito mais do que a origem do capital e o setor de atuação das organizações (STEFANOVITZ, 2011), é de suma importância que os líderes das grandes empresas estejam predispostos a inovar, tanto para motivar os colaboradores, quanto para superar barreiras existentes para que modelo de negócios sejam criados. 


\section{CONSIDERAÇÕES FINAIS}

Com base no estudo realizado, que teve como metodologia a realização de pesquisa exploratória qualitativa, apresenta-se, a seguir, a síntese dos resultados com as principais contribuições, as limitações dos resultados obtidos e as recomendações para eventuais estudos futuros no campo do desenvolvimento de modelo de negócios por meio da inovação em grandes organizações.

\subsection{SÍNTESE DOS RESULTADOS}

O presente estudo estabeleceu como problema de pesquisa delinear "como a inovação por meio do desenvolvimento de modelo de negócios contribui para a competitividade de grandes empresas”. Para tanto, foram estabelecidos quatro objetivos principais, a saber:

(1) Apresentar o entendimento de inovação e modelos de negócio a partir da percepção de especialistas que atuam em grandes organizações: abordado no item 4.1;

(2) Descrever como os especialistas conduzem a gestão de inovação e como esta se relaciona com o desenvolvimento de modelos de negócio nas grandes organizações: discutido no item 4.2;

(3) Identificar os tipos de inovação nos quais os especialistas que trabalham em grandes empresas estão envolvidos: enumerados no item 4.3;

(4) Identificar as motivações e barreiras enfrentadas na jornada de implantação da inovação voltada para o desenvolvimento de modelos de negócio: apresentadas no item 4.4 .

Constatou-se que a inovação é a base para o desenvolvimento de modelo de negócios ao proporcionar estrutura, processo, cultura e, principalmente, direcionamento estratégico voltado à continuidade da empresa e à competitividade, como pontuado por um dos entrevistados: “o planejamento estratégico é pautado mais de $70 \%$ por projetos de inovação, e, especificamente, um dos objetivos é associado à inovação e em associar inovação a modelo de negócio" [Entrevistado 4]. 
Assim, ter processo de inovação bem estabelecido é o primeiro passo para desenvolver modelo de negócios em grandes empresas.

Constatou-se também que, nas empresas pesquisadas, há alinhamento entre os conceitos teóricos e conhecimento dos entrevistados no que tange ao entendimento de inovação e aos modelos de negócios. No entanto, a prática, por meios dos exemplos citados pelos entrevistados, demonstra três fatores de como desenvolver modelo de negócios nas multinacionais investigadas, como apresentado na Figura 21.

Figura 21 - Fatores de modelo de negócios por meio da inovação

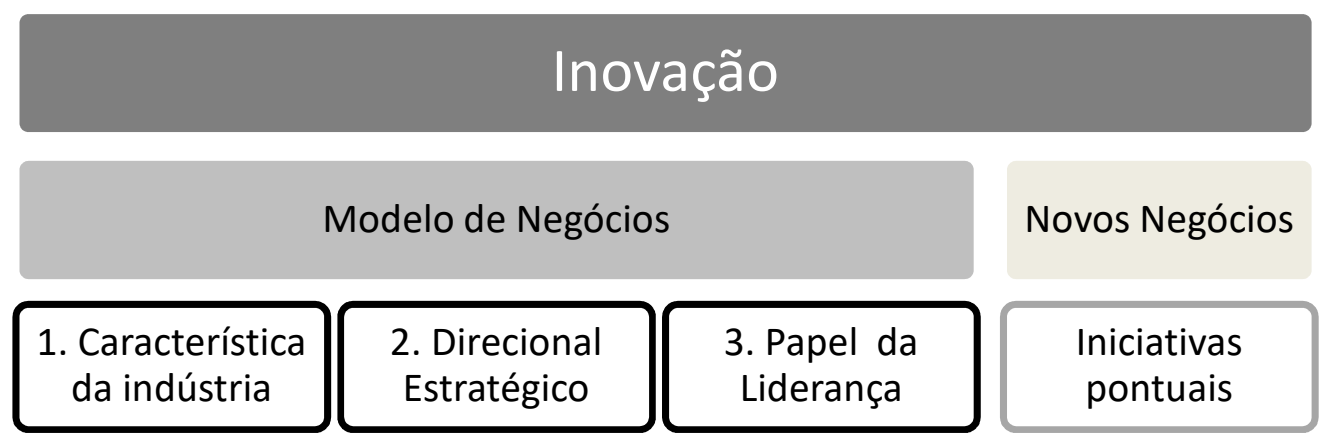

Fonte: Elaborado pela autora (2017).

A partir dos resultados obtidos, nota-se que o desenvolvimento de modelo de negócios por meio da inovação acontece de três formas distintas:

(1) devido à característica da indústria na qual os especialistas estão inseridos: empresas de setores classificados como inovadores de alta intensidade, segundo Little (2005), buscam modelo de negócios desde o início do processo de inovação.

(...) o modelo de negócio faz parte da inovação, assim como a inovação faz parte do programa estratégico. Existe muita integração, não tem tanta separação, toda vez que a gente faz uma inovação, existe a fase de modelo de negócio que agora é a primeira fase [Entrevistado 4].

(2) devido ao direcionamento estratégico da empresa em que os gestores atuam: quando a matriz define uma abordagem global para buscar novas fontes de receita.

(...) é como se a área de inovação não existisse nas regiões, ela é global, mas faz sim um link com os marketings regionais, mas ela tem algumas grandes prioridades globais, e são as prioridades globais que são definidas com base em fatores, e elas acontecem não necessariamente nos Estados Unidos, acontecem nos países onde estão as prioridades, mas isso hoje é um grande plano global, não é mais algo de inovações regionais [Entrevistado 6]. 
(3) devido ao perfil da liderança: por meio de empreendimentos locais liderados por pessoas com perfil mais empreendedor.

(...) No Brasil, a gente teve uma experiência bacana lá por 2010, 2011, que aí teve que se criar supervisão de modelos de negócios e que gerou uma empresa de serviço, então, criou uma empresa no Brasil de serviços que tem nos trazido uma experiência interessante de operar [Entrevistado 7].

Importante ressaltar que, para os especialistas que trabalham em empresas que estão em um estágio recente (cerca de três anos) de inovação, o desenvolvimento de modelos de negócios ainda não é tratado da forma como foi exposta por um dos entrevistados: "se a gente for, vamos dizer, repensar em modelo de negócio, a gente sabe fazer, por enquanto a gente não entrou, porque, como eu falei, existe um delay ainda" [Entrevistado 9].

Com base nesta pesquisa acredita-se que a inovação seja base para o desenvolvimento de modelo de negócios em grandes empresas. No entanto, a abordagem pode variar conforme a maturidade da empresa, a característica da indústria, o direcionamento estratégico ou o perfil da liderança reforçando estudos anteriores (LITTLE, 2005; RODRIGUEZ; DAHLMAN; SALMI, 2008; FURR; DYER, 2014). Importante destacar que mesmo com gestores que trabalham em empresas reconhecidas como inovadoras - cinco das nove empresas cujos gestores foram entrevistados fazem parte do grupo das premiadas por diferentes fontes, como mencionado -, alguns conceitos discutidos academicamente ainda não estão presentes na prática. Isto é constado no que se refere ao desenvolvimento de inovações como o conceito de lead users, de Von Hippel (2005) e de Veryzer (1998), por meio de protótipos para inovações radicais.

Dessa forma, segundo os respondentes deste estudo, as grandes empresas, que buscam desenvolver soluções fora do seu core business, necessitam tomar como ponto de partida o engajamento em prol da inovação para que haja um processo estruturado com patrocínio da liderança, alinhado com o direcional estratégico. Elas também necessitam considerar inovação além de produto, de processo ou incremental para que seja criado modelo de negócios. 


\subsection{LIMITAÇÕES E RECOMENDAÇÕES PARA ESTUDOS FUTUROS}

Apesar de ter havido critérios claros e objetivos - profissionais especialistas que trabalham com inovação ou modelos de negócios em cargos de liderança em grandes empresas multinacionais, para a seleção dos entrevistados houve limitações inerentes às pesquisas qualitativas, uma vez que dependem do entendimento do entrevistado a respeito do tema e da percepção e interpretação do pesquisador. Além disso, a dificuldade de contato com especialistas de empresas reconhecidas como inovadoras levou a ampliar a seleção dos sujeitos sociais para outras empresas que não figuraram no rol das premiadas.

Os diferentes canais de comunicação para a realização das entrevistas também pode ser um considerado um limitador do trabalho, uma vez que em entrevistas por telefone ou outro meio que não seja o presencial, o ambiente pode causar interferência ou mesmo dispersão por parte do entrevistado, levando a respostas indiretas ou pouco profundas.

Tais limitações inerentes ao trabalho são explicadas por decisões de escopo da pesquisa. Apesar dessas restrições, foi possível aprofundar o conhecimento sobre o processo de inovação em grandes empresas, assim como sobre o entendimento de alguns profissionais a respeito dos conceitos teóricos inerentes, compreendendo como a inovação tem papel fundamental para o desenvolvimento de modelos negócios em busca de uma melhor competitividade empresarial.

No entanto, cabe destacar que tais limitações podem eventualmente vir a ser suprimidas em estudos futuros, por exemplo, ao ser realizada uma pesquisa quantitativa com amostra representativa, para verificar a distribuição das grandes empresas multinacionais na abordagem para desenvolvimento de modelo de negócios, bem como em relação à maturidade de inovação nas organizações como alicerce para o desenvolvimento de novos modelos de negócios. 


\section{REFERÊNCIAS BIBLIOGRÁFICAS}

ABERNATHY, William J.; CLARK, Kim B. Innovation: Mapping the winds of creative destruction. Research Policy, v. 14, n. 1, p. 3-22, 1985.

ACCENTURE, 2015. US Innovation Survey: Clear vision, cloudy execution. Disponível em: $<$ https://www.accenture.com/us-en/insight-innovation-survey-clear-vision-cloudy-execution>. Acesso em: junho 2017.

ADNER, Ron. Match your innovation strategy to your innovation ecosystem. Harvard Business Review, R0604, p. 2-10, April 2006.

BANCO NACIONAL DE DESENVOLVIMENTO ECONÔMICO E SOCIAL (BNDES). Guia do Financiamento: quem pode ser cliente. Disponível em: <http://www.bndes.gov.br/wps/portal/site/home/financiamento/guia/quem-pode-ser-cliente/>. Acesso em: ago. 2017.

BAUER. Martin W.; GASKELL, George. Pesquisa qualitativa com texto, imagem e som: um manual prático. Rio de Janeiro: Vozes, 2002.

BIRKINSHAW, Julian; HAMEL, Gary. Management Innovation. Academy of Management Review, v. 39, n.4, p. 825-845, 2008.

BROWN, Tim. Design Thinking: uma metodologia poderosa para decretar o fim das velhas ideias. Rio de Janeiro: Elsevier, 2010.

CASADESUS-MASANELL, Ramon; RICART, Joan Enric. From strategy to business models and onto tactics. Long Range Planning, v. 43, n. 2, p. 195-215, 2010.

CHESBROUGH, Henry W. Open innovation: the new imperative for creating and profiting from technology. Boston: Harvard Business School Press, 2003a. $2003 \mathrm{~b}$.

The Era of Open Innovation. MIT Sloan management Review, v. 44, n. 3, p. 35-41,

Business Model Innovation: Opportunities and Barriers. Long Range Planning, v. 43, p. 354-363, 2010.

; ROSENBLOOM, Richard S. The role of the business model in capturing value from innovation: evidence from Xerox Corporation's technology spin-off companies. Industrial and Corporate Change, v. 11, n. 3, p. 529-555, 2002.

CHRISTENSEN, Clayton Magleby. The Innovator's Dilemma: the revolutionary book that will change the way you do business. New York: Harper Business, 2000.

O Crescimento pela Inovação: como crescer de forma sustentada e reinventar o sucesso. Rio de Janeiro: Elsevier, 2003. 
COTEC - Fundación Cotec para la Innovación Tecnológica. Pautas metodológicas de la gestión de la tecnología y de la innovación para empresas: Temaguide. Madri: Cotec, 1998.

COOPER, Robert G. Third-Generation New Product Processes. Journal of Product Innovation Management, v. 11, p. 3-14, 1994.

COOPER, Robert G.; KLEINSCHMIDT, Elko J. An investigation into the new product process: steps, deficiencies, and impact. Journal of Product Innovation Management, v. 3, n. 2, p. 71-85, 1986.

DAVILA, Tony; EPSTEIN, Marc J.; SHELTON, Robert. Making Innovation work: how to manage IT, and profit from IT. New Jersey: Wharton School Publishing, 2005.

DI SERIO, Luiz Carlos; VASCONCELLOS, Marcos Augusto de. Estratégia e Competitividade Empresarial: Inovação e criação de valor. São Paulo: Saraiva, 2009.

DRUCKER, Peter F. The Discipline of Innovation. Harvard Business Review, R0208, p. 510, Aug. 2002.

- Inovação e Espírito Empreendedor: prática e princípios. São Paulo: Cengage Learning, 2011.

DYER, Jeff; FURR, Nathan; LEFRANDT, Curtis. The Industries Plagued by the Most Uncertainty. Harvard Business Review, September 2014. Disponível em: $<$ https://hbr.org/2014/09/the-industries-plagued-by-the-most-uncertainty>. Acesso em: maio 2016.

EUCHNER, Jim; GANGULY, Abhijit. Business Model Innovation in Practice: A systematic approach to business model innovation can help capture value and reduce risks. ResearchTechnology Management, p. 33-39, nov.-dec.2014.

FRANKENBERGER, Karolin; WEIBLEN, Tobias; CSIK, Michaela; GASSMANN, Oliver. The 4I-frameworkof business model innovation: A structured view on process phases and challenges. International Journal of Product Development, v. 18, n. 3-4, p. 249-273, 2013.

FURR, Nathan; DYER, Jeff. The Innovator's Method: bringing the lean startup into your organization. Boston: Harvard Business Review Press, 2014.

JOHNSON, Mark W.; CHRISTENSEN, Clayton Magleby; KAGERMANN, Henning. Reinventing your business model. Harvard Business Review, v. 86, n. 12, p. 57-68, 2008.

JONASH, Ronald S.; SOMMERLATTE, Tom. O Valor da Inovação: como as empresas mais avançadas atingem alto desempenho e lucratividade. Rio de Janeiro: Campus, 2001.

KELLEY, Dona. Sustainable corporate entrepreneurship: evolving and connecting with the organization. Business Horizons, v. 54, p. 73-83, 2011.

KUEMMERLE, Walter. The Oxford Handbook of Entrepreneurship. New York: Oxford University Press Inc., 2006 
LITTLE, Arthur D. Innovation excellence: how companies use innovation to improve profitability and growth. Global Innovation Excellence Pres Dinner, February 2005.

MAGRETTA, Joan. Why business models matter. Harvard Business Review, v. 80, n. 5, p. 86-92, 2002.

MALHOTRA, Naresh K. Pesquisa de Marketing: foco na decisão. 3. ed. São Paulo: Pearson Hall, 2011.

MAZZON, José A. Formulação de um Modelo de Avaliação e Comparação de Modelos em Marketing. Dissertação (Mestrado em Administração). Faculdade de Economia, Administração e Contabilidade da Universidade de São Paulo, São Paulo, 1978.

MCKINSEY. The eight essentials of innovation. Mckinsey Quartely, April 2015. Disponível em: $\quad<$ https://www.mckinsey.com/business-functions/strategy-and-corporate-finance/ourinsights/the-eight-essentials-of-innovation>. Acesso em: junho 2017.

MINTZBERG, Henry; LAMPEL, Joseph B.; QUINN, James Brian; GHOSHAL, Sumantra. O Processo da Estratégia: conceitos, contextos e casos selecionados. 4. ed. Porto Alegre: Bookman, 2006.

ORGANIZAÇÃO PARA A COOPERAÇÃO E DESENVOLVIMENTO ECONÔMICO (OCDE). Manual de Oslo: diretrizes para coleta e interpretação de dados sobre inovação. 3. ed. FINEP, Brasília, 1997.

OSTERWALDER, Alexander. The business model ontology: a proposition in a design science approach.2004. 172 f. Tese (Doutorado em Ciência da Computação) - Université de Lausanne, Lausanne, 2004.

OSTERWALDER, Alexander; PIGNEUR, Yves. Business model generation: a handbook for visionaries, game changers, and challengers. New Jersey: John Wiley \& Sons, 2010.

PHAN, Phillip. H.; WRIGHT, Mike; UCBASARAN, Deniz; TAN, Wee Liang. Corporate entrepreneurship: Current research and future directions. Journal of Business Venturing, v. 24, n. 3, p. 197-205, 2009.

PORTER, Michel. Competição: Estratégias Competitivas Essenciais. 2. ed. Rio de Janeiro: Campus, 1999.

RIES, Eric. The lean startup: How today's entrepreneurs use continuous innovation to create radically successful businesses. New York: Crown Books, 2011.

RODRIGUEZ, Alberto; DAHLMAN, Carl; SALMI, Jamil. Conhecimento e inovação para a competitividade. Tradução: Confederação Nacional da Indústria. Brasília: CNI; Banco Mundial, 2008.

SAMPIERI, Roberto Hernandez; COLLADO, Carlos Fernández; LUCIO, Maria del Pilar Baptista. Metodologia de Pesquisa. 3. ed. São Paulo: McGraw-Hill, 2006. 
SCHUMPETER, Joseph Alois. A Teoria do Desenvolvimento Econômico. São Paulo: Nova Cultural, 1997.

SEDDON, Peter; LEWIS, Geoffrey. Strategy and Business Models: What's the Difference? PACIS. Proceedings, p. 17, 2003.

SELLTIZ, Claire; JAHODA, Marie; DEUTSCH, Morton; COOK, Stuart W. Métodos de pesquisa nas relações sociais. 3. Reimpressão. São Paulo: E.P.U., Editora da Universidade de São Paulo, 1974.

SLYWOTZKY, Adrian J.; MORRISON, David J. The Profit Zone: How strategic business design will lead you to tomorrow's profits. New York: Three Rivers Press, 1998.

STEFANOVITZ, Juliano Pavanelli. Contribuições ao Estudo da Gestão da Inovação: proposição conceitual e estudos de caso. 2011. 197 f. Tese (Doutorado em Engenharia de Produção) - Escola de Engenharia de São Carlos da Universidade de São Paulo, São Carlos, SP, 2011.

TEECE, David John. Business Models: Business Strategy and Innovation. Long Range Planning, v. 43, p. 172-194, 2010.

TELLES, Renato. A efetividade da matriz de amarração de Mazzon nas pesquisas em Administração. Revista de Administração da Universidade de São Paulo, São Paulo, v. 36, n. 4, p. 64-72, 2001.

TIDD, Joe; BESSANT, John; PAVITT, Keith. Gestão da Inovação. 3. ed. Porto Alegre: Bookman, 2008.

TIMMERS, Paul. Business models for electronic markets. Electronic Markets, v. 8, n. 2, p. 38, 1998.

UNITED NATIONS. Multinational corporations in world development. New York: Department of Economics and Social Affairs, 1973.

VERYZER, Robert W. Discontinuous innovation and the new product development process. Journal of Product Innovation Management, v. 15, n. 4, p. 304-321, 1998.

VON HIPPEL, Eric. Democratizing Innovation. Cambridge, MA: The MIT Press, 2005.

; OGAWA, Susumu; DE JONG, Jeroen P. J. The age of the consumer-innovator. MIT Sloan Management Review, v. 53, n. 1, p. 27, 2011.

YIP, George S. Using strategy to change your business model. Business Strategy Review, v. 15 , n. 2, p. 17-27, 2004.

ZOTT, Christoph; AMIT, Raphael. Business model design: an activity system perspective. Long Range Planning, v. 43, n. 2, p. 216-226, 2010. 


\section{APÊNDICE: ROTEIRO DA PESQUISA QUALITATIVA}

\section{Roteiro}

O presente estudo tem como objetivo principal entender como a inovação por meio do desenvolvimento de modelo de negócios contribui para a competitividade de grandes empresas. Dessa forma, serão abordadas algumas questões divididas em quatro blocos, visando a coletar dados e informações que serão analisados posteriormente à luz das teorias de inovação e de modelo de negócios.

Antes de iniciar as questões para o estudo, gostaria de solicitar permissão para gravar a nossa conversa. Essa gravação será utilizada posteriormente apenas para facilitar a análise dos resultados e não será compartilhada com outras pessoas além de mim e da orientadora do presente estudo.

\section{Perfil do Entrevistado}

Poderia começar contando-me um pouco sobre:

1. Sua Formação;

2. Seu tempo de empresa e cargo;

3. Seu tempo dedicado à inovação.

A partir de então, vamos passar para as perguntas relacionadas ao tema do estudo.

\section{Bloco 1 - Entendimento de inovação e modelos de negócios a partir da percepção de especialistas que atuam em grandes organizações.}

1. Como você define inovação? Qual a definição de inovação para a sua empresa?

2. Como você define modelo de negócios? Qual a definição de modelo de negócios para a sua empresa?

3. Qual a importância desses dois temas - inovação e modelo de negócios - para a empresa?

4. Há quanto tempo a empresa está engajada nesses temas? 
Houve alguma mudança no entendimento de inovação nos últimos anos? Como foi esse processo?

\section{Bloco 2 - Identificação dos tipos de inovação nos quais os especialistas que trabalham em grandes organizações estão envolvidos.}

1. Quais inovações são desenvolvidas na empresa?

- Explorar exemplos em Produto, Processo, Marketing / Comunicação, Organizacional.

- Explorar exemplos de inovação incremental.

2. Alguma das inovações citadas poderia ser entendida como radical, ao gerar uma mudança significativa que afetou o modelo de negócios e a tecnologia da empresa?

3. Alguma das inovações citadas poderia ser entendida como disruptiva / revolucionária ao trazer ao mercado uma proposta muito diferente da existente $\mathrm{OU}$ tornando obsoleta a competência estabelecida?

4. Quais inovações aumentaram a competitividade?

5. Quais inovações criaram modelos de negócios?

6. Qual é a inovação de maior destaque na sua opinião? E na percepção da empresa?

Bloco 3 - Descrição de como os especialistas conduzem a gestão de inovação e como esta se relaciona com o desenvolvimento de modelos de negócios nas grandes.

1. Qual a diretriz estratégica da empresa? Inovação faz parte? E os modelos de negócios?

2. Há um modelo/metodologia de inovação da empresa?

[SE SIM]: Comente como isso vem sendo realizado?

[SE NÃO]: Justifique o porquê de ainda não ter sido adotado?

3. Há um processo estabelecido para desenvolver modelo de negócios?

[SE SIM]: Comente como isso tem sido feito?

[SE NÃO]: Justifique o porquê de ainda não ter sido adotado?

4. Como é o processo? Quais são os principais elementos e atividades?

5. Quem participa do processo? Há colaboradores (agentes) internos? E externos?

6. Como o processo está inserido no dia a dia da empresa? 
7. Existe uma área responsável por liderá-lo?

8. Qual o seu papel nesse processo? E qual o papel de sua equipe nesse processo? Qual autonomia existe nesse processo?

\section{Bloco 4 - Identificação de motivações e barreiras}

1. O que move a inovação na empresa na qual você trabalha?

2. Como a empresa motiva os colaboradores para participarem ativamente do desenvolvimento de inovações?

3. Quais motivações existem hoje para inovar buscando o desenvolvimento de novo modelo de negócios?

4. Quais barreiras existem hoje para inovar buscando o desenvolvimento de novo modelo de negócios?

5. Qual o papel da liderança para motivar e para eliminar barreiras? 